\title{
RACIAL-ANATOMICAL STUDDIES ON THE LARYNX IN KYUSHU JAPANESE
}

\author{
By
}

K. MASUYAMA

Dept. of O.R.L. Kumamoto University, Medical School

Systematic studies on the larynx in Kyushu Japanese ( $\delta 30,+\circ 20$ ) and comparison with other races were made and the following results were obtained.

1. Laryngeal cartilages: The maximal diameter of the larynx and the size of each part of the thyroid cartilage were, larger in the males than in the females except the degree of inclination of the superior cornu, anterior angle of the thyroid cartilage and the angle of the inferior thyroidt notch, in general, these were smaller than those of the European, about equal or somewhat smaller than those of the Chinese and about equal to those of the Japanese (OZEKI) from other districts. The sizes of each part of the cricoid cartilage and the arytenoid cartilage, of the male were also larger than those of the female. The size of the cricoid cartilage of the male and the female were somewhat larger than that of the Japanese (OZEKI) from other districts and of the aborigins of Formosa, and in the male it was smaller than that of the Chinese.

2. Ossiflcation of laryngeal cartilages: The degree of ossification in each cartilage showed a definite order and type being parallel to the age. Only thyroid cartilage showed remarkable sexual difference. In the evalution of the ossification phenomenon, X-ray study was somewhat superior than Gross examination.

3. Laryngeal muscles: Study of cricothyroid muscles showed the diastasis type in the majority of the cases as aeen among other races, the incidence being somewhat smaller that of the European. and larger than that of the Chinese. In both sexes, in a majority of the cases, the study of thyroarytenoid muscles showed horizontal type, whereas the vertical type was common among the European and the Chinese. The attahement of the thyro-arytenoid muscle and the arytenoid muscle wasfound in the highest rate ( $96 \%$ ) among the people of Kyushu district,

4. Laryngeal cavity: The size of each part of the laryngeal cavity was found smaller in both sexes than that of the European in general and in the male somewhat smaller than that of the Chinese. In sexual distinction the male was superior to the female as in the cases of the European. and the Japanese from other dirtricts. In respect to the location of the small sack of larynx an. half or a majority of the people oi Kyushu district and the Chinese also had it in the middle and. very seldom in the rear in both sexes while the Japanese (OZEKI) from other districts had it in the rear and the negroes and the European in the front. 


\title{
九州日本人喉頭の人種解剖学的研究
}

\author{
熊本大学医学部第二解 剖 学教 等 (主任 : 忽那將聚教授) \\ 熊本大学医学部耳學咽喉科学教室 (主任: 野坂保次教授)

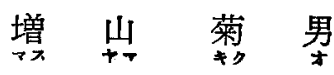 \\ 第 1 報 唤頭軟骨に就いて \\ 目次 \\ 第 2 報 喉頭軟骨化骨に就いて \\ 第了報 喉頭筋に就いて \\ 第 4 報 喉頭腔に就いて
}

第 1 報 䐅頭軟骨に就いて

\section{緒 言}

人種解剖学的見地より㬋頭を系統的に調查した報告は 皦なく，中でも㬋頭軟骨に就いての計則的研究は余り行 务れていない。

我ぶ国に括いては尾笑 (1911)，(1912）が日本人の甲 状軟骨，輪状軟骨に就いて調查し，男女の差美は勿論白 人との比較を行い，又佐山（1931）は支那人成年男子の 皖頭に就いて研究し他人種と較べ，次いで丸山（1935） は台湾蕃人の咲頭を調查し，日本人，支那人，欧洲人之 夫々比較対照している・その後松島 (1939) は気管・気 管支鏡稀查上必要な㬋頭・気管及び気管支の解部学的不 究を行い，気道の一部としての喉頭軟骨の 1 2 の部分 を調查研究している。

このよらに日本人の㬋頭軟骨に就いての研究は尾閔唯 一人の感あり，しかも余り系統的に行われていない。

そこで筆者は九州出身の成人に就いて調查し，これ等 の諸成績を欧洲人，ェルザス人，支那人，台湾蕃人及び 他地方出身の日本人の成績と比較検討した。

\section{1. 研究材料並びに研究方法}

研究材料:

本矿究に使用した材料は，すべて熊本大学医学部解剖 学教室に和いて解剖実習に供せられた九州出身の成人男 30 例，女 20 例，計 50 例であつて，10\% Formalin 液 にて固定した硬化屍より得たものである（但し呼吸器疾 患殊に肺結核死亡中喉頭に変化のあるるのはすべてこれ を除外した)・これを年令別並びに性別に分類すると， 第 1 に示す通りである。

研究方法:

形状前びに大きさ, 距離, 角度等は尺度, 分度器等を 用いて計测した・即ら甲状軟骨においては甲状軟骨を輪

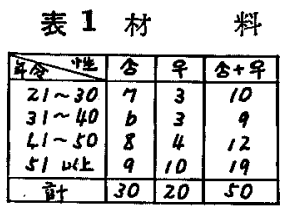

状軟咼，その他筋等より分離せず，直接計測できる部分 に就いては自然の位置に括いて，その他の部分ではでき る文㳄骨を損傷乃至は変形させないように除去したもの に就いて計測した・輪状軟骨に括いても同様甲状軟骨;， 披裂軟骨，その他柔軟部を除去したるのに就いて直接計 測を行い，殊に関節面の計測及び観察には細心の注意を 払つた・披裂軟鬲は剔出したものに就いてこれを行い， その他の諸軟骨の調㚗も併せて行った。

攵先人の成績と比較するに当つては性別的に比較した が，筆者によつては男女集計した成績を用いた人もあ り，このような場合は筆者も男女合計の成績を以て比 較した・な特調查した項目は次の如くである。

1. 甲状軟骨

A. 計測部位

1）前縁の高さ：上甲状切痕底より正中線炕执いて甲 状較骨下縁迄の距離.

2）上角の長さ：甲状顿骨上縁と上角の移行部より上 角尖端迄の距離 (内面計測) .

3）上角の傾斜度：甲状軟骨上緑と上角とのなす角 度.

4）下角の長さ：甲状軟䯚下縁と下角との移行部より 下角尖端迄の距離 (内面計測).

5）軟骨板の幅：甲状軟骨上粶及び下縁に括注る幅に 分けた。

i）上縁の幅；甲状軟骨:上縁の延長線と後猭の交叉 
点と，上甲状切痕底との距離・

ii）下縁の幅；甲状軟肯·下緑正中点より下緑に沿 つて軟骨板の後緑迄の距離。

6）後緑の長さ：甲状軟骨後縁が甲状顿冎・上・下縁の 延長線之と交必する出点問の距離。

7）軟骨板の高さ：甲状軟骨板を前・後部の両部に分 けた・

i）前部の高さ；甲状軟罥後縁に平行な直線上にお ケる上甲状切痕側部の上縁最高点と下縁間の距離.

ii）後部の高さ； 上角と下角の 基部相互間の距離.

8) 甲状軟盈前角度：左右の両甲状軟骨板が合して作 る角度.

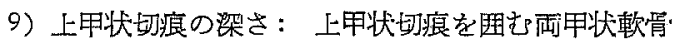
上縁の最高点を結ぶ直線と上甲状切痕底との最短距離．

10）上甲状切痕の角：上甲状切痕を 因む両甲状軟肯: 板のなす角・

11）甲状軟骨横径：場所により5つの部位に分けた。

i）上口横径；上角発出部に批ける両側甲状軟骨:上 緑間の距離 (内面計測).

ii）上縁最大横赁；両側甲状軟骨:上縁問の最大距 離 (外面計測)

iii）上甲状結節間距離；左右上甲状結節最突出部 間距離.

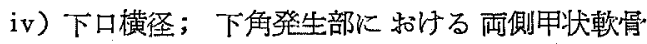
下緑間の距離 (内面計測)。

v）下緑最大検径；両側下苦基部に打㚈る距離（外 面計測).

12）甲状軟胥前後俻：最大と最小前後径に分けた・

i）最大前後贷； 甲状軟骨最前突出点より甲状軟学 徬縁を含む平面への垂直距離。

ii）最小前後径；甲状軟骨下緑正中より甲状軟㸗 後縁を含む平面への垂直距離.

13）㗹頭全高：正常位（喉頭の正常位とは輪状軟甹" 下縁を以て水平に且つ輪状軟骨板部の中線が垂直にある ような位置）に置いた㬋頭軟骨に就いて，甲状軟骨”上縁 最高部より輪状軟至・下緑迄（側部）及び上甲状切痕底上 り輪状軟盈一縁迄 (中央部) の垂直距離。

B. 甲状軟骨深広示標甲奖軟胃最大前後径 $\times 100$

C. 甲状軟骨·孔 甲状軟瓷”最大横膲

D. 左右失衡

E. 麦粒小体

2. 輪状軟骨。
A. 計 测部 位

1）上口径：矢状径と検径にに分けた。

i）矢状柊；輪状軟晤·上縁中吹と弓上縁中央間の距 離.

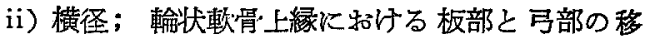
行部，即ち環部の側部上縁中央間の距離・

2）下口径：矢状径と横径に分けた。

i）矢状径：鐱状軟县板部之弓部の下縁正中間の距 離.

ii）横径；鐱状軟肯、下緑に特ける板部と弓部の移 行部，即ち環部の側部下縁中央間の距離.

3）弓高径：輸伏軟骨·部の正中に扎ける高さ・

4）板中央高径：輸状軟胃板部中央に和ける高さ・

5）披裂関節面内端より下縁迄の距離 (板の高さ)：下 緑迄の垂直距離.

6）披裂関節面外端より下縁迄の距離：下縁迄の垂直 距鹤.

7）最大横径：両側甲状関節面間の距離.

8）披裂関節面内端間距離：

9）披裂関節面外端間距離（板上部の広径）:

10）周径： 輸状軟骬環部中央，甲状関節面の下部, 板部下緑附近に和ける周径。

11）披裂関節面：縱径と横径に分けた・

i) 縱径; 両極間の距離.

ii）横径；長軸の中央でこれに直角に交る 両緑間 の距離.

12）甲状関節面： 縱径と横径に分けた。

i) 縱 径

ii) 横 径

B. 披裂関節面形態

C. 甲状関節面

D. 輪状軟肯板部形状

1）示標：広々示標と高広示標に分けた。

i）広々示標： $\frac{\text { 板上部の広佳 } \times 100}{\text { 最大横堂 }}$

ii）高広示標； $\frac{\text { 板上部の広径 } \times 100}{\text { 板の高窐 }}$

2）輸状顿骨板上下縁:

E. 輸状軟蛋と気管輪との癒着

3. 披裂軟胥。

A. 計 测部 位

1）技裂軟贵高径：披裂軟骨輪状関節面中央より小角。 軟骨”老除した尖端迄の距離. 
2）輪状関節面：縦径と横径に分林た。

\section{B. 輸状関節面柇態}

A. その他の諸軟盗"

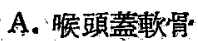
B. 小角軟骨
C. 楔状軟骨

\section{II. 成績と比較}

1. 甲状軟冝

1) 甲状軟盈計測值

九州日本人における甲状軟監各部位の計測值は表 2 の 如くである.

表 2 妇状軟留暗測值 (単位 $\mathrm{mm},{ }^{\circ}$ )

\begin{tabular}{|c|c|c|c|c|c|c|c|c|c|c|c|}
\hline \multirow{2}{*}{\multicolumn{3}{|c|}{ 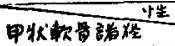 }} & \multicolumn{4}{|c|}{5} & \multicolumn{4}{|c|}{ 우 } & \multirow{2}{*}{ 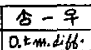 } \\
\hline & & & $m$ & $M \pm m$ & $\sigma$ & V & $n$ & $M \pm m$ & $\sigma$ & $v$ & \\
\hline \multicolumn{3}{|c|}{ 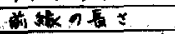 } & 30 & $176 \pm 0.32$ & .76 & 1000 & 20 & $12.6 \pm 0.14$ & 0.85 & 645 & $50 \leq 0,17$ \\
\hline \multirow{2}{*}{\multicolumn{3}{|c|}{ 上のの長ミ 原 }} & 30 & $142 \pm 0.61$ & 236 & 23.66 & 20 & $11.8 \pm 0.36$ & 1.63 & $|3 \pi|$ & $2.4 \times 0.71$ \\
\hline & & & 30 & $146=0.61$ & 3.36 & 23,01 & 20 & $123 * 0.52$ & 2.30 & $18+70$ & $2,3 \times 0.80$ \\
\hline \multirow{2}{*}{\multicolumn{3}{|c|}{ 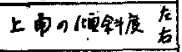 }} & 30 & $9235 \times 272$ & $|1400|$ & 15,94 & 20 & $100.0 \div 2.92$ & (3.2.23 & 12,23 & $-6.5 \div 40.03$ \\
\hline & & & 30 & $95.8 \pm 268$ & {$[1466]$} & 1530 & 20 & $98.0: 2.70$ & 1208 & 12.33 & $-2 z \times 3.81$ \\
\hline \multirow{2}{*}{\multicolumn{3}{|c|}{ Fゆの表、告 }} & 30 & $a 0 \pm 0.16$ & 089 & 1483 & 20 & $5,0 \pm 0.19$ & 0.24 & 16.80 & $1.0 \pm 0.28$ \\
\hline & & & 30 & $42 \pm 0.21$ & 1.15 & 1855 & 20 & $5 . Z=0.1 \pi$ & 0.82 & 15.77 & $10 \div a .28$ \\
\hline \multirow{4}{*}{ 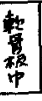 } & \multirow{2}{*}{\multicolumn{2}{|c|}{ 上㧡os $\frac{\hbar}{6}$}} & 30 & $41.3 \times 0.54$ & 297 & $7 / 9$ & 20 & toult & 199 & 6.75 & $11.8 * 0.70$ \\
\hline & & & 30 & $41.6=0.54$ & 293 & 704 & 20 & $29.2 \times 0.43$ & 1.93 & 661 & $124 \pm 0.69$ \\
\hline & \multirow{2}{*}{\multicolumn{2}{|c|}{ 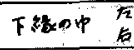 }} & 30 & $=4,32$ & 1.77 & HeS & 20 & $27.2 * 0.30$ & 1.35 & 5.22 & $5.9 \div 0.44$ \\
\hline & & & 30 & $30.7 \div 0.27$ & 1.45 & .422 & 20 & $235 \div 0.30$ & 1.32 & 5.62 & $2.2 \pm 0.40$ \\
\hline \multirow{2}{*}{\multicolumn{3}{|c|}{ 视统の長 }} & 30 & $222 \pm 0.54$ & 2.05 & 13.29 & 20 & $1,1,2=0.39$ & 1.74 & 10.74 & 0.67 \\
\hline \multirow{4}{*}{ 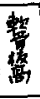 } & & & 30 & $\begin{array}{l}21.5 * 0.40 \\
269 \pm 0.30\end{array}$ & $\begin{array}{r}2.20 \\
1.43\end{array}$ & $\begin{array}{r}1023 \\
600\end{array}$ & $\begin{array}{l}20 \\
20\end{array}$ & $\begin{array}{r}15.0 \pm 0.36 \\
19.4\end{array}$ & $\begin{array}{l}1.60 \\
1.20\end{array}$ & $\begin{array}{r}10.67 \\
6.19\end{array}$ & $\begin{array}{l}6.5 \pm 0.54 \\
5.5 \pm 0.44\end{array}$ \\
\hline & \multicolumn{2}{|c|}{ 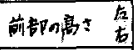 } & 30 & $244 \pm 0.41$ & 225 & 9.22 & 20 & $14.3 \pm 0.21$ & 0.94 & 4.87 & $51=0.46$ \\
\hline & \multirow{2}{*}{\multicolumn{2}{|c|}{ 独那旸: }} & 30 & $23.0=0.44$ & 2.40 & 10.43 & 20 & $17.1 \pm 0,37$ & 1.66 & $9.7 I$ & $5.9 \div 0.5 \pi$ \\
\hline & & & 30 & $229 \div 0.34$ & 1.24 & 803 & 20 & $165=0.36$ & 1,63 & 9.88 & $64 \times 0.50$ \\
\hline \multirow{2}{*}{\multicolumn{3}{|c|}{ 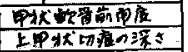 }} & 30 & $724: 237$ & 1296 & 17.73 & 20 & $83.8 \div 3.52$ & 15,72 & 1230 & $\mid-6.1=4.24$ \\
\hline & & & 30 & $.44: 044$ & 2.39 & 2543 & 20 & $7 ! 1 \neq 0.2 x$ & 6.24 & 17.46 & $2.3 \pm 0.52$ \\
\hline \multicolumn{3}{|c|}{ 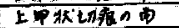 } & 30 & $47.7 \pm 3.18$ & 77.35 & 3437 & 20 & $58.5 \times 3.45$ & 15.43 & 2638 & $-10.8 \pm 469$ \\
\hline \multirow{5}{*}{ 棈 } & & 7ex & 30 & $40.6=0.70$ & 321 & $63 x$ & 20 & $33.6 \neq 0.42$ & 188 & 5,60 & $3.0 \pm 0.22$ \\
\hline & & & 30 & $43.5 \times 0.75$ & 4.14 & 952 & 20 & $363=0.43$ & 1.93 & 5.32 & $72 \times 0.86$ \\
\hline & & (phin) & 30 & $4555 * 0.74$ & 405 & 2.90 & 20 & $375 \div 944$ & .1.96 & $5: 21$ & $60=0.86$ \\
\hline & & & 30 & $307 \pm 0.35$ & 192 & 6,25 & 20 & $242=0,31$ & 1.60 & 579 & $6.5 \div 0.47$ \\
\hline & & & 30 & \pm 0.37 & 2.01 & 6.00 & 20 & $27.1 \times 0.29$ & 1.30 & 4.0 & $0.4 \pm 0.47$ \\
\hline \multirow{2}{*}{\multicolumn{2}{|c|}{ 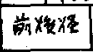 }} & $k$ & 30 & $37.7 \div 051$ & 280 & $\pi 43$ & 20 & $277=0.49$ & 2.20 & 714 & $10.0=0.71$ \\
\hline & & 3 & 30 & $2 k 4=0.35$ & 1.92 & 727 & 20 & $20.1 * 0.26$ & $a / b$ & 5.27 & $6.3 \leq 2.44$ \\
\hline \multirow{2}{*}{\multicolumn{3}{|c|}{ 化㬓全高 }} & 30 & $440 \leq 0.40$ & 2.20 & 500 & 20 & $33.9 \div 0.39$ & i.73 & 510 & $10.1 \pm 0.56$ \\
\hline & & & 30 & $\begin{array}{l}32.5=0,54 \\
422 \pm 0.50\end{array}$ & $\begin{array}{l}298 \\
272\end{array} \mid$ & $\begin{array}{l}9.17 \\
6.45\end{array}$ & 20 & $\begin{array}{l}26.5 * 0.38 \\
33.0 * 0.41\end{array}$ & $\begin{array}{l}1.69 \\
182\end{array}$ & $\begin{array}{l}6,3 \pi \\
5,52\end{array}$ & $\begin{array}{l}4.0 \times 0.66 \\
9.2 \pm 0.65\end{array}$ \\
\hline
\end{tabular}

即ち上角の傾斜度，甲状軟骨前角度，上甲状切痕の角 に和いては女性は男性より見掛上大で，その他の部位で はすべて男性が女性より大である・中でも前縁の長さ，

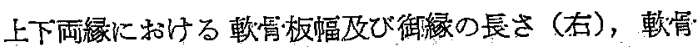
板前後部の高径, 下口横径, 下縁最大横径, 前後径, 㬋 頭全高 (側部) に拉いて有意な差異を示し，男女共左右 計測値間には殆んど差異を認めない。

\section{2) 甲状軟冾深広示標}

表了に示すよらに; 男性は69〜105 (87.1土1.86)，女 性は 65〜88 (81,6士1.00) で男性の方が大である・この 梁広示標は甲状軟骨前角度の大小関保し，即ち示標の 大小は角度の大小に反比例するむのであり，男性が女性 より大きいのは男性の甲状軟骨前角度が小さい事を袁わ している.

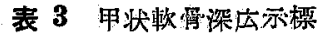

\begin{tabular}{|c|c|c|c|c|c|}
\hline 栍 & $M * m$ & $\sigma$ & $v$ & $\max$ & $\min$ \\
\hline \begin{tabular}{|l|l|}
$\begin{array}{l}0 \\
8\end{array}$ & 30 \\
\end{tabular} & $\begin{array}{l}87.111 .86 \\
91.6=1.00\end{array}$ & $\begin{array}{l}1020 \\
451\end{array}$ & $\begin{array}{c}11.71 \\
5.53\end{array}$ & $\begin{array}{c}105 \\
88 \\
88\end{array}$ & $\begin{array}{l}69 \\
65\end{array}$ \\
\hline
\end{tabular}

3) 甲状軟骨孔

表 4 亿示すように男女 50 例中 $18(36.0 \% \pm 679 \%)$ 飞 物いて認められ，性別的には出現率に殆んぞ大差なく，更 に側別では男性は右側のみに出現するものが 7 例 (23.3 $\% \pm 7.72 \%)$ で最も多く，女性は而側にあるすの 4 例 (20.0\%土8.94\%) で最む多く，従つて一定した側別関保: は見出せない。

表 4 甲状軟骨·孔側别

\begin{tabular}{|c|c|c|c|c|c|}
\hline \multirow{2}{*}{ 㑭别 } & \multicolumn{2}{|r|}{ 䂞 } & \multicolumn{2}{|r|}{ 车 } & $6+9$ \\
\hline & 30 & $\%$ & 20 & $\%$ & $50 . \%$ \\
\hline$\frac{1}{2}\left|Q_{1}\right|$ & 3 & $100 \pm 5,48$ & 3 & $15,0 \pm 799$ & $12.0 \times 4460$ \\
\hline 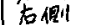 & 7 & $23.3 \pm 7.72$ & 0 & & $14,0=401$ \\
\hline 勾经1 & 11 & $3.3 \pm 326$ & 4 & $20,0 \pm 894$ & $10.0=424$ \\
\hline 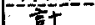 & 7 & $\overline{3} \bar{b} \overline{7}=\overline{8} \overline{8} 0$ & $\overline{7}$ & $35,0 \pm 10,67$ & $340=6.79$ \\
\hline
\end{tabular}

甲状軟量·孔の出現部位を上甲状結節を基淮とした 場合，表 5 に示村ように，男女共に上甲状粘節前下 部に出現するものが最も多い。

表 5 甲状軟骨孔出現部位 (上丑状

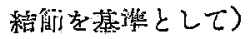

\begin{tabular}{|c|c|c|c|c|c|c|}
\hline$\approx$ & 应主 & & 否 & & q & $6+4$ \\
\hline 部 & & 12 & $\%$ & 11 & $\%$ & $23 \%$ \\
\hline$F$ & 满F部 & 9 & $\begin{array}{r}75.0: 12.50 \\
8.3 \pm 7.96\end{array}$ & ? & $\begin{array}{r}11.8+11.63 \\
9.1+267\end{array}$ & $\begin{array}{cc}18 & 78.3 \pm 8.60 \\
2 & 8.7=5.88\end{array}$ \\
\hline & tot & 10 & $733 \pm 10.77$ & 10 & $90.9+8.67$ & $87.0 \div 701$ \\
\hline & & 2 & $16.7 \pm 10.77$ & $\begin{array}{l}1 \\
0\end{array}$ & $9.1 \times 8.67$ & $\begin{array}{ll}3 & 13,0 \pm 701 \\
0 & \end{array}$ \\
\hline
\end{tabular}

㕛形状は表6に示すように円形又は㮠円形を示 し，男性にては円形と楕円形とは大体類似の出現頻 度を示すが，女性にてはすべて円形で楕円形は㫮無 である・大きさは円形のものでは男性は直埾 $1 \mathrm{~mm}$ より $4 \mathrm{~mm}$ の間にあり，女性は直径 $1 \mathrm{~mm}$ 上り $3 \mathrm{~mm}$ で，棈円形のものでは男性注長定 $3 \mathrm{~mm}$ 以上 $4 \mathrm{~mm}$, 短 堡 $1.5 \mathrm{~mm}$ 以上 $2.5 \mathrm{~mm}$ であり,この中でる長径 $4 \mathrm{~mm}$ 短堡 $2 \mathrm{~mm}$ の子のが多く各々 4 例壱認めた・方向は長 径が甲状軟骨上縁代平行なるのが 1 例，他の 6 例は長径 が前上方より後下方に闶つていた。

表 6 甲状軟骨孔形状

\begin{tabular}{|c|c|c|c|c|c|}
\hline \multirow{2}{*}{\multicolumn{2}{|c|}{$x^{2}+x^{2} \frac{12}{20}$}} & \multicolumn{2}{|r|}{ 右 } & 9 & $6+9$ \\
\hline & & 12 & $\%$ & $\%$ & $23 \%$ \\
\hline म & $\frac{\sqrt{1}}{\sqrt{6}}$ & $\begin{array}{l}3 \\
2\end{array}$ & $\begin{array}{l}25,0 \pm 12.50 \\
147=1077\end{array}$ & $\begin{array}{ll}7 & 63.6 \pm 1451 \\
4 & 33.321421\end{array}$ & $\begin{array}{rl}10 & 43.5 \\
6 & 26.1\end{array}$ \\
\hline$H^{2}$ & 鼓 & 5 & 44.721423 & $111000 \times 0$ & $16 \quad 69.6=9.59$ \\
\hline 楊 & 店 & $\begin{array}{l}t \\
b\end{array}$ & $\begin{array}{r}83 \pm 296 \\
600 \pm 1443\end{array}$ & $\begin{array}{l}0 \\
0\end{array}$ & $\begin{array}{lr}1 & 43: 423 \\
b & 2 b_{1}:=9.16\end{array}$ \\
\hline fis, & है & 7 & $58,3=1423$ & $\overline{0}$ & $30.4+9.59$ \\
\hline
\end{tabular}

4) 左右失衡

甲状軟冎各部の計測に和いては左右に著しい羑異を認. 
めないが，左右両板の角度，傾斜相互関倸に括いてのみ 諗められた。

\section{5) 麦粒小体}

これは甲状顿骨上角又は舌骨大角の揬断库物と見做さ れるもので，その出現率は表７に示すように，32例 (64.0\%土6.79\%) 㒛められ，男女共両側に存するもの が多い.

表 7 麦 粒小体

\begin{tabular}{|c|c|c|c|c|c|c|}
\hline & \multicolumn{2}{|r|}{$\delta$} & \multicolumn{2}{|r|}{9} & \multicolumn{2}{|r|}{ 항ㅇ } \\
\hline & 30 & $\%$ & 20 & $\%$ & 50 & $\%$ \\
\hline 禹 㑬 & 14 & $46.7 \pm 4.11$ & 9 & $45,0 \leqslant 1114$ & 23 & $46,0 \pm 7,05$ \\
\hline 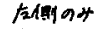 & 3 & $10,0 \pm 5,48$ & $z$ & $10.0+6.71$ & 5 & $100 \div 424$ \\
\hline F假口兵 & 0 & & 4 & $20,0 \pm \geq 94$ & 4 & $\{8=3, X 3$ \\
\hline$\overline{y t}^{-\infty}$ & 17 & $56.7 \pm 9.04$ & is & $350 \pm 9.68$ & $3 \overline{2}$ & $640+6.79$ \\
\hline
\end{tabular}

2. 輪状軟霄

1) 輸状軟婴計测值

輪状軟骨各部の大きさは表 8 亿示寸如くである・即ち すべての部位に括いて男性が女性より大で，特に上口矢 状径及び横径，披裂関節面内端より下緣迄の距䴤（右）， 最大横徍，披裂関節面外端間距離及び周径において有意 の美異を示し，男女共左右計測値間には殆えど羑異を認 めないが，甲状関節面絿径及び横径に括いて女性にのみ 見掛上左側よりも右側が小である。

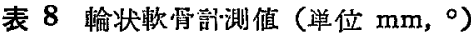

\begin{tabular}{|c|c|c|c|c|c|c|c|c|c|c|}
\hline \multirow{2}{*}{\multicolumn{2}{|c|}{ 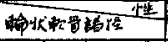 }} & \multicolumn{4}{|c|}{6} & \multicolumn{4}{|c|}{ 年 } & \multirow{2}{*}{$\frac{s-q}{a+m}$} \\
\hline & & & $\pm m$ & & 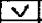 & $n$ & & $\sigma$ & & \\
\hline \multicolumn{2}{|r|}{$74 \times 18$} & 30 & $\begin{array}{l}225 \% 0,30 \\
20,4 \pm 031\end{array}$ & $\begin{array}{l}1.68 \\
1.69\end{array}$ & $\begin{array}{l}5.51 \\
5.2 \mathrm{x}\end{array}$ & $\begin{array}{l}20 \\
20\end{array}$ & $\begin{array}{l}244 \pm a^{2} 2 \\
\left.15, b=a^{3}\right\}\end{array}$ & $\begin{array}{l}1.69 \\
139\end{array}$ & $\begin{array}{l}293 \\
8 \times 91\end{array}$ & 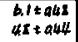 \\
\hline \multicolumn{2}{|c|}{$F D$} & 30 & & $\begin{array}{l}1>2 \\
170\end{array}$ & $\begin{array}{l}8.27 \\
7.26\end{array}$ & 20 & & $\begin{array}{l}1.14 \\
152\end{array}$ & $\begin{array}{l}671 \\
x .24\end{array}$ & $\begin{array}{l}38 \div 040 \\
47 \pm 040\end{array}$ \\
\hline \multirow{2}{*}{\multicolumn{2}{|c|}{$\frac{5}{5} x^{\frac{3}{2}}$}} & 30 & $a, \pm a 18$ & 0.99 & $\mid a=3$ & 20 & $4.9: 0.15$ & $a b b$ & 3.47 & $0.2 \pm 0.23$ \\
\hline & & 30 & $21.7=0.27$ & $14 \%$ & $6 \geq 7$ & 20 & & H $H z$ & 776 & $4 \div a 41$ \\
\hline \multirow{2}{*}{\multicolumn{2}{|c|}{ 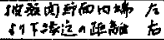 }} & 30 & 22.9 & 1.76 & 7.69 & 20 & & 100 & 538 & Q40 \\
\hline & & 30 & & $1.2 \mathrm{z}$ & & 20 & & 603 & 502 & \\
\hline \multirow{2}{*}{\multicolumn{2}{|c|}{ 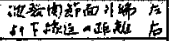 }} & 30 & & 138 & $80 z$ & 20 & & 1.24 & 3.51 & \\
\hline & & 30 & & 139 & 8.13 & 20 & & 1.12 & 259 & 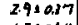 \\
\hline \multirow{2}{*}{\multicolumn{2}{|c|}{ 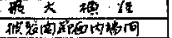 }} & 30 & 24.5 & 236 & 5.58 & 20 & 0.22 & 1.23 & a?1 & as 4 \\
\hline & & 30 & & 1,32 & 1045 & 20 & & $10 b$ & 10.71 & \\
\hline \multicolumn{2}{|r|}{ 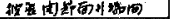 } & 30 & 20.92 & 126 & 203 & 20 & 16.920 .19 & ext & 503 & $40 \div 0,30$ \\
\hline \multicolumn{2}{|r|}{$x$} & 30 & & 446 & $\mid 0,0.5$ & 20 & & 3.72 & 5.60 & \\
\hline \multirow{3}{*}{ 筧 } & 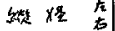 & $\begin{array}{l}30 \\
30\end{array}$ & & $\begin{array}{l}a 97 \\
a \neq b\end{array} \mid$ & $\left|\begin{array}{l}1426 \\
122 b\end{array}\right|$ & 20 & $a, b$ & $\begin{array}{l}a_{3} \\
0,58\end{array} \mid$ & $\left|\begin{array}{l}2.52 \\
1074 \\
1074\end{array}\right|$ & $\begin{array}{l}4 \times 0.24 \\
2 \pm 0.19\end{array}$ \\
\hline & 梏 & 30 & & 055 & 1528 & 20 & & 039 & 22.53 & $0 . / 3$ \\
\hline & & 30 & & & & 20 & & 0.59 & & \\
\hline \multirow{3}{*}{ 留零 } & 裉 & 30 & & 0,60 & 1304 & 20 & & 287 & 1933 & \\
\hline & & & & Q.4 & & 20 & & $a x b$ & & \\
\hline & 祰 任 & 30 & & $\begin{array}{l}a b ! \\
a \leq 8\end{array}$ & $\mid \begin{array}{l}7.56 \\
13.18\end{array}$ & 20 & & 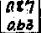 & $\mid \begin{array}{l}18.33 \\
17.50\end{array}$ & $\begin{array}{l}0.0 \pm 0.47 \\
0.8 \pm 0.1\end{array}$ \\
\hline
\end{tabular}

2）披裂関節面形態

·表9に示すように，両性共に腎臓形を呈するむのが過 半数を占めて最く多く，次いで棈円形が尿々現われ，一 側が腎榩形で他側が棈円形を呈するるのが少数認められ た。

表 9 披裂関舫面殁態

\begin{tabular}{|c|c|c|c|c|c|c|}
\hline 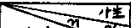 & & 合 & & 古 & & $5+\frac{9}{b}$ \\
\hline 形势 & 30 & $\%$ & 20 & $\%$ & 50 & $\%$ \\
\hline 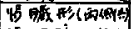 & 19 & $03.3+8.80$ & 12 & $60.0 * 10.95$ & 31 & 62.020 .26 \\
\hline 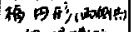 & $x$ & $2 b .7=8.08$ & 6 & $30.0 \times 10.25$ & 14 & $25,020,35$ \\
\hline 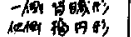 & 3 & $10,0 \pm 5,4 \pi$ & $z$ & $10.0=6,33$ & 5 & 10.01424 \\
\hline
\end{tabular}

3）甲状関節面

甲状関節面は明瞭なるの更び不明瞭なるのがあり，表 10 に示すように.全然欠如しているものは 15例 (30.0\% $\pm 6.48 \%$ ）で，見掛上は女性に批いで男性の約 2 倍を 算し，又右側の及欠如しているものは男女共 1 例も見ら れなかつた。

表 10 甲状関閏面欠如率

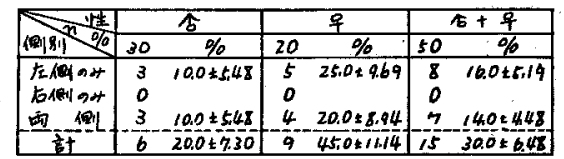

4）翰状軟胃板部の形状

i) 板 部 示 標

輸状軟䨋板部の形態を比較的簡単に表示するのに，表 11 に示すように Waldeyer の 2 種の示標を用いた。

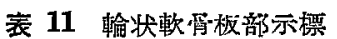

\begin{tabular}{|c|c|c|c|c|c|}
\hline \multirow{2}{*}{\multicolumn{2}{|c|}{ 標 $\frac{r l}{\%}$}} & \multicolumn{2}{|r|}{ 霖 } & \multicolumn{2}{|r|}{ 오 } \\
\hline & & 30 & $\%$ & 20 & $\%$ \\
\hline \multirow{3}{*}{ 右性墂 } & $61-70$ & 7 & $23.3 \pm 772$ & 0 & \\
\hline & $71-80$ & 17 & $56.7+9.04$ & 11 & $550 \pm 11,14$ \\
\hline & $81-90$ & $b$ & $200 \pm 203$ & 9 & $45,0 \pm 1114$ \\
\hline \multirow{4}{*}{ 高机標 } & $n / \sim 0$ & 1 & $3.3 \pm 3.26$ & $D$ & \\
\hline & $81 \sim 90$ & 11 & $36.7 \pm 8.80$ & 15 & $75,0 \pm 9.69$ \\
\hline & $9 / \sim 100$ & 17 & $567 \pm 9.04$ & 5 & $25.0 \times 9.69$ \\
\hline & $100 \mathrm{WL}$ & 1 & $3.3 \pm 326$ & 0 & \\
\hline
\end{tabular}

a. 広々示標：これは主に甲状関節突起の 発育の移度 によって左右されるものであり，女性は全般的に示標か 大红傾いている・即ち女性の方が甲状関節突起の発尙が 軽度である事を表わしている。

b. 高広示標：これは主に板部気営輪状軟骨の形態が 細長いか，又は横広いかを示するので，男性では示標 91〜100 が女性では示標 81 90 が夫ょ多く，男性は女 性上り輪状軟骨板部が比較的や」短く広い事を示してい、 る。

\section{ii）上下縁}

輪状軟穼板部上下西縁は平坦でなく起伏があり一定せ

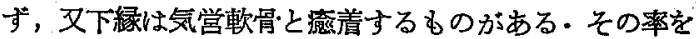
表示すれば、表12 のように上下車緑共宿四したものが多 く(上縁 $60.0 \% \pm 6.93 \%$ ，下縁 $54.0 \% \pm 7.05 \%$ )，た心゙女

表 12 輪状軟骨板上下綠

\begin{tabular}{|c|c|c|c|c|c|c|c|}
\hline \multirow{2}{*}{\multicolumn{2}{|c|}{ 极部向性 }} & \multicolumn{2}{|r|}{ 今 } & \multicolumn{2}{|r|}{ 车 } & \multicolumn{2}{|r|}{$\delta+\frac{8}{1}$} \\
\hline & & 30 & $\%$ & 20 & $\%$ & 50 & $\%$ \\
\hline 上 & 凹 狍 & 21 & $700 \pm 8,37$ & 4 & $45,0411,14$ & 30 & $600 \pm 6.93$ \\
\hline 噥 & $\begin{array}{ll}7 & 18 \\
\text { 凸 } & \text { P㚅 }\end{array}$ & $\begin{array}{l}q \\
0\end{array}$ & $30,0 \pm 8.27$ & 11 & $55.0 \pm 11.14$ & $\begin{array}{r}20 \\
0\end{array}$ & $40.0 \pm 493$ \\
\hline 需 & 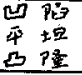 & $\begin{array}{r}17 \\
13 \\
0 \\
\end{array}$ & $\begin{array}{l}56.7 \pm 9.044 \\
43.3 \pm 9.04\end{array}$ & $\begin{array}{r}10 \\
9 \\
1\end{array}$ & $\begin{array}{r}50.0 \pm 11.18 \\
45.0 \pm 11.14 \\
5.0 \pm 488\end{array}$ & $\begin{array}{l}24 \\
22 \\
1\end{array}$ & $\begin{array}{r}540 \times 05 \\
44: 0+702 \\
2.0+1.98\end{array}$ \\
\hline
\end{tabular}


珄で上緑の 平坥なむのがや」多く $(55.0 \% \pm 11.14 \%)$, 下緑では隒凹したもの及び平坦なるのは活ら同率であ

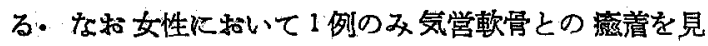
た.

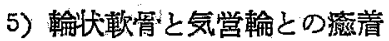

輸状軟骨下縁と気営輪との癒着は表 13 に示すように， 13 例 $(26.0 \% \pm 6.21 \%)$ において見られ，男性よりも見 排上は女性にや」多い，側別では男女共左側のみに認め られるものがや」多く，女性で両側共漓着したものが 1 例讃められた。

表 13 輸状軟骨と気管輸との當着側別

\begin{tabular}{|c|c|c|c|c|c|c|}
\hline & & 实 & & 星 & & $\hat{\beta}+q$ \\
\hline 6 & 30 & $\%$ & 20 & $\%$ & 50 & $\%$ \\
\hline & 5 & 1 & 4 & $20.0 \pm 894$ & 9 & $18.0+543$ \\
\hline b甽のサ & $\begin{array}{l}1 \\
0\end{array}$ & & & $\begin{array}{r}10.020 .71 \\
5.0 \pm 4.88\end{array}$ & $\begin{array}{l}3 \\
1\end{array}$ & $\begin{array}{l}200336 \\
20 \pm 1.98\end{array}$ \\
\hline $\mathrm{Ft}$ & 6 & $200 \times 130$ & 7 & $35,0=10.68$ & 13 & $20.0 \pm 0.21$ \\
\hline
\end{tabular}

表 14 翰状軟㱏と気管輸との答着部位

\begin{tabular}{|c|c|c|c|c|c|}
\hline 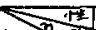 & & 零 & & 审 & 1 $1+$ + \\
\hline 初位 & 30 & $\%$ & 20 & $\%$ & $50 \%$ \\
\hline 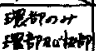 & $b$ & $20.0 \pm 4.30$ & & $\begin{array}{r}30.0 \pm 10.25 \\
5.0 \pm 488\end{array}$ & $\begin{array}{rr}12 & 24.0 \pm 6,43 \\
1 & 2.0 \pm 1,98\end{array}$ \\
\hline 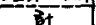 & 6 & $200 \times 730$ & 4 & $35,0 \pm 10,68$ & $26,0+k 21$ \\
\hline
\end{tabular}

更に痛着部位を見ると，表 14 に示すように，環部の 及と港着するすのが 13 例中 12 例で，女性で 1 例におい て環部及び板部と撚着していた・

3. 披裂軟骨"

1) 披裂軟骨計測值

披裂軟骨各部の大きさは表 15 に示す如くである・即 ち甲状, 輪状軟学計測值之同样男性が女性よりり優, 又 男女共左右計測值間には殆んど美異を想めない。

表 15 披裂软管㖣惻值（単位 $\mathrm{mm}$ )

\begin{tabular}{|c|c|c|c|c|c|c|c|c|c|c|}
\hline \multirow{2}{*}{\multicolumn{2}{|c|}{ 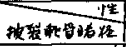 }} & \multicolumn{4}{|c|}{ 合 } & \multicolumn{4}{|c|}{9} & \multirow{2}{*}{ 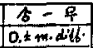 } \\
\hline & & $n$ & $M=m$ & $=$ & $v$ & $n$ & $M \pm m$ & $\sigma$ & $v$ & \\
\hline \multirow{2}{*}{\multicolumn{2}{|c|}{ 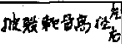 }} & 30 & $13,5 \div 041$ & 2.23 & 16.25 & 20 & $11.6+0.20$ & 0.92 & 7.43 & $1.9 \pm 0.46$ \\
\hline & & 30 & $140 \leqslant Q 4 Z$ & 2.27 & $\mid b, 2 t$ & 20 & $11.6 \div 0.22$ & 1.02 & 8.79 & $2.4 \pm 0.47$ \\
\hline \multirow{3}{*}{ 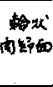 } & $x$ & 30 & $5.2 * 0,10$ & 260 & 11.54 & 20 & $4.4 \pm 0.11$ & 0.49 & 1,14 & al $\leqslant 0,15$ \\
\hline & $\frac{0}{n}$ & 30 & $\begin{array}{l}5.4 \pm 0.10 \\
49 \pm 0.09\end{array}$ & 0.518 & 9.94 & 20 & $4.100,04$ & 0,34 & 9,51 & $a .8=a / 3$ \\
\hline & & 30 & $49=0,12$ & 0.63 & 12.88 & 20 & $H 2 \leq 011$ & 0,48 & 10,03 & $a 7 \leq 0,16$ \\
\hline
\end{tabular}

\section{2) 輪状関節面形態}

縦径はや>压平された円形をなすものが大多数で，横 堆はすべて陥凹していた：

4. 艺の他の軟骨

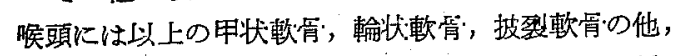

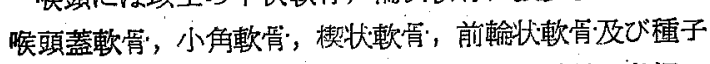

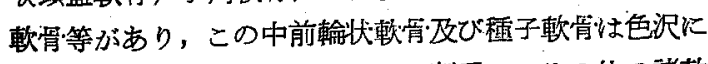
肉眼的観察のみでは不充分なため割要し，その他の諸軟 骨に就いては形状，存在に就いて注意して観察した・

\section{1) 唉䫒蓋軟肎·}

軟骨のみでの観察で法個体的に左程の相違はないが， これを粘膜が被うとその処に生ずる披裂喉頭蓋七がの状 態によって色々の形態が生ずる・この形態を図1のよら に 5 型に分類する之，蒜15 に示すようになる。

图 1 㘈頭㥺軟管形態

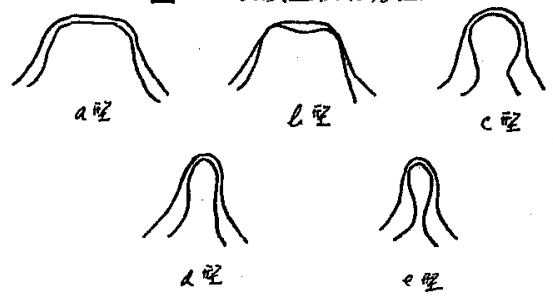

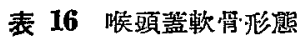

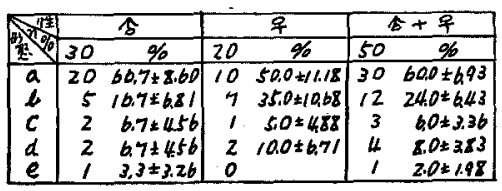

即ち a 型か過半数を占めて最も多く, $\mathrm{b}$ 型がこれに 次ぎ $(24 \%) ， a$ 及び $b$ 型で全例の大部分を占めて拉 り，その他の型は㪛ない，性別的には大差を諗めない。

2) 小角軟骨

披裂軟骨の尖端に結合組織により連絡されている小円 錐形の軟骬片で，筆者の調查例では全例に扎いて見られ (100\%)，大きさる殆えど大差を認めなかった。

3）楔状軟骨.

この軟骨怯 50 例中 5 例（男性 3 例，女性 2 例）に認 められたのみで，揳状結節を認めても実際はその中に軟 骨を認め始が非常に多く，5例中1例が左側のみに， 他の 4 例は両，側共に存在し残りの 45 例には 全然本軟 悬をと如していた。

比較:

1. 甲状軟写火ついて

1) 前縁の長さ

この長径は表 17 に示すよりに，本群男性は平均 17.6 $\mathrm{mm}$ で，支那人及び日本人 (尾閶) と殆えど大差を認め ないが，欧洲人（田口），エルザス人と比較すればや小 小であり，台湾蕃人より大である・女性性平均 $12.6 \mathrm{~mm}$ で，欧洲人（田口），エルザス人が大で，次いで台湾蕃 人，日本人 (尾関)の順で，九州日本人が最す小である・ 性別的には Velpean 支び Tillaux は一般に両性の 差を認めていないが，各人種共男性は女性より寒つてい 
る。

表 17 解・後維の長さ比较 (単位 $\mathrm{mm}$ )

\begin{tabular}{|c|c|c|c|c|c|c|c|c|c|c|}
\hline \multirow{2}{*}{ 人裡 } & \multirow{2}{*}{ 䇉吉者 } & & \multicolumn{4}{|c|}{ 含 } & \multicolumn{4}{|c|}{9} \\
\hline & & & $n$ & $M \pm m$ & $\max 1$ & min. & $n$ & $m \pm m$ & $\min$ & min. \\
\hline \multirow{10}{*}{ 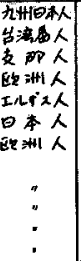 } & \multirow{10}{*}{ 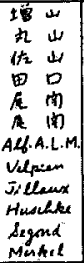 } & \multirow{10}{*}{$\begin{array}{l}\text { 蔽 } \\
\text { 情 } \\
9 \\
\text { 長 } \\
5\end{array}$} & \multirow{10}{*}{$\begin{array}{r}30 \\
6 \\
50 \\
29 \\
8 \\
60\end{array}$} & $176 \pm 972$ & 21.0 & 14,0 & 20 & $12.6 \pm 0.19$ & 140 & 11.0 \\
\hline & & & & 1445 & $1 a 80$ & 228 & 2 & 13.85 & 1410 & $\angle a b 0$ \\
\hline & & & & $12.3 \pm 0.36$ & 220 & 10.6 & & & & \\
\hline & & & & 19.0 & 220 & 120 & 29 & 145 & 12.0 & 12.0 \\
\hline & & & & 200 & 2,9 & /zo & 2 & 15.0 & & \\
\hline & & & & 17.0 & $|20.0|$ & $|, 3,0|$ & 43 & 13.5 & 20.0 & 12.0 \\
\hline & & & & line $z_{0}$ & $\boldsymbol{U}, \boldsymbol{H}$ & HAx & & & & \\
\hline & & & & $20-30$ & & & , & & & \\
\hline & & & & $70^{\circ}$ & & & & & & \\
\hline & & & & $\begin{array}{l}201 / 2 \\
60-904\end{array}$ & & & & $\begin{array}{l}60 \% \\
50 \% 4\end{array}$ & & \\
\hline 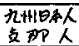 & $\begin{array}{l}\text { 绵 } \\
i \neq 2\end{array}$ & $\begin{array}{l}\text { 作 } \\
\text { 旅 }\end{array}$ & $\begin{array}{l}30 \\
50\end{array}$ & $\begin{array}{l}21.910 .33 \\
22.0\end{array}$ & $\begin{array}{l}29.0 \\
28.0\end{array}$ & $\begin{array}{l}150 \\
15.0\end{array}$ & 20 & $15,6 \pm 0.26$ & 19.0 & 120 \\
\hline
\end{tabular}

2) 後縁の長さ

この長圣は表 17 に示すように，支那人男子 $22.0 \mathrm{~mm}$ ， 九州日本人男子 $21.9 \mathrm{~mm}$ で, 而者共殆んど相一致して いる・

3）上角の長さ

これは表引18 に示すように，男性は平均 $14.4 \mathrm{~mm} て ゙ ，$ 支䛍人，日本人（尾関）と殆んと゚大差なく，ェルザス人 より小で，台湾蕃人よりやう大である。

表 18 上角の長さ比筬 (単位 $\mathrm{mm}$ )

\begin{tabular}{|c|c|c|c|c|c|c|c|c|c|}
\hline \multirow{2}{*}{ 人䄈 } & \multirow{2}{*}{ 韩告差 } & \multicolumn{4}{|c|}{5} & \multicolumn{4}{|c|}{ q } \\
\hline & & $m$ & $M \pm m$ & $\sin x$ & meins. & $n$ & $M \pm \dot{m}$ & $\operatorname{man}$ & min. \\
\hline 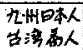 & $\begin{array}{ll}山 \\
\text { AL }\end{array}$ & $\begin{array}{r}30 \\
6\end{array}$ & $\begin{array}{l}14.4 \pm 0.43 \\
13,56\end{array}$ & $\begin{array}{l}22,0 \\
1 \pi .35\end{array}$ & $\begin{array}{l}8.0 \\
7.00\end{array}$ & $\begin{array}{r}20 \\
2\end{array}$ & $\begin{array}{l}12.1 \pm 0.31 \\
13,148\end{array}$ & $\begin{array}{l}16,0 \\
16,90\end{array}$ & $\begin{array}{l}9.0 \\
1155\end{array}$ \\
\hline 专加人 & 恠 山 & 50 & $14,7 \pm 0.28$ & 21.0 & 5.0 & & & & \\
\hline InT゙ス & 虬肉 & 8 & 17.0 & 200 & 14.0 & $z$ & 16.5 & & \\
\hline 日亩人 & 尾 & 60 & 15.0 & 23.0 & 8.0 & 43 & 125 & 170 & 10.0 \\
\hline
\end{tabular}

女性は平均 $12.1 \mathrm{~mm}$ でェルザス人の $16.5 \mathrm{~mm}$ に較ベ 小さく，日本人 (尾笋) とは殆んど一致し台湾蕃人より や小年あり，各人纁共すべて女性よりも男性が優つて れる。

上角は時な欠損する事・泫あると言われている汸，筆者 の調查例では 50 例中1例（女，左側）に認め，支那人男 子(佐山)では 50 例中 1 例もなく，又尾関は日本人男子 50 例中 1 例名諗めず，女子 43 例中 2 例に諗めたと報告 し，欧洲人ではこれに反し Schulze 惊 2.7\%，Waldeyer は男子 56 例中左側に 3 例，右側に 1 例，它右両側 各々1例を認めたと言う・即ち九州日本人においては支 那人及び日本人 (尾咸) と同様に上售の欠損は欧洲人に 比較して稀のようである・

\section{4) 上角の傾斜度}

甲状軟骨上角は甲状軟贡“後縁の延長線上に突出する事 は殆んどなく，多少前内方又は後内方に傾斜し，筆者は その知状面に拈ける傾斜度と上角と甲状軟屑板上縁との な寸角で計測した・
表 19 上角の倾斜店比軦（単位 ${ }^{\circ}$ ) $\cdots$

\begin{tabular}{|c|c|c|c|c|c|c|c|c|c|}
\hline \multirow{2}{*}{ 人㮒 } & \multirow{2}{*}{ 较考者 } & \multicolumn{4}{|c|}{ S } & \multicolumn{3}{|c|}{ an } & \multirow{2}{*}{$\frac{1}{\sin 2 \pi}$} \\
\hline & & $n$ & $M \pm m$ & max. & thins. & $n$ & $M \perp M$ & $m u$. & \\
\hline $\begin{array}{l}n+16 \times x \\
p=n k \alpha\end{array}$ & 增山 & 30 & $\begin{array}{l}94761.91 \\
1077\end{array}$ & $\begin{array}{l}130 \\
126\end{array}$ & $\begin{array}{l}60 \\
i 9\end{array}$ & $\begin{array}{r}20 \\
2\end{array}$ & $\begin{array}{l}49.0 \pm 2.00 \\
1047\end{array}$ & $\begin{array}{l}130 \\
110\end{array}$ & $\begin{array}{c}90 \\
100\end{array}$ \\
\hline 支邵人 & 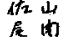 & 50 & $99.1 \div 1.15$ & 130 & $\begin{array}{l}60 \\
70\end{array}$ & 2 & 75 & 100 & 70 \\
\hline$\theta \times x$ & 公尚 & 60 & 40 & 130 & 10 & 43 & 90 & 130 & .90 \\
\hline
\end{tabular}

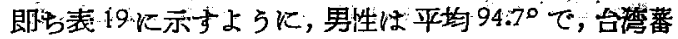
人，支制人より小で，エルザス人及び日本人（尾関）より や」大である・姓は平均 $99.0^{\circ}$ で，台㦄蕃人ょり小で

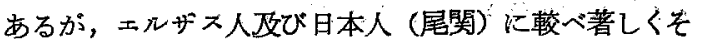
の角度は大である・

更に性別を比較すると，日本人（尾関） では男女全く 一致し，ェルザス人，合弯蕃人では男性が勝れているの に反し，九州日本人に执いて女性吕男性より㷴つている のは注目に值する・

更に文との左右を比較すると，表 20 に示すように不 均等なものが $62.0 \%$ で，男女共過半数を占め，佐山の 支䛍人男子 $52.0 \%$ ，尾閣の日本人 $56.9 \%$ (男 $53.3 \%$ ，女 $59.3 \%$ ) の埸合とほざ一致する.

表 20 上角の傾斜度左右比鞳 (単位 ${ }^{\circ}$ )

\begin{tabular}{|c|c|c|c|c|c|c|c|c|c|}
\hline \multirow[b]{2}{*}{ 人被 } & \multirow{2}{*}{ 积告半 } & \multicolumn{3}{|r|}{ 合 } & \multicolumn{3}{|r|}{$\frac{9}{9}$} & \multicolumn{2}{|r|}{ 古+ 昌 } \\
\hline & & $: n$ & E1 & $\%$ & $n$ & is & 96 & $n$ & $\%$ \\
\hline $\begin{array}{l}n+1+4 x \\
4: 0 \alpha\end{array}$ & 橧山 & $\begin{array}{r}30 \\
6\end{array}$ & & $\begin{array}{l}664 \pm 860 \\
1000\end{array}$ & 20 & & $\begin{array}{l}55,0 \pm 11.14 \\
100,0\end{array}$ & $\begin{array}{r}50 \\
7\end{array}$ & $\begin{array}{cc}316204696 \\
71000\end{array}$ \\
\hline 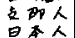 & s/2w & $\begin{array}{l}50 \\
38\end{array}$ & 26 & $\begin{array}{l}t z 0 \pm 700 \\
5 \pm 0 \pm 0.04\end{array}$ & 27 & 16 & $59.3 \div 846$ & 65 & $97569=k 24$ \\
\hline
\end{tabular}

\section{5）下角の長さ}

この長さは表 21 に示すように，男性は平均 $6.1 \mathrm{~mm}$ で，ェルシ人より著しく小で，支那人，台湾蕃人とは 殆んど大差を認めず，日本人 (尾朚)よりや」小である。 女性悟平均 $5.1 \mathrm{~mm}$ でェルザス人，台弯蕃人，日本人 (尾閏)より小である・性別は台湾蕃人では女性が男性 より優り，他往全人種共男性が勝れている。

表 21下筩の長さ比較 (单位 $\mathrm{mm}$ )

\begin{tabular}{|c|c|c|c|c|c|c|c|c|c|}
\hline \multirow{2}{*}{ 人社 } & \multirow{2}{*}{ 教告旨 } & \multicolumn{4}{|c|}{5} & \multicolumn{4}{|c|}{$q$} \\
\hline & & $n$ & $M \pm m$ & $\max x$ & $\mathrm{mins}$. & $n$ & $M \pm=$ & max. & man. \\
\hline 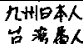 & $\begin{array}{l}\text { 增山 } \\
\text { 凡 } 4\end{array}$ & $\begin{array}{r}30 \\
4\end{array}$ & $\begin{array}{l}b .1 \pm 0.13 \\
6.54\end{array}$ & $\begin{array}{l}4.0 \\
775\end{array}$ & $\begin{array}{l}5.0 \\
5.20\end{array}$ & $\begin{array}{r}20 \\
2\end{array}$ & $\begin{array}{l}5,1 \pm 6,13 \\
209\end{array}$ & 7.0 & 30 \\
\hline 专那人 & 传山 & 50 & $b .3 \pm 0.11$ & 10.0 & 40 & & & & \\
\hline IUH 2 人 & 右闻 & 8 & 10.0 & 120 & 8.0 & 2 & 75 & 2.0 & 7.0 \\
\hline 旦本人 & 尾肉 & bo & 8.5 & 1200 & bo & 43 & ho & 20 & 500 \\
\hline
\end{tabular}

6) 軟覓板の幅

i）上緑の幅：表 22 に示すよ5に，男珄では九州日 本人 $41.5 \mathrm{~mm}$ ，エルザス人 $42.0 \mathrm{~mm}$, 支那人. $41.4 \mathrm{~mm}$

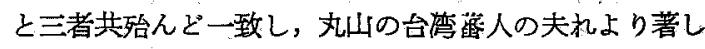
く大で，尾関の日本人の夫れより稍〉大である・女泩は 平均 $29.4 \mathrm{~mm}$ でェルザス人，日本人.(尾関) と㱠んど 


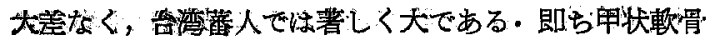

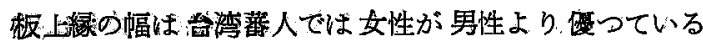
为、他の人種ではすべて男性が女性より優つている。

表 22 軟霄板市比較 (単位 $\mathrm{mm}$ )

\begin{tabular}{|c|c|c|c|c|c|c|c|c|c|c|}
\hline \multirow{2}{*}{ 人侬 } & \multirow{2}{*}{ 隺告者 } & & \multicolumn{4}{|c|}{ t } & \\
\hline & & & & $1 \pm m$ & $m x x$ & mik. & $M$ & $M=m$ & $\max$. & \\
\hline & 㙁山 & 步 & 30 & $\begin{array}{l}41,5 \pm 0,38 \\
32.5 x\end{array}$ & $\begin{array}{l}42.0 \\
35.65 \\
0.0\end{array}$ & $\begin{array}{c}350 \\
30,05 \\
350\end{array}$ & $\begin{array}{r}20 \\
2\end{array}$ & $\begin{array}{l}224 * 0.31 \\
3411\end{array}$ & $\begin{array}{l}320 \\
3925\end{array}$ & \\
\hline & & & 50 & 4.4 & 51.0 & 35.0 & & & & \\
\hline & $A$ 直 & & $\begin{array}{l}8 \\
6 D\end{array}$ & & $\begin{array}{l}45,0 \\
470\end{array}$ & $\begin{array}{l}38.0 \\
250\end{array}$ & 2 & $\begin{array}{l}31.0 \\
29.0\end{array}$ & $\begin{array}{l}32.0 \\
32.0\end{array}$ & d \\
\hline & th & 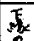 & 30 & $\begin{array}{l}244 \pm 031 \\
2 \pi 71\end{array}$ & $\begin{array}{l}340 \\
3060\end{array}$ & $\begin{array}{l}270 \\
27,40\end{array}$ & 20 & $\begin{array}{l}23.4 \pm 0.21 \\
28.11\end{array}$ & 24,0 & \\
\hline & & & & & 31.0 & & & & & \\
\hline
\end{tabular}

ii）下緑の幅：表 22 に示すよ 5.に，男性は平均 29.4 mm で支那人ょりや\小で，台湾菜人よりや」大であ り，女性では台湾蕃人より小である・男女間では台湾蕃 人の場合女性の方が優つているが，これは上縁の幅の場 合も同样に例数が少ないので確帚する事はできない。

\section{7) 軟管板の高さ}

i）前部の高さ：表 23 に示すよ5に，男性は 平均 $25.6 \mathrm{~mm}$ で，エルザス人，欧洲人（田口）が 最も大で，賁那人，日本人(尾関)，欧洲人(Luschka) 亦り小で，台湾蕃人より大である・女性は平均 19.3 $\mathrm{mm}$ で，台湾蕃人，エルザス人，欧洲人（田口）上 り小で，日本人（尾関）よりや今小である.

表 23 軟霄板商比䡴 (単位 $\mathrm{mm}$ )

\begin{tabular}{|c|c|c|c|c|c|c|c|c|c|c|}
\hline \multirow{2}{*}{ 人樰 } & \multirow{2}{*}{ 刺告者 } & & \multicolumn{4}{|c|}{ s } & \multicolumn{4}{|c|}{ 우 } \\
\hline & & & $n$ & $M \pm m$ & mex. & mis. & $n$ & $M \pm m$ & mes. & $\min$, \\
\hline 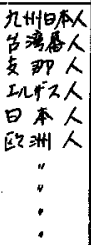 & 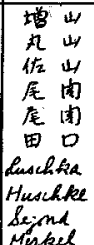 & $\begin{array}{l}\text { 前 } \\
\text { 部 } \\
\text { 是 } \\
\text { 量 } \\
\text { ? }\end{array}$ & $\begin{array}{r}30 \\
6 \\
50 \\
8 \\
60 \\
29\end{array}$ & $\begin{array}{l}25.6 \pm 0.25 \\
23.29 \\
28.1 \pm 0.27 \\
32.0 \\
27.0 \\
31.0 \\
27.0 \\
149 \\
134 \\
129 \sim 248\end{array}$ & $\begin{array}{l}30,0 \\
26,75 \\
38,0\end{array}$ & $\begin{array}{l}23,0 \\
21,20 \\
22.0\end{array}$ & $\begin{array}{r}20 \\
2 \\
2 \\
43 \\
29\end{array}$ & $\begin{array}{l}19.3 \pm 0.17 \\
24.69 \\
23.0 \\
20.5 \\
22.5 \\
9^{4} \\
10^{4} \\
81 / 2\end{array}$ & $\begin{array}{l}21.0 \\
25.20\end{array}$ & $\begin{array}{l}140 \\
20,95\end{array}$ \\
\hline 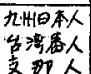 & 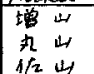 & $\begin{array}{l}x=2 \\
\frac{y}{2} p\end{array}$ & $\begin{array}{r}30 \\
4 \\
50\end{array}$ & $\begin{array}{l}230 \pm 0.27 \\
1454 \\
24.2 \pm 0.25\end{array}$ & $\begin{array}{l}27.0 \\
31.0\end{array}$ & $\begin{array}{l}180 \\
18.0\end{array}$ & $\begin{array}{r}20 \\
2\end{array}$ & $\begin{array}{l}10,8 \pm 0,26 \\
10.45\end{array}$ & 19.0 & 140 \\
\hline
\end{tabular}

ii) 後部の高さ：表 23 に示すように，男性は平均 $23.0 \mathrm{~mm}$ で，支那人と此較して殆んど大差なく，台湾蕃 人より著しく大であり，女性は平均 $16.8 \mathrm{~mm} て ゙ ，$ 台湾 蕃人と殆んど一致する・

性別では前部及び後部の高さ共に，台湾蕃人を堬いて 㤹べて男性が女性より優つている。

8）甲状軟目·前角度

この角度は表 24 に示すように，男性は平均 $72.7^{\circ}$ で， 欧洲人 (Merkel, Luschka, Chievitz)より小で，欧洲 人(Waldhyer)，支那人，エれザス人と殆んで同大であ
るが，日本人 (尾関) 及び台湾蕃人より大である.

女性は平均 $88.8^{\circ}$ で，欧洲人，九州日本人，エルザス 人，日本人（尾関）の順で，台湾蕃人では著しく他人種 に較べ劣つているが，こ机例数が少なくて明確でない とは言え注目に值するものである。

文性別に和いては台湾蕃人を除いて全種族に抌いて女 性が男性より儊つているのも篦者の調查例と全く一致す る。

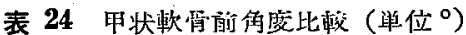

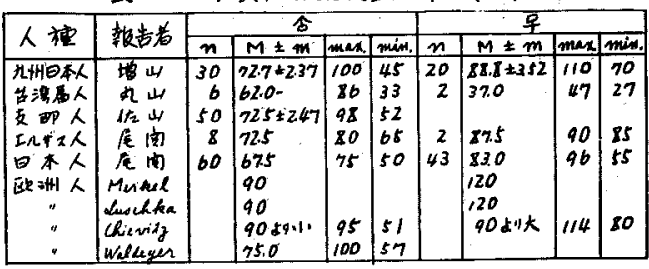

表 25 上甲状切痕の深さ及び角度比轻（単位 $\mathrm{mm},{ }^{\circ}$ )

\begin{tabular}{|c|c|c|c|c|c|c|c|c|c|c|}
\hline \multirow{2}{*}{ 人㮔 } & \multirow{2}{*}{ 㲦告者 } & & \multicolumn{4}{|c|}{ 占 } & \multicolumn{4}{|c|}{$F$} \\
\hline & & & $n$ & $M \pm m$ & Imax & priot. & $n$ & $M \neq m$ & mix. & $\min x$ \\
\hline $\begin{array}{l}\text { 九州本人 } \\
\text { 吕湾唇人 }\end{array}$ & $\begin{array}{c}\omega \\
\text { 凡 } 山\end{array}$ & & $\begin{array}{r}30 \\
7\end{array}$ & $\begin{array}{l}9.4 \pm 0.44 \\
11.54\end{array}$ & $\begin{array}{l}18.0 \\
14.45\end{array}$ & $\begin{array}{l}6.0 \\
2.00\end{array}$ & $\begin{array}{r}20 \\
2\end{array}$ & $\begin{array}{l}3,1120,28 \\
1338\end{array}$ & $\begin{array}{l}13,0 \\
15,60\end{array}$ & $\begin{array}{l}5.0 \\
11.15\end{array}$ \\
\hline 专 $A P$ 人 & 传山 & 棌 & 50 & $11.7+0,58$ & 30 & 7.0 & 7 & & & \\
\hline $\begin{array}{l}\text { ILIZ人人 } \\
\text { 日本人 }\end{array}$ & 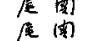 & & $\begin{array}{r}8 \\
60\end{array}$ & $\begin{array}{l}2.0 \\
10.0\end{array}$ & $\begin{array}{l}15.0 \\
13,0\end{array}$ & $\begin{array}{l}10 \\
6.0\end{array}$ & 43 & $\begin{array}{l}8.0 \\
7.0\end{array}$ & 10,0 & 5.0 \\
\hline $\begin{array}{c}\text { 欧 } 3+11 \\
\vdots\end{array}$ & $\begin{array}{l}\text { Do } 0 \\
\text { Huschles } \\
\text { Beyond }\end{array}$ & ? & 29 & $\begin{array}{r}12.0 \\
55 \\
64\end{array}$ & & & 29 & $\begin{array}{l}8.0 \\
31 / 24 \\
45\end{array}$ & & \\
\hline 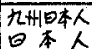 & 增宸和 & 雾 & $\begin{array}{l}30 \\
57\end{array}$ & $\begin{array}{l}47.7 \pm 3.18 \\
53.99,36\end{array}$ & $\begin{array}{l}80 \\
73\end{array}$ & $\begin{array}{l}20 \\
34\end{array}$ & $\begin{array}{l}20 \\
33\end{array}$ & $\begin{array}{l}58.5 \times 3.45 \\
55.3 \pm 1.78\end{array}$ & $\begin{array}{l}80 \\
80\end{array}$ & $\begin{array}{l}30 \\
49\end{array}$ \\
\hline
\end{tabular}

9）上甲状切痕の梁さ

この梁さは表 25 に示すよらに，男性は平均 9.4 $\mathrm{mm}$ でエルザス人，欧洲人（田口），支那人，台湾 蕃人，日本人（尾関）の順で，いずれも九州日本人 より大であるが，女性は平均 $7.1 \mathrm{~mm}$ で台湾蕃人， ェルザン人，欧洲人（田口）より著しく小で，日本 人（尾䦎）とは相一致している・性別では台湾蕃人 を除き他忧べて男性が女性より優つているのむ九 州日本人と一致する。

10) 上甲状切痕の角

本角度は表 25 に示すように，男性性平均 $47.7^{\circ}$ で，日 本人（松島）より小であり，女性は平均 $58.5^{\circ}$ で，松島

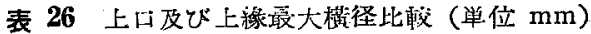

\begin{tabular}{|c|c|c|c|c|c|c|c|c|c|}
\hline \multirow{2}{*}{ 人福 } & \multirow{2}{*}{ 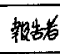 } & \multirow{2}{*}{ 性 } & \multirow{2}{*}{$n$} & \multicolumn{3}{|c|}{ 上D㧼媞 } & \multicolumn{3}{|c|}{ 上能最大柏㹥 } \\
\hline & & & & $M \pm m$ & $\max$ & miss. & $M \pm m$ & $\lim a x$. & $\operatorname{mix.}$ \\
\hline 九H标人 & 增山 & 古 & $\begin{array}{l}30 \\
20\end{array}$ & & $\begin{array}{l}48.0 \\
37.0\end{array}$ & $\begin{array}{l}35.0 \\
30,0\end{array}$ & $\begin{array}{l}43,5 \pm 0.75 \\
2 b, 3 \pm 0,43\end{array}$ & $\begin{array}{l}530 \\
400\end{array}$ & $\begin{array}{l}370 \\
340\end{array}$ \\
\hline 台溜忽人 & れ山 & 古 & $\begin{array}{l}b \\
z\end{array}$ & $\begin{array}{l}35,35 \\
32.48\end{array}$ & $\begin{array}{l}47.15 \\
37.90\end{array}$ & $\begin{array}{l}33,00 \\
28,05\end{array}$ & $\begin{array}{l}40.63 \\
28.03\end{array}$ & $\begin{array}{l}4955 \\
440\end{array}$ & $\begin{array}{l}3290 \\
32,00\end{array}$ \\
\hline 及 $\mathrm{p}$ 人 & 传山 & 5 & 50 & $39.8 \pm 0.64$ & 48.0 & 30.0 & $41.5 \pm 0.70$ & 52.0 & 30,0 \\
\hline エしヴス人 & 尾央 & 5 & 8 & & & & $\begin{array}{l}45.0 \\
38.0\end{array}$ & 480 & 320 \\
\hline 由A & 南 & s & 60 & & & & 40,0 & 150.0 & 35.0 \\
\hline
\end{tabular}


の埸合と殆んぞ一致している・又性別では両者共女珄が

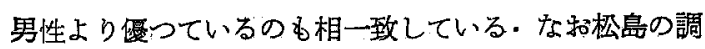
查例は病理解剖屍体より得た数值であるが，他に比較の 対照がなかつたので参考とした。

11) 甲状軟骨横径

i）上口横径：表 26 に示すように，男性は平均 40.6 $\mathrm{mm}$ で，台湾蕃人ょり大で支那人と殆んど差異を認め ず，女性は平均 $33.6 \mathrm{~mm}$ で，台湾蕃人より小である・

ii）上縁最大横径：表 26 に示寸ように，男性は平均 $43.5 \mathrm{~mm}$ で，ェルザス人より小であるが，支那人，台湾 蕃人，日本人（尾関）よりや」大であり，女性は平均 $26.3 \mathrm{~mm}$ で，ェルザス人より著しく小で，台湾蕃人より やら小である（尾関の場合は上甲状結節の高さに和ける 両側板後縁間の距離を参考とした)・

iii）上甲状結節間距離：表 27 に示すように，男性は 平均 $45.5 \mathrm{~mm}$ で, 支蕃人と類似し台湾蕃人よりや〉大 であり，女性は平均 $37.5 \mathrm{~mm}$ で，台湾蕃人より小であ る.

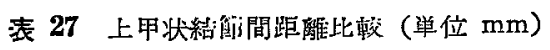

\begin{tabular}{|c|c|c|c|c|c|c|c|c|c|}
\hline \multirow{2}{*}{ 人理 } & \multirow{2}{*}{ 和告居 } & \multicolumn{4}{|c|}{$\boldsymbol{s}$} & \multicolumn{4}{|c|}{ 오 } \\
\hline & & $n$ & $M \pm m$ & max. & mls. & $n$ & $M \pm m$ & max. & andor. \\
\hline 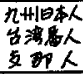 & $\begin{array}{l}\text { 壦山 } \\
\text { 凡心 } \\
\text { 传山 }\end{array}$ & $\begin{array}{r}30 \\
6 \\
50\end{array}$ & $\begin{array}{l}45.5 \pm 0.74 \\
42.41 \\
44.4 \pm 0.58\end{array}$ & $\begin{array}{l}520 \\
50.65 \\
54.0\end{array}$ & $\begin{array}{l}34.0 \\
37.15 \\
36.0\end{array}$ & 20 & $\begin{array}{l}37.5 \pm 0.44 \\
40.50\end{array}$ & $\begin{array}{l}420 \\
4460\end{array}$ & 0.35 .0 \\
\hline
\end{tabular}

iv）下口横径：表 28 に示すように，男性は平均 30.7 $\mathrm{mm}$ で，台湾蕃人より大で支那人より小であり，女性 は平均 $24.2 \mathrm{~mm}$ で，台湾蕃人より小である・

表 28 下ロ及び下緣最大橫径比䌽 (単位 $\mathrm{mm}$ )

\begin{tabular}{|c|c|c|c|c|c|c|c|c|c|}
\hline \multirow{2}{*}{ 人理 } & \multirow{2}{*}{ 叔告有 } & \multirow{2}{*}{ 性 } & \multirow[b]{2}{*}{$n$} & \multicolumn{3}{|c|}{ F } & \multicolumn{3}{|c|}{ f甘k } \\
\hline & & & & $M \pm m$ & gxas. & $\min$. & $M \pm m$ & mex. & . \\
\hline 几力川时本人 & 增山 & $\begin{array}{l}\hat{\sigma} \\
q\end{array}$ & $\begin{array}{l}30 \\
20\end{array}$ & $\begin{array}{l}30.7 \pm 0.35 \\
242 \pm 0.31\end{array}$ & $\begin{array}{l}34.0 \\
270\end{array}$ & $\begin{array}{l}220 \\
220\end{array}$ & $\begin{array}{l}33.5 \pm 0.37 \\
27.1 \pm 0.21\end{array}$ & 37.0 & $\begin{array}{l}30.0 \\
25.0\end{array}$ \\
\hline 台湾和人 & n山 & $\begin{array}{l}5 \\
8\end{array}$ & $\begin{array}{l}4 \\
z\end{array}$ & & $\begin{array}{l}3105 \\
3090\end{array}$ & $\begin{array}{l}2440 \\
22.40\end{array}$ & $\begin{array}{l}30,01 \\
22,65\end{array}$ & $\begin{array}{l}3410 \\
30.50\end{array}$ & $\begin{array}{l}2460 \\
2420\end{array}$ \\
\hline 支人 & $1 / 24$ & $\frac{1}{b}$ & 50 & $31.6 \pm 0.35$ & 370 & $2 \times 0$ & 36.030 .89 & 62.0 & 30.0 \\
\hline エルザス人 & fE直 & 5 & $\begin{array}{l}x \\
z\end{array}$ & & & & $\begin{array}{l}39.0 \\
31.0\end{array}$ & $\begin{array}{l}440 \\
320\end{array}$ & 340 \\
\hline 日大 & 尾同 & 令 & $\begin{array}{l}60 \\
43\end{array}$ & & & & $\begin{array}{l}35.0 \\
28.0\end{array}$ & $\begin{array}{l}4000 \\
40.0\end{array}$ & $\begin{array}{l}2500 \\
2400\end{array}$ \\
\hline
\end{tabular}

v）下縁最大横径：表 28 に示すように，男性は平均 $33.5 \mathrm{~mm}$ で，エルザス人が最も大で，支制人，日本人 (尾関) のいずれよりも小で台湾蕃人より大であり,㚣 性は平均 $27.1 \mathrm{~mm}$ で，エルザス人が最も優つている外， 九州日本人，台湾蕃人，日本人（尾開）といずれも類似 している.

特別では甲状軟㱏:横径の全諸径に执いて全種族共九州 日本人同様男性は女性より伐つている、

12）甲状軟皆前後径 i) 最大前後径：表 29 に示寸ように,黒性は平均 37.2 mm で，合湾蕃人，支那人の夫れより太で，如性情 均 $27.7 \mathrm{~mm}$ で, 台湾蕃人の $33.98 \mathrm{~mm}$ より年つている。

表 29 前後径比較 (単位 $\mathrm{mm}$ )

\begin{tabular}{|c|c|c|c|c|c|c|c|c|c|}
\hline \multirow{2}{*}{ 人社虽 } & \multirow{2}{*}{ 钱告者 } & \multirow[b]{2}{*}{ 性 } & \multirow[b]{2}{*}{$\boldsymbol{n}$} & \multicolumn{3}{|c|}{ 是大莎猪理 } & \multicolumn{3}{|c|}{ 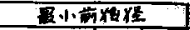 } \\
\hline & & & & $M \pm m$ & mex & min. & $M \pm m$ & mex. & $m$ m. \\
\hline & 增山 & $\begin{array}{l}\text { 点 } \\
\text { 索 }\end{array}$ & & & $\begin{array}{l}45.0 \\
33.0\end{array}$ & & & $\begin{array}{l}31.0 \\
31.0\end{array}$ & \\
\hline & & 18 & & & $\begin{array}{l}3540 \\
3250\end{array}$ & $\begin{array}{l}2900 \\
30.45\end{array}$ & & & 1920 \\
\hline 62 & $F$ & 客 & & $35 x+0.51$ & 45,0 & 26,0 & $27.3 \pm 0.54$ & 36,0 & mo \\
\hline
\end{tabular}

ii）最小前後径：表 29 に示すように，男性は平均 $26.4 \mathrm{~mm}$ で，支那人よりや」小であるが台湾蕃人より大 であり, 女性は平均 $20.1 \mathrm{~mm}$ で, 台湾蕃人の $22.95 \mathrm{~mm}$ より㸓つている。

性別では台湾蕃人は九州日本人とは反対に最大・最小 前後径に和いて女性がや小優つているが; これは調查例 数が少ないため明言する事ができない。

13) 㜊頭全高

i）側部：表 30 に示すよらに，男性は平均 $43.1 \mathrm{~mm}$ で欧洲人（田口），ェルザス人より小で，支删人：日本 人（松島，尾関）とは大した差異を認めず，女性は平均 $33.5 \mathrm{~mm}$ で欧洲人（田口）ょり小で，日本人(烃島)， ルザス人，日本人（尾関）とは殆んど類似している・性 別ではいずれも男性が女性より倀り，筆者の調查例と全 く一致する.

表 30 喉頭全高比較 (単位 $\mathrm{mm}$ )

\begin{tabular}{|c|c|c|c|c|c|c|c|c|c|c|}
\hline \multirow{2}{*}{ 人福 } & \multirow{2}{*}{ 壀告苔 } & & \multicolumn{4}{|c|}{ 今 } & \multicolumn{4}{|c|}{ 우 } \\
\hline & & & $n$ & $M \pm m$ & $\max$ & $\min$. & $n$ & $M \pm m$ & max. & $\min$. \\
\hline nt+⿴囗十 & 堵山 & & 30 & $43.1 \pm 0.32$ & 49.0 & 35.0 & 20 & $33.5 \times 028$ & 37.0 & 30.0 \\
\hline$\theta$ 本 & 枟息 & & 57 & $41.0 \pm 037$ & 47.0 & 36,0 & 35 & $35,0 \pm 0,52$ & 41.0 & 29.0 \\
\hline 支剭人 & 位山 & $\mid Q_{i t}$ & 50 & $42 \cdot 3 \pm 0,33$ & 55,0 & 34.0 & 3 & & & \\
\hline エルビス大 & 层 定 & & 12 & 45.0 & & & & 35,0 & & \\
\hline 日本人 & 尾 同 & & 60 & 41.0 & 48.0 & 30.0 & 45 & 33.0 & & \\
\hline 政㖄人 & 00 & 吾p & 35 & 48.0 & & & 33 & 32.0 & & \\
\hline . & $\begin{array}{l}\text { Row blat } \\
\text { Krance }\end{array}$ & & & $\begin{array}{l}48.0 \\
40,0\end{array}$ & & & & $\begin{array}{l}38,0 \\
30,0\end{array}$ & & \\
\hline 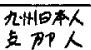 & $\begin{array}{l}\text { 增山 } \\
\text { 传山 }\end{array}$ & 賞 & $\begin{array}{l}30 \\
50\end{array}$ & $\begin{array}{l}325 \neq 0.37 \\
312 \neq 0.54\end{array}$ & $\begin{array}{l}38,0 \\
38,0\end{array}$ & $\begin{array}{l}2 b, 0 \\
12.0\end{array}$ & 20 & $26,5 \pm 0,38$ & 29,0 & 22.0 \\
\hline
\end{tabular}

ii）中央部：表 30 に示すよ 5 ，男性は平均 32.5 mm で支那人より僅かに優るが，殆んど類似している。

14) 甲状軟腎深広示標

これは表31に示すように，九州日本人男子は65 105 (严均 87.1) で，支都人男子の 64 127 (平均 85.9)

表 31 深広示標比較

\begin{tabular}{|c|c|c|c|c|c|c|c|c|}
\hline 人福 & 银告着 & 性 & $m$ & $M \pm m$ & $\sigma$ & $v$ & $\max$. & min. \\
\hline 九州日本人 & 增山 & $\begin{array}{l}5 \\
+ \\
+\end{array}$ & $\begin{array}{l}30 \\
20 \\
\end{array}$ & $\begin{array}{l}88.1 \pm 1.86 \\
81.6 \pm 1.00\end{array}$ & $\begin{array}{l}10,20 \\
4.51\end{array}$ & $\begin{array}{l}11.71 \\
t 553\end{array}$ & $\begin{array}{c}105 \\
88\end{array}$ & $\begin{array}{l}69 \\
65\end{array}$ \\
\hline 支那人 & $A / 2 \omega$ & 官 & 50 & $85.9 \pm 1.23$ & 8.70 & 10.13 & 127 & 64 \\
\hline E2 洲人 & waldeyen & 5 & 43 & & & & 100. & 53 \\
\hline
\end{tabular}


と殆んど近似しているが，欧洲人男子では 53〜100 と九 州日本人, 支那人に較心゙て小さい。

この示標は前述した通り，甲状軟帽前角度の大小に関

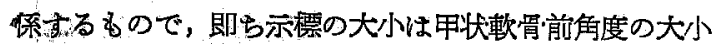

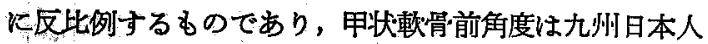
恔郍人と殆んど同大であるが，欧洲人では二者に比し 角度が大であるのは当然である。

15) 甲状軟婴子孔

本孔の存在は人類解部学上與味があるので特に注意し て研索した・而して出現頻度を文献より見ると，Henle は zuweilen, Rauber-Kopsch では manchmal に見る と言い, Sieglbaur 及び Gegenbaur は nicht selten, 'Spalteholz は一孔の存在が häufig であると言い, Schreier はレ線学的観察により1/3に認ゆられると記 載し，又 Merkel は一側に同時に2 ケの甲状軟学孔の 存在した例を報告している.Waldeyer も又甲状軟骨左 板に大小 2 ケの存在を認ゆている.

表 32 甲状軟骨孔比龫

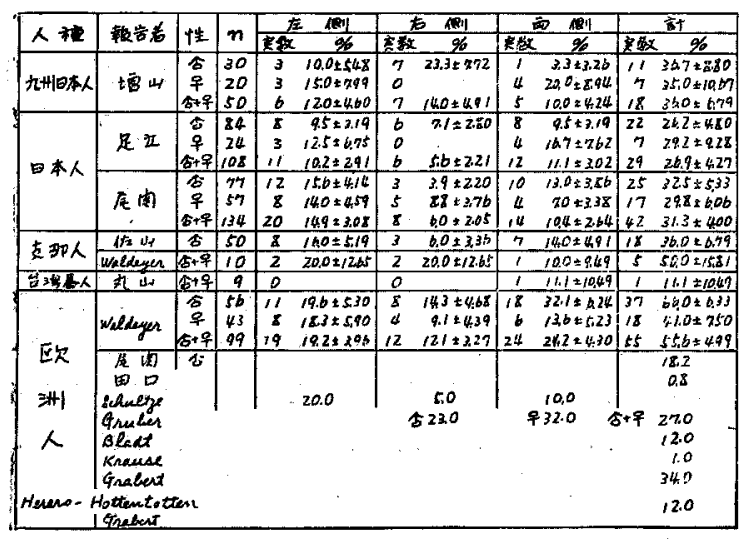

なお表 32 により各人種における成績を比較すると， 四本人では足立の $26.9 \%$ ，尾閔の $31.3 \%$ ，筆者の $36.0 \%$ 之九州日本人が前二者に比し多い. 又他人種との比較で は，欧班人においては伸ょ一定せす，Waldeyer の 55.6 \%に比し，又支那人（Waldeyer）の50.0\%に較べ，日 本人ではや〉少数である.

性別；性別により各人種間と比較すると，男性では 九州日本人，日本人(足立，尾関)，支那人間には殆んど 大差を認ゆず，欧洲人 (Waldeyer) は66.0\%と最も出 現卒が多い，女性では九州日本人が日本人(足立，尾関) むりや上優つているが，欧洲人（Waldeyer）上りはゃ や务っている・な挌田口，Krauseの成績を除外すれば，
丸山の台湾蕃人は最低の出現卒を示しているが，これは 調査例数が少ないたゆ他人種との異同を論ずる事はでさ ない.

側別；全人種に和いて片側に出現するすのは両側に 出現するるのより其の卒が多く，右側のみ，左側のみ， 両側に出現寸るものとに分つて比較すれは，日支人に紋 いて著しい差異を恐ゆないか，欧洲人（Waldeyer）に おいては両側に存在するものが著しく多い事は注目に値 する・

出現部位；表33に示寸ように，上甲状結節下部に出 現するものは九州日本人，支那人と殆んど一致し，日本 人（尾関）よりやつ勝れているが，これを更に前下部， 直下部に 分けた場合は九州日本人と 支那人では 全く逆 で，前者では前下部に多く諗ゆられたのに反し，後者で は直下部に多く存在している・文との他前方，後方では 日本人 (尾関) に特いてや〉多く認められているが，九 州日本人では前方に 2 例認められ，後方には1例む存在 せず，支那人では前方，後方に夫た 2 例宛認められたの

みで，九州日本人，支那人間では甲状軟盈孔出現部 位は殆んど頻似している。

変 33 甲状軟骨孔出现部位比輍（上甲状 結倠を䧲集として)

\begin{tabular}{|c|c|c|c|c|c|c|c|}
\hline \multirow{3}{*}{\multicolumn{2}{|c|}{$\underbrace{}_{\text {部仿 }}$}} & \multirow{2}{*}{\multicolumn{2}{|c|}{ 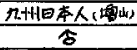 }} & \multirow{2}{*}{\multicolumn{2}{|c|}{ 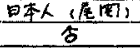 }} & \multirow{2}{*}{\multicolumn{2}{|c|}{ 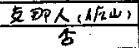 }} \\
\hline & & & & & & & \\
\hline & & 12 & $\%$ & & gs & 25 & $\%$ \\
\hline \multirow[t]{2}{*}{$\underset{\text { 补 }}{F}$} & 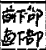 & & $\begin{array}{r}75,0 \times 12.50 \\
8.3 \pm 7.96\end{array}$ & & & & \\
\hline & to & 10 & & 26 & $578=33 b$ & 21 & $840=234$ \\
\hline (yin & $\bar{n}$ & 2 & 0.77 & $\frac{11}{8}$ & $\begin{array}{l}24,4 \pm 640 \\
17.8 \pm 5,70\end{array}$ & & \\
\hline
\end{tabular}

形状；表 34 に示すように，円形 $41.7 \%$ ，棈円形 $58.3 \%$ と九州日本人男子では棈円形のものがや」多 いのに反し，支那人男子では円形 $68.0 \%$ ，棈门形 $32.0 \%$ と円形の青のが多い.

表 34 甲状軟霄孔形状比较

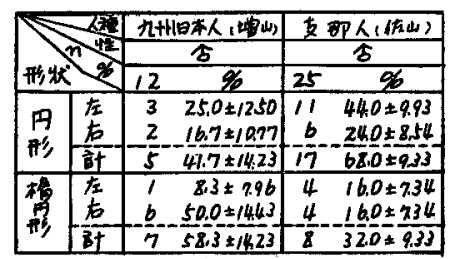

16）左右失衡

九州日本人では 6 例 (12.0\%) の左右失衡を認め，こ れはすべて男性 $(22.0 \%)$ において諰められたもので， 支那人男子の 5 例 $(10.0 \%)$ に比し高率を示し，欧洲人 
の 25.0\% (Scheek) に較べや>低率である.

奏 35 左右失街比較

\begin{tabular}{|c|c|c|c|}
\hline$人$ 校 & 朝告音 & 古䄪关出 & 左板㚣出 \\
\hline nitiotx & 管 & 6 侈 & 0 \\
\hline 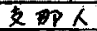 & 传山 & 4 & 1 \\
\hline 日本人 & $\begin{array}{ll}0 \\
4\end{array}$ & $\begin{array}{r}15 \\
5\end{array}$ & 2 \\
\hline $\begin{array}{c}\text { 欧洲人 } \\
Z_{\text {Zuck }}\end{array}$ & $\begin{array}{l}\text { Waldeyer } \\
\text { shande }\end{array}$ & $\begin{array}{c}5 \\
10 \\
16\end{array}$ & $\begin{array}{l}4 \\
4\end{array}$ \\
\hline
\end{tabular}

更に左右両板の突出を比較すると，表 35 に示すよう に全人種において右板突出が多く，九州日本人では左板 突出は 1 例も見られなかつた。

17) 麦粒小体

麦粒小体の存在は表 36 に示すように，九州日本人， 支那人，欧洲人共に大差なく，三者共两側に存在するむ のが多い.

表 36 麦粒小体比軷

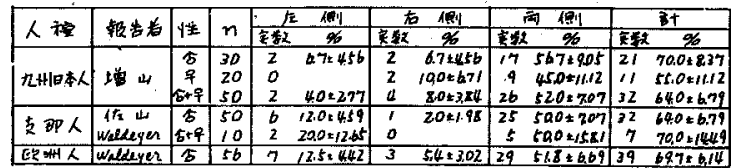

\section{2. 桷状軟胃について}

1) 上口径（表 37）

i）矢状径：男性は平均 $30.5 \mathrm{~mm}$ で支那人，九州日 本人，台湾蕃人，欧洲人，日本人 (尾関) の順に大きく， 女性は平均 $24.4 \mathrm{~mm}$ で台湾蕃人，日本人 (尾関)上り 大である・

ii）横径：男性は平均 $20.4 \mathrm{~mm}$ で矢状径同様支那人 に次ぎ，女性は平均 $15.6 \mathrm{~mm}$ で九州日本人が最も大で ある・

表 37 上口径比较 (単位 $\mathrm{mm}$ )

\begin{tabular}{|c|c|c|c|c|c|c|c|c|c|}
\hline \multirow{2}{*}{ 人喍 } & \multirow{2}{*}{ 啈告者 } & \multirow{2}{*}{ 性 } & \multirow{2}{*}{$n$} & \multirow{2}{*}{\multicolumn{3}{|c|}{ 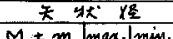 }} & \multicolumn{3}{|c|}{$76 \quad x$} \\
\hline & & & & & & & $M \pm m$ & mex. & $\min$. \\
\hline 九州日本人 & 增山 & 占 & $\begin{array}{l}30 \\
70\end{array}$ & $\begin{array}{l}30,5 \pm 0.30 \\
244 \pm 0.38\end{array}$ & $\begin{array}{l}350 \\
280\end{array}$ & $\begin{array}{l}260 \\
220\end{array}$ & $20.4 \times 0.31$ & $\begin{array}{l}250 \\
190\end{array}$ & $\begin{array}{l}170 \\
120\end{array}$ \\
\hline 台㴒畐人 & A w & 古 & $\begin{array}{c}4 \\
1\end{array}$ & 25.29 & $26 \mathrm{SW}^{2}$ & 2265 & (1/16/6 & 1975 & $n, t s$ \\
\hline 支 & $1 / 2 山$ & $\widehat{s}$ & 50 & $22.1 \pm 420$ & 35.0 & 280 & $226 \pm 0.31$ & 2,0 & 1990 \\
\hline 日本人 & 尾消 & 㔬 & $\begin{array}{l}b 0 \\
43\end{array}$ & 2326 & $\begin{array}{l}35,0 \\
25,0\end{array}$ & $\begin{array}{l}77.0 \\
100\end{array}$ & $\begin{array}{l}275 \\
145\end{array}$ & $2 a 0$ & 12.0 \\
\hline Ex $3 x$ & Luschlea & $\frac{1}{5}$ & & 246 & & & & & \\
\hline
\end{tabular}

2) 下口径 (表 38)

i）矢状径：男性は平均 $20.8 \mathrm{~mm}$ で，支那人よりや や小で，欧洲人，日本人（尾関）台湾蕃人に較べ大であ る・性は平均 $17.0 \mathrm{~mm}$ で台湾蕃人上り大である・

ii）横径：男性は平均 $21.9 \mathrm{~mm}$ で支那人よりや小 で，台湾蕃人上り大である・女性は平均 $17.2 \mathrm{~mm}$ で台
湾蕃人より大である：

表 38 宁口径比軽 (単位 $\mathrm{mm}$ )

\begin{tabular}{|c|c|c|c|c|c|c|c|c|c|}
\hline & & & & 卖 & $x \cdot 1 \frac{x}{2}$ & & 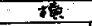 & 狌 & \\
\hline 人 & 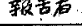 & $r^{2}$ & $n$ & $M+m$ & mex & $\min$. & $M \pm m$ & $\mathrm{rax}$ & $\min$. \\
\hline$n+H \theta$ 查 & 增 山 & 念 & $\begin{array}{l}30 \\
20\end{array}$ & $\begin{array}{l}20.8 \pm 0.31 \\
17,0 \pm 0.25\end{array}$ & $\begin{array}{l}24.0 \\
19.0\end{array}$ & $\begin{array}{l}18.0 \\
1500\end{array}$ & $\begin{array}{l}21.9 \pm 0.31 \\
172=0.34\end{array}$ & {$\left[\begin{array}{l}240 \\
260\end{array}\right.$} & {$\left[\begin{array}{l}79.0 \\
15.0\end{array}\right.$} \\
\hline 台湦曾人 & 加山 & $\begin{array}{l}1 \\
5 \\
4\end{array}$ & 4 & $\begin{array}{l}15,88 \\
13,15\end{array}$ & 7780 & 12.10 & $\begin{array}{l}1828 \\
1540\end{array}$ & 79.65 & 16,10 \\
\hline 政人 & 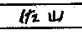 & 吕 & 50 & $21.7 \pm 0.26$ & 25.0 & 17.0 & $22,5=0,24$ & 25.0 & 18.0 \\
\hline 日本人 & 尾阅 & $\begin{array}{l}\text { 合 } \\
+\end{array}$ & $\begin{array}{l}60 . \\
43\end{array}$ & $\begin{array}{l}175 \\
125\end{array}$ & $\begin{array}{r}20.0 \\
15,0\end{array}$ & $\begin{array}{r}200 \\
50 \\
\end{array}$ & & & \\
\hline 欧洲 $\mathrm{K}$ & duschka & 5 & & 19.0 & & & & & \\
\hline
\end{tabular}

表 39 弓高径及び板中央高径比糢（算位 $\mathrm{mm}$ )

\begin{tabular}{|c|c|c|c|c|c|c|c|c|c|c|}
\hline \multirow{2}{*}{ 人糧 } & \multirow{2}{*}{ 辂告者 } & \multirow{2}{*}{ 性 } & \multicolumn{4}{|c|}{ 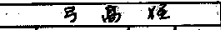 } & \multicolumn{4}{|c|}{ 板中央白悎 } \\
\hline & & & $n$ & $M \pm m$ & max. & $\min$. & $n$ & $M \pm m$ & $\max$. & $\min$. \\
\hline nHH体人 & 增山 & 古 & $\begin{array}{l}30 \\
20\end{array}$ & $\begin{array}{l}6.1 \pm 0.18 \\
4.4 \pm 0.15\end{array}$ & $\begin{array}{r}9.0 \\
6.0\end{array}$ & $\begin{array}{l}6.0 \\
40\end{array}$ & $\begin{array}{l}30 \\
20\end{array}$ & $\begin{array}{l}21.7 \pm 0.24 \\
18.3 \pm 0.31\end{array}$ & $\begin{array}{l}2510 \\
20,0\end{array}$ & $\begin{array}{l}19.0 \\
1,0\end{array}$ \\
\hline 台清局人 & A山 & 亲 & 4 & $\begin{array}{l}5.63 \\
4.60 \\
\end{array}$ & 6.60 & 450 & $\begin{array}{l}4 \\
2\end{array}$ & $\begin{array}{l}20.04 \\
20.08\end{array}$ & $\begin{array}{l}20025 \\
2320 \\
\end{array}$ & $\begin{array}{l}19.60 \\
189.95\end{array}$ \\
\hline 妾DPA & $1 \sqrt{2}$ is & 5 & 50 & $b, / \pm 0,18$ & 10.0 & 4.0 & 50 & $22.6 \pm 0.21$ & 26.0 & Ira: \\
\hline 曰本人 & 在同 & 点 & $\begin{array}{l}60 \\
43\end{array}$ & $\begin{array}{l}6.5 \\
50 \\
.0\end{array}$ & $\begin{array}{l}10.0 \\
10.0 \\
\end{array}$ & $\begin{array}{l}5.0 \\
4.0\end{array}$ & $\begin{array}{l}60 \\
43 \\
\end{array}$ & $\begin{array}{l}21.5 \\
1.5 \\
\end{array}$ & $\begin{array}{l}250 \\
2000 \\
\end{array}$ & $\begin{array}{l}\text { isp } \\
\text { rto }\end{array}$ \\
\hline$E x=41 \alpha$ & $\begin{array}{l}\text { Lusuke } \\
\text { CiL.Me } \\
\text { Fr.Met }\end{array}$ & & & $\begin{array}{l}70 \\
7.0 \\
7.028 .0\end{array}$ & & & & $\begin{array}{l}19.0-23,0 \\
1200 \\
10.0-23,0\end{array}$ & & \\
\hline
\end{tabular}

3) 弓高径 (表39)

男性恃平均 $6.1 \mathrm{~mm}$ で，支那人，日本人（尾関）， 台湾蕃人に比較し全く一致するか，又は大差を認め ない.女性は平均 $4.9 \mathrm{~mm}$ で，他人種と殆えど差 異を認めない。打欧洲人においては性別不明であ。 るが，いずれ汇せよ他人璉より大゙である。

4）板中央高径 (表 39)

男性は平均 $21.7 \mathrm{~mm}$ で支那人よりや小小であるが， 日本人（尾関）とは殆んど一致し，台湾蕃人より大であ. る. 女性は平均 $[8.3 \mathrm{~mm}$ で支那人，台湾蕃人上りや」 小で，日本人 (属関) とは殆しど一致している・な就欧 洲人は他人種に比し性別は不明であるがや」大である。

5）披裂関節面内端より下緑迄の距離（表 40） 男性は平均 $22.7 \mathrm{~mm}$ で支那人と大差を認めない。

表 40 披裂関節面內外端より下線运の距離比较 (单位 $\mathrm{mm}$ )

\begin{tabular}{|c|c|c|c|c|c|c|c|c|c|}
\hline \multirow{2}{*}{ 人裡 } & \multirow{2}{*}{ 软告看 } & \multirow[b]{2}{*}{ 性 } & \multirow{2}{*}{$n "$} & \multicolumn{3}{|c|}{ 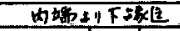 } & \multirow{2}{*}{\multicolumn{3}{|c|}{ 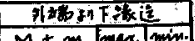 }} \\
\hline & & & & $M \pm m$ & 1 max. & $\min$. & & & \\
\hline & 增山 & $\begin{array}{l}\text { 昘 } \\
\&\end{array}$ & $\begin{array}{l}30 \\
20\end{array}$ & $\begin{array}{l}22,7 \pm 0.20 \\
19.4 \pm 0,17\end{array}$ & $\begin{array}{l}240 \\
220\end{array}$ & $\begin{array}{l}200 \\
170\end{array}$ & $\begin{array}{l}172 \pm 0.18 \\
143 \div 0.19\end{array}$ & $\begin{array}{l}21.0 \\
18.0\end{array}$ & $\begin{array}{c}15.0 \\
13.0\end{array}$ \\
\hline$\{2$ & di坓山 & $\frac{1}{5}$ & 50 & $23.6 \pm 0.14$ & 27.0 & 20.0 & $129=0.13$ & $z i a$ & 1,140 \\
\hline
\end{tabular}

6）披裂関節面外端より下縁迄の距離（表 40）

男性は平均 $17.2 \mathrm{~mm}$ で支都人と殆んど一致している。

7) 最大横径 (表 41)

男性は平均 $27.5 \mathrm{~mm}$ で爷那人よりやつ小で，日本人 （尾関）上りや小大である・姓は平均 $21.3 \mathrm{~mm}$ で矢張り日本人 (㞘開)上り大である。 
表 41 最大横径及び周径比较（单位 $\mathrm{mm}$ )

\begin{tabular}{|c|c|c|c|c|c|c|c|c|c|}
\hline $1 \rightarrow$ & 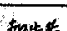 & 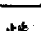 & $m$ & 霞太 & 䅞 $x$ & & 周 & $\bar{x}$ & \\
\hline & 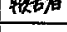 & $\sqrt{2}$ & $n$ & $M \pm M$ & minas. & mine. & $M \pm m$ & max. & $\min$ \\
\hline 九圤日本人 & 增山 & 含 & $\begin{array}{l}30 \\
20 \\
\end{array}$ & $\begin{array}{r}27.5 \pm 0,43 \\
21,3 \pm 0,32 \\
\end{array}$ & $\begin{array}{l}32,0 \\
24,0 \\
\end{array}$ & $\begin{array}{r}23.0 \\
19.0 \\
\end{array}$ & $\begin{array}{l}82.0 \pm 0.91 \\
00.4 \pm 0.83\end{array}$ & $\begin{array}{l}90.0 \\
72.0\end{array}$ & $\begin{array}{l}73,0 \\
620\end{array}$ \\
\hline CNA & th山 & t) & 50 & $28,1 \pm 0.23$ & $\frac{2430}{33,0}$ & 250 & $81.9 \times 0.83$ & 44.0 & $\frac{5.0}{40,0}$ \\
\hline 日南人 & 尾闲。 & $\begin{array}{l}0 \\
\text { 年 }\end{array}$ & $\begin{array}{l}60 \\
43\end{array}$ & $\begin{array}{l}25.0 \\
18.5\end{array}$ & $\begin{array}{l}35.0 \\
25.0\end{array}$ & $\begin{array}{l}18.0 \\
16,0\end{array}$ & & & \\
\hline
\end{tabular}

8）披裂関節面内端間距離（表: 42）

男性は平均 $12.6 \mathrm{~mm}$ で日本人(尾笑)とは殆えど一致 し，支那人よりや」小である。

表 42 披裂関解面內 - 外端間距離比較（単位 $\mathrm{mm}$ )

\begin{tabular}{|c|c|c|c|c|c|c|c|c|c|}
\hline \multirow{2}{*}{ 楻 } & \multirow{2}{*}{ 都告者 } & \multirow{2}{*}{ 性 } & \multirow[b]{2}{*}{$n$} & \multicolumn{3}{|c|}{ 内箅向距峦 } & \multicolumn{3}{|c|}{ 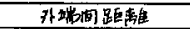 } \\
\hline & & & & $M \pm m$ & mex. & $\min$ & $M \pm m$ & $\max$. & $\min , 1$ \\
\hline 几州輣人 & 增山 & $\begin{array}{l}\text { 昘 } \\
\text { 兵 }\end{array}$ & $\begin{array}{l}30 \\
20\end{array}$ & $\begin{array}{r}12.6 \pm 0.24 \\
9.9 \pm 0.24\end{array}$ & $\begin{array}{l}15.0 \\
12.0\end{array}$ & $\begin{array}{l}8.0 \\
8.0\end{array}$ & $20,9=0.23$ & 240 & $\begin{array}{l}18.0 \\
15.0\end{array}$ \\
\hline 妾DP & 科山 & 客 & 50 & $1.28 \pm 0.20$ & 17.0 & 11.0 & $21.6 \pm 0.17$ & 2400 & 19.0 \\
\hline 日本人 & 尾夏 & 舍 & $\begin{array}{l}60 \\
43\end{array}$ & $\begin{array}{c}12.5 \\
9.0 .\end{array}$ & $\begin{array}{l}77.0 \\
3.0\end{array}$ & $\begin{array}{c}10,0 \\
80\end{array}$ & & & \\
\hline
\end{tabular}

9）披裂関節面外端間距離（表 42）

男性は平均 $20.9 \mathrm{~mm}$ で支那人よりや小小である。

10) 周径 (表 41)

男性は平均 $82.0 \mathrm{~mm}$ で支佛人と殆えど一致している。

11）披裂閣飾面 (表 43)

i）紸径：男性は平均 $6.5 \mathrm{~mm}$ で日本人（尾間）とは 全く一致し，支那人より小で台湾蕃人よりや〉大であ る・女性は平均 $5.4 \mathrm{~mm}$ で日本人（尾関）とは殆えど大 差なく台湾蕃人より小である。

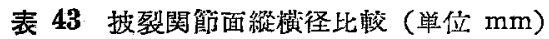

\begin{tabular}{|c|c|c|c|c|c|c|c|c|c|}
\hline & & & & s & $x$ & & 䅦 & $x_{2}^{4}$ & \\
\hline & & $v$ & $n$ & $M \pm m$ & $\max$. & mins. & $M \pm m$ & $\max$. & mins. \\
\hline & 增山 & 舍 & $\begin{array}{l}30 \\
20 \\
\end{array}$ & & $\begin{array}{l}4.0 \\
7.0 \\
\end{array}$ & $\begin{array}{l}5.0 \\
40 \\
\end{array}$ & $\begin{array}{l}3.6 \pm 0,07 \\
3,1 \pm 0,08\end{array}$ & $\begin{array}{l}53 \\
4.0 \\
\end{array}$ & $\begin{array}{l}3,0 \\
2.0 \\
\end{array}$ \\
\hline 㟔清覩人 & A山 & $\begin{array}{l}\text { 客 } \\
+\end{array}$ & & & $\begin{array}{l}0.55 \\
0.60\end{array}$ & $\begin{array}{l}5700 \\
425\end{array}$ & & $\begin{array}{l}4.15 \\
365\end{array}$ & $\begin{array}{l}245 \\
260\end{array}$ \\
\hline 交那人 & 传山 & 宫 & 5 & $9+2,2 b$ & 9.0 & 5,0 & $40 \neq a$ & 6.0 & 30 \\
\hline 日本 & 尾闾 & 龺 & & & $\begin{array}{l}8.0 \\
0.0\end{array}$ & $\begin{array}{l}0.0 \\
40\end{array}$ & $\begin{array}{l}4.5 \\
3, c\end{array}$ & 6.0 & 30 \\
\hline
\end{tabular}

ii）横径：男性梳均 $3.6 \mathrm{~mm}$ で日本人(尾咸)，支 那大に比较して小で，合湾蕃人よりや」大である・文性 は平均 $3.1 \mathrm{~mm}$ で三者共大差を認めない。

12) 甲状唒節面 (表 44)

i）縱堡：男性は平均 $4.6 \mathrm{~mm}$ で支那人よりや」 大であるが，台湾蕃人に較べ小である・女性は平均 $4.2 \mathrm{~mm}$ で台湾蕃人より小である。

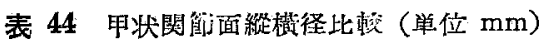

\begin{tabular}{|c|c|c|c|c|c|c|c|c|c|}
\hline \multirow[b]{2}{*}{ 人種 } & \multirow[b]{2}{*}{ 蜁告看 } & \multirow[b]{2}{*}{ 性 } & & \multicolumn{3}{|c|}{$x$} & \multicolumn{3}{|c|}{ 椎 澄 } \\
\hline & & & & $M \pm m$ & manex. & min. & $M \pm m$ & mex & \\
\hline & & 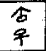 & & & $\begin{array}{l}6.0 \\
6.0 \\
\end{array}$ & $\begin{array}{l}3.0 \\
3.0\end{array}$ & & $\begin{array}{l}6.0 \\
60\end{array}$ & $\begin{array}{l}3.0 \\
3,0\end{array}$ \\
\hline & & & & & $\begin{array}{l}0.00 \\
4.80\end{array}$ & $\begin{array}{l}450 \\
4935\end{array}$ & & $\begin{array}{l}5,20 \\
405\end{array}$ & $\begin{array}{l}3.30 \\
3.05\end{array}$ \\
\hline A & $2 \psi$ & 8 & & $42 \pm 0.11$ & 6.2 & 2.0 & $4.1 \pm 0.09$ & 6.0 & 2.0 \\
\hline
\end{tabular}

ii) 横径：男性奻平均 $4.5 \mathrm{~mm}$ で支那人，台湾蕃人 よりや」大で，女性も文平均 $4.1 \mathrm{~mm}$ で台湾蕃人より大 である・

以上輪状軟算計測值に和子る性別では，合湾蕃人の1 〜2 の部位を除いて九州日本人，日本人（尾関）共にす ベて男性が女性より懮つている。

13）披裂闒節面形態（表 45）

尾関は日本人 83 例中骨淢形を呈したるのは1例（1.2 \%)で，他はすべて棈円形であると言い，佐山は支那人 男子 50 例中秷円形を呈したものは 1 例 (2.0\%) で，他 はすべて腎臓形を量すると言い，両者全く趣を異にして おるが，䇠者の調查例では男女共腎臓形を呈するものが 過半数を示して最も多く、棈円形はこれに次ぎ，一侧緊蔵 形で他側は楕円形を呈するものが文少数認められる・徥 つて筆者の成續はさしろ佐山の支那人の成續江類似し， 尾閣の日本人とは趣を異にする。

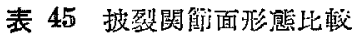

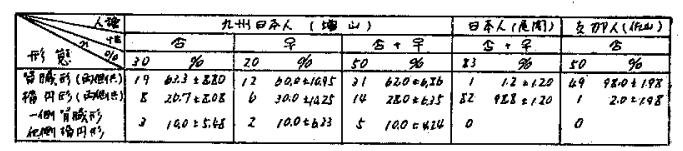

14）甲状関節面 (表 46)

甲状䦔閏節面の久如するものは本群では 15 例 $30.0 \%$ ， 日本人 (尾関) では $34.9 \%$ で, 両者間に大差なく, 男女 間では耐者共に女性に颃いて欠如するものが多き傾きが

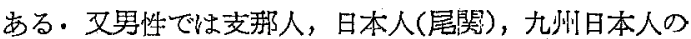
順序で，甲状関節面の欠如は日本人に和いては支那人の 約半数を示している。

更に側別を観察すると，九州日本人，日本人（尾関）， 支那人のすへて両者共炕久如するものが多く，九州日本 人では右側のみに攵如するものは1例子諗めとれなから た.

表 46 甲状関解面欠如弶比䡈

\begin{tabular}{|c|c|c|c|c|c|c|c|c|c|c|}
\hline 神 & & r里 & & & 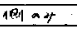 & & $189=4$ & & 红 & $B T$ \\
\hline 274 & 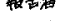 & $\sqrt{2 x}$ & ? & 安教 & $\%$ & 政 & 90 & 等 & 96 & 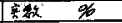 \\
\hline 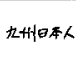 & 嫂山 & $\begin{array}{l}5 \\
7 \\
7\end{array}$ & $\begin{array}{l}30 \\
z 0\end{array}$ & & $\begin{array}{l}10.0+5,45 \\
25,3 \times 9.9\end{array}$ & 0 & & & $\begin{array}{l}10.0 \pm 5.48 \\
20.0 \pm 894\end{array}$ & $\begin{array}{ll}6 & 20,0=430 \\
9 & 45,0 \pm 1114\end{array}$ \\
\hline \multirow{3}{*}{ 日本人。 } & & & & & $0.7 \pm 1.73$ & & & & & $229 \pm 703$ \\
\hline & 俈闻 & $\frac{q}{p+q}$ & 28 & ; & & 5 & $\begin{array}{r}1,22=5,50 \\
8.4+30,05\end{array}$ & $\begin{array}{l}12 \\
19\end{array}$ & $\begin{array}{l}32.6 \times 254 \\
22.9 \pm 462\end{array}$ & $\begin{array}{l}447 \times 28 \\
349+52\end{array}$ \\
\hline & & & & & & & & & & $0.0 \pm 7$ \\
\hline
\end{tabular}

15）輸叫軟骨·板部形状

i）板部示標：（表47）二檑の示標を用いた。

2. 広心示標；九州日本人，支那人，欧洲人共に示標71 〜 80 が最も多く，その任現率も殆んど近似しているが， 一般に安那人は九州日本人，欧洲人より示標の大なるる 
のが多く，これは支那人が他の二人種に比皎して甲状関 節突起の発育形成が軽度である事を示するのである・

表 47 輸状顿督板部示標比较

\begin{tabular}{|c|c|c|c|c|c|c|c|c|c|}
\hline \multirow{3}{*}{\multicolumn{2}{|c|}{${ }_{7}=\frac{12}{6}$}} & \multirow{2}{*}{\multicolumn{2}{|c|}{ 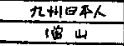 }} & \multicolumn{4}{|c|}{ \& } & \multirow{2}{*}{\multicolumn{2}{|c|}{ 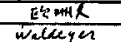 }} \\
\hline & & & & \multirow{2}{*}{\multicolumn{2}{|c|}{$\frac{\pi \sqrt{2}}{5}$}} & \multirow{2}{*}{\multicolumn{2}{|c|}{$\frac{w a l l o g}{5}$}} & & \\
\hline & & \multicolumn{2}{|r|}{ 占 } & & & & & \multicolumn{2}{|c|}{$\frac{1}{5}$} \\
\hline & & 30 & $\%$ & 50 & $\%$ & & 96 & $\omega$ & $\%$ \\
\hline & $b 1 \sim 70$ & 7 & $233 \pm 772$ & 3 & 0.06 .5 & 0 & & 8 & $18.6 \pm 429$ \\
\hline$t_{4} 227$ & $31-20$ & 17 & $507 \div 406$ & 25 & $70.0 \times 4.45$ & $\boldsymbol{x}$ & $20.0 \pm / 2.65$ & 28 & $651: 127$ \\
\hline & $21-40$ & 6 & $=7.30$ & 12 & $24.0=645$ & $z$ & $200+12.45$ & 7 & $(0,\{\leq 5,6]$ \\
\hline & $41-80$ & ' & 2.26 & 2 & & & & 3 & 70.3 .59 \\
\hline & $x / \sim 40$ & 1 & $36.7 \div 280$ & 19 & $38: 0 \pm 426$ & 9 & $900 \div 9.49$ & 23 & t5:t $=761$ \\
\hline & $\begin{array}{l}91 \sim 100 \\
100 \times<k\end{array}$ & 17 & $50.7 \pm 802$ & 29 & $520 \times 498$ & 0 & & 17 & $39.5 \pm 7.46$ \\
\hline
\end{tabular}

b. 高広示標；九州日本人，支那人では示標 91 100 が過平数を占めている・即らこの示標は前述したように 主として板部気営輪状軟骨の形態が細長いかあるいは横 広いかを示するのであり，九州日本人，支那人は欧洲人 の夫礼よりや短くしかも広い事を示している。

ii）上下縁：（表 48）男性では上下両縁共に九州日本 人, 日本人(尾関)，支那人のいずれも陷凹したものが最 も多いが，九州日本人は他の二者に比してや小骝凹した むのが少なく，平坦なるのが多くなつている・不下縁と

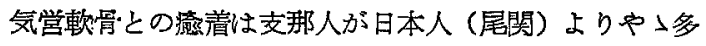
く，九州日本人では1例も認められなかつた・

表 48 輸状軟骨板上下線比校

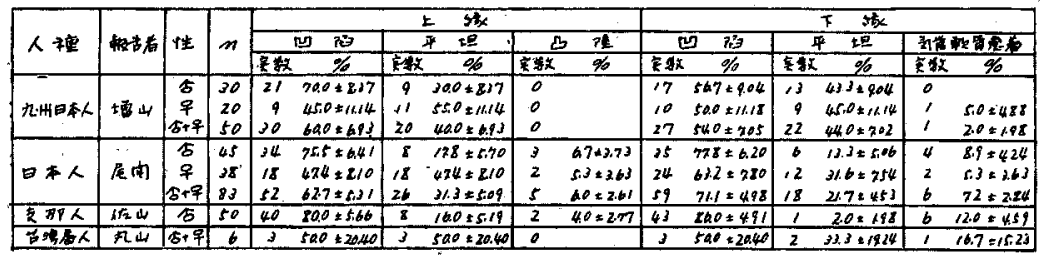

女性では上縁の陥凹したるの及び平坦なすのが九州日 本人で後者の方にや小多いが，日本人 (尾閏) では平 坦なものが陮凹したもの半数を示している・更に下縁 之気営軟骨之の䈍盖は九州日本人，日本人 (尾関) 共比 少数である・

な打台湾蕃人の場合は例数が少ないため，比較の対象 とせず参考として記載した・

16）輪状軟骨と気営輪との湔着

輪状軟骨と気営輪との溹着は Merkel, Henle 等が特

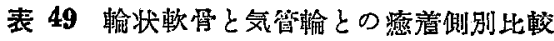

\begin{tabular}{|c|c|c|c|c|c|c|c|c|c|}
\hline \multirow{2}{*}{ 人樓 } & \multirow{2}{*}{ 鞎告有 } & \multirow{2}{*}{ 性 } & \multirow{2}{*}{$n$} & \multicolumn{3}{|c|}{ 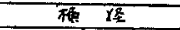 } & \multicolumn{3}{|c|}{ 专视 } \\
\hline & & & & $M \pm \sin$ & max. & $\min$. & $M \pm m$ & $\max$. & $\min$. \\
\hline & 增山 & $\begin{array}{l}\text { 合 } \\
\text { 平 }\end{array}$ & $\begin{array}{l}30 \\
20\end{array}$ & & $\begin{array}{l}70 \\
50\end{array}$ & $\begin{array}{l}40 \\
40\end{array}$ & $\begin{array}{l}49 \pm 0.07 \\
42 \pm 0.07\end{array}$ & $\begin{array}{l}0.0 \\
5.0\end{array}$ & $\begin{array}{l}40 \\
30\end{array}$ \\
\hline & & $\begin{array}{l}\text { 今 } \\
\text { 車 }\end{array}$ & $\begin{array}{l}4 \\
2\end{array}$ & $\begin{array}{l}459 \\
484\end{array}$ & $\begin{array}{l}5.85 \\
5.65\end{array}$ & $\begin{array}{l}3.95 \\
4.10\end{array}$ & $\begin{array}{l}6.13 \\
4.74\end{array}$ & $\begin{array}{l}5.65 \\
5.20\end{array}$ & $\begin{array}{l}4.55 \\
4,35\end{array}$ \\
\hline $5 D P K$ & d/2 & 5 & 50 & $6.1 \div 0.02$ & 8.0 & 5.0 & 52 & 70 & 3.0 \\
\hline
\end{tabular}

に注意した所であつて，尾関は又日本人においてや小多 数にこれを認め，佐山も支家人男子において，Waldeyer る又欧洲人に就いてこれを展及認めている。

筆者の調查した成績を他人頻と此較すれば，表 $49 \mathrm{~K}$ 示すよらに，支那人に最る多く次いで欧洲人，日本人 (尾関) 更び九州日本人と日本人に战いて最も少ない。

性別；九洲日本人，日本人 (尾関) 共嵝男性より女性 にや」多数認めている.

側別；各人種共に左側汇認めるものが多く，右側に は少ない，但し同側に㒛めるすのが欧洲人に多いようで ある・

渼着部位；表 50 に示すように，環部のみとの滑着が 各人種共に多くすべて一致している。

表 50 輸状軟骨と気営輸との㾊着部位比戟

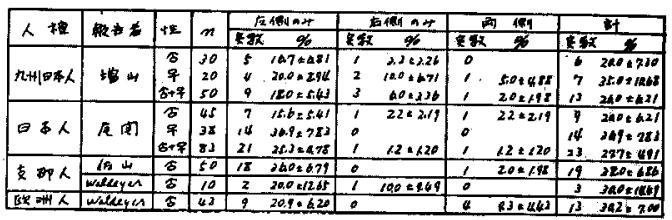

3. 披裂軟肯について

1) 披裂軟量高径(表51)

男性任平均 $13.8 \mathrm{~mm}$ で， 支䛍人，台湾蕃人より小さ く，女性も又台湾蕃人より小 である・

2）輪状関節面 (表52)

i）縦径；男性は平均 4.9 $\mathrm{mm}$ で支那人，合湾蕃人よりや」小である・女性は平 均 $4.2 \mathrm{~mm}$ で台敦蕃人より小である.

表 51 披裂軟胥演径比戟

\begin{tabular}{|c|c|c|c|c|c|c|c|c|c|}
\hline \multirow{2}{*}{ 人祀 } & \multirow{2}{*}{ 澉告有 } & \multicolumn{4}{|c|}{ 杏 } & \multicolumn{4}{|c|}{ 平 } \\
\hline & & $n$ & $M \pm m$ & $\max x$ & $\min$. & & $M \pm m$ & mM. & \\
\hline 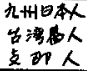 & 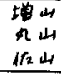 & $\begin{array}{r}30 \\
4 \\
50\end{array}$ & $\begin{array}{l}13.8 \pm 0.29 \\
14.93 \\
5.1 \pm 0.10\end{array}$ & \begin{tabular}{|l|}
17.0 \\
16.55 \\
170
\end{tabular} & $\begin{array}{c}40 \\
13,00 \\
110\end{array}$ & $\begin{array}{r}20 \\
2\end{array}$ & $\begin{array}{l}11.6 \div 0.15 \\
1493\end{array}$ & $\begin{array}{l}14.0 \\
1685\end{array}$ & $\begin{array}{l}10.0 \\
1,3,95\end{array}$ \\
\hline
\end{tabular}

表 52 輪状関简了面横程径比較

\begin{tabular}{|c|c|c|c|c|c|c|c|c|c|}
\hline \multirow{2}{*}{ 人视 } & \multirow{2}{*}{ 银告龙 } & \multirow{2}{*}{ 性 } & \multirow[b]{2}{*}{$n$} & \multicolumn{2}{|c|}{ 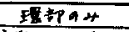 } & \multicolumn{2}{|c|}{ 1648k1ktp } & \multicolumn{2}{|r|}{ It } \\
\hline & & & & 教 & $\%$ & 实 & 4 & 安邫 & 8 \\
\hline 九H呠人 & 增山 & $\begin{array}{c}5 \\
5 \\
+ \\
5+9\end{array}$ & $\begin{array}{l}20 \\
20 \\
50\end{array}$ & $\begin{array}{l}6 \\
6 \\
6 \\
12\end{array}$ & $\begin{array}{l}20.0 \pm 230 \\
30.0 \pm 10.25 \\
24.0 * 0.43\end{array}$ & 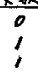 & $\begin{array}{l}50 \pm \quad 188 \\
20 \pm 18 x\end{array}$ & $\begin{array}{c}6-16 \\
7 \\
13\end{array}$ & $\begin{array}{l}20.0 \pm 730 \\
3510 \pm / a 68 \\
26.0 \pm 021\end{array}$ \\
\hline & 尾阁 & 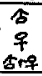 & $\begin{array}{l}45 \\
38 \\
83 \\
\end{array}$ & $\begin{array}{l}9 \\
14 \\
23\end{array}$ & $\begin{array}{l}20.0 \pm 5.97 \\
348 \times 782 \\
277 \pm 4.91\end{array}$ & $\begin{array}{l}5 \\
3 \\
5\end{array}$ & $\begin{array}{l}11.0 \pm 4.68 \\
79: 4.37 \\
9.6 \pm 3,24\end{array}$ & $\begin{array}{l}14 \\
17 \\
31\end{array}$ & $\begin{array}{l}311 \times 690 \\
447 \pm 897 \\
323 \pm 531\end{array}$ \\
\hline \&D大 & 侑山 & 令 & 50 & 13 & $26,0 \pm 6,21$ & 6 & $12.0 \times 4.59$ & 19 & $3 x 0=6 x b$ \\
\hline
\end{tabular}

ii）横径；男性は平均 $5.3 \mathrm{~mm}$ で支制人より小で台 湾蕃人より大である.女性は平均 $4.5 \mathrm{~mm}$ で台湾蕃人よ 


\section{り小である・}

4. その他の軟骨炬ついて

\section{1) 膽頭蓋軟骨}

前述のように喉頭蓋軟骨の形態を $a, b, c, d, e$ の 5 型（図 1. 参照）に分類したが，これは松島の分類の $\mathrm{A}$,

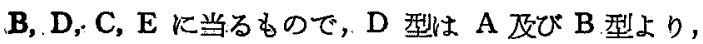
又、 $\mathrm{E}$ 型は $\mathrm{C}$ 型より誘発せられるものであると考光ら れると記戴しているように，その型よりして筆者は D 型はむしろ $\mathrm{c}$ 型とし，C 型を $\mathrm{d}$ 型として 比較観察し た・

\section{表 53 喉頭藍軟骨形䉥比䡌}

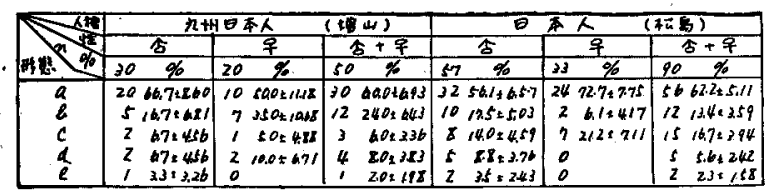

即ち表 53 に示すように，両者共 $a$ 型が最む多く過半 数を占め, 以下九州日本人では $b, d, e$ の順であるが， 松島の場合は $c, b, d, e$ の順となり, 両者共 $\mathrm{a}$ 型が最 む多く，e 型が最む少なく，以下多少の增減はあっても b, c, d 型は $1 / 3$ 前後を占め, 両者殆えど類似してい る.

2）小角軟霄:

九州日本人，支那人共に全例に打いて認め，その大き さも夫そ大差を認めなかつた。

3）棒 状軟 骨.

筆者の調查例では 50 例中 5 例を数えるのみで，残り の 45例には認められなかつたが，支那人（佐山）では 50 例中 18 例，欧洲人 (Waldeyer) では 56 例中 27 例 を数え，九州日本人の簒状軟骨·の存在は支那人，欧洲人 に比較して少ない上うである・

\section{III・䌊括並びに結論}

九州出身の成人䐅頭男 30 例，女 20 例，計 50 例に拉 ける喉頭軟骨に就いて調查し, 男女の比較は勿論, 欧洲 人，エルザス人，支那人，台湾蕃人あるいは他地方出身 の日本人の成績と比較して，次の結果を得た。

1. 啒頭の全高径並びに甲状軟骨各部の大きさは，上 角の傾斜度，甲状軟骨前角度，上甲状切痕の角以外は男 性が女性より大で，甲状軟管孔の出現率は男女（男性 $36.7 \% \pm 8.80 \%$ ，女性 $35.0 \% \pm 10.67 \%$ ）殆えど大差を諮 めない.

輸状軟骨各部の大きさる同樣男性が女性より大で，披 裂関節面の形態は腎臓形及び棈円形を示し，男女共前者
が多い.甲状関節面の欠如率结男性 20.0\% $07.30 \%$ ，女 性 $45.0 \%$ 土11.14\% で女性は 男性の約 2 倍に相当し，板 部の形状は男性が女性に较べ短広で, 気営軟骨·との瘉着 は女性に多い。

披裂軟骨·各部の大きさも男性が女性より大で，輸状関 節面の縦径はや〉圧平された円形をなするのが多く，横 径はすべて陥凹する。

2. 九州日本人知頭の 全高径並びに甲状軟骨各部の大 きさは，男性では一般に欧洲人より小であり，文支郘人 の夫れとはほら゙同じかや小小で，日本人（尾関）とはは ぼ同じであるが，台湾蕃人に較べて大である・女性では

一般欧洲人，台湾蕃人上り小で，日本人（尾関）之 ほ上゙同じである・即ち一般に男女共白色人種上り優 つている。

性別では九州日本人は上角の傾斜度，甲状軟肯前 角度，上甲状切痕の角を除いてはすべて男性が女性 に優り，日本人（尾関）も又，上角の傾斜度は男女同じ であるが，甲状軟骨前角度及び上甲状切痕の角は女性が 男性より優り，他はすべて男性が優つている・一般欧洲 人では甲状軟骨·前角度において女性が男性より優り，台 湾蕃人では男女夫ょ優劣相半ばする・

3. 上角の欠損は九州日本人では 50 例中 1 例に認めら れたのみで，支那人更び日本人（尾関）と同様欧洲人に 較べ稀のようである。

又甲状軟骨孔の出現率は九州日本人は他地方日本人に 比しゃ〉多く，欧洲人，支那人に較べ少ない.

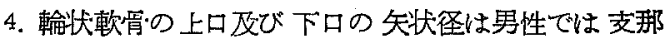
人より小で，欧洲人，日本人（尾䦎）の夫れより大であ る・その他輪壮軟骨·各部の大きさは，一般に男性では支 那人に比し小で，日本人 (尾関)，台湾蕃人の夫れより や〉大であり，女性では日本人 (尾閔)，台湾蕃人に較 ベや」大である.

性別では九州日本人及び 日本人（尾関），台湾蕃人の 1〜2の部位を除いたすべてに扰いて男性は女性より倀 つている。

5. 技裂軟骨・各部の大きさは一般に男性では支那人， 台湾蕃人より小で，女性も又台湾蕃人に較べ小である。

6. 潔状軟骨の存在は爷那人，欧洲人に比較して少な く，小角軟冎は九州日本人，支那人共に全例に誌めた。 文献

第 4 報に゙記载する。 


\section{緒霄}

䐅頭軟虫のの化骨に関しては Vesalius (1555) によ つて研究されて以来，欧米に扣いては Huschke (1844), Luschka (1871), Schotterius (1879), Chievitz (1882) 等の報告があり，更に Scheier (1902), Fränkel (1908), Thost (1913), Weingärtner (1914), Wulfson und Gingsberg (1930) 等の レ線学的研究がある・本 邦においては中山（1908），岡部（1918），松井及び川上 (1923)，保利 (1927)，奥山 (1930)，湯浅 (1938)，稗 田 (1951) 等のレ線学的又組織学的研究, 三上(1930) のキシロー几透明標本による研究がある・有色人種にお いては Grabert (1914) が Hottentott 㤀び Herero 人の䐅頭に就いて例究し，欧洲人に比較し㬋頭軟骨の人 骨は䐅く，50 才前後で停止するためにその程度も甚だ 低いと述べ，又Waldeyer（1926）支䛍人に打いて化胥. は著しく低度であると記載し，佐山(1931)は同様支那人 に就いて調查し白色人と大美を認めないと述べている。

このよらに㬋頭軟胥化晋に関する研究は数多くなさ れ，上線学珀加あるいは組織学的西究，透明標本による 肉眼的観察と凡そ大成された観があるが，大部分は単一 方法による業績で，㒖かに械田が組織学的主びにレ線撮 影の両面よりの矿究を行つているに過ぎない、即ちレ線 学的観察と色調による闪眼的勧察を同時に行つて比較検 討した研究は余り行われていない，従つて筆者は特にこ れ等の点に注意して本研究を行つた・

\section{I. 䃇究材料並ひに研究方法}

研究材料は第 1 報のるのと同一材料を用い，方法汢屍 体より取り出した喉頭諸軟窝ののレ線学:的处見を主とし， 加うるに肉眼的観察では全く軟.婜膜を除去したものに就 いて色調を観察すると共こその便度も針で㭘査し，レ線 学的処見の夫れと比較対照した・即らレ線写真に和いて は諸軟骨をを夫々分離し，甲状軟焉性前角部正中線におい て左右両板を離断し，内面をフィルム面に向け，輸代軟 具においては板部後面をフイルム面に密接させたもの， 及びこれを正中線で切愫し，夫なその内腔をフィルム面 に间けたもの，又披裂軟蛋は左右を並べて夫々撮影し た。

\section{II. 成 績}

1, 甲状軟骨"

1) 21 才〜30才：男性は7例中1例を除いてはすべ てレ線学的に化骨をを認め，最初に出現する化䒿核は下角
基部及び 下角基部後縁に見られ（附図 1)，これと同時 に㕛はや小前後して下甲状結節上り後方一進み下基部 の化胃核と結合し，や>後緑を上昇して L 型の化跨を 認め（附図 2)，同時に下角基部上り漸次進展し，下角 は全く化㱏“する（附図 3). その後下縁のものは下甲状 結節えり前方へ進み且つ下甲状結䬣前部より上方又は上

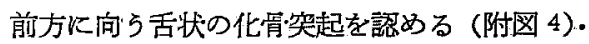

女性は 3 例中寸べてにレ線学的に化穷を諗め，化穼核 は最初に下角基部の後縁に見られ（附図 5)，次いで化

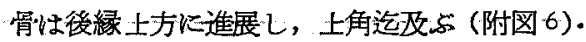

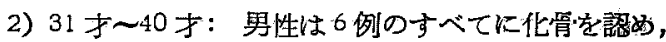
化肯は下角より下縁及び後縁に沿与て進み, 更に前角部 に化霄核出現し，同時に上甲状切痕部にも出現し（附图 7)，これ等は互いに蛤合の傾向にある.

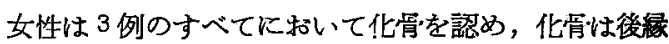
に沿らて軟学板側前方に進及(附図8)，乙かし一部は 下縁に沿らで進展している(附図9).

3） 41 才〜50才：男性はと例の寸へてに化鬲を諰め， この頃になると，上絯にも化㚗核を生じ，上甲状切㡾部 と上縁のものとは互いに融合し，页前時期に拈ける前角 部及び上甲状切痘部に発現した化㱏核と融合し，上縁の 夫れと連絡する（附図 10）・ 又この他下縁より上方（又 は上前方）に出た化骨突起が延長し，同時に媵縁より上 昇して上角に及えでいる（附図 11)。

女性は 4 例のすべてに化盈を認め，化督は板側中央部 八向つて進展し（附図 12），上角基部に一部化骨核を見 るものもある・

4）51 才以上：男性は9 例のすぺてに化㱏を諗め， 化管は下甲状結節部より進展する舌状の化惄突起は上縁 近く迄更び，更に上申状切痕部闭縁に化肯核を生じてや や搪駕している・又更にこれ等が相融合して同時に上角 も後縁より上昇して化骨し（附図 13），又板側前部人軟 骨·島を形成し，後部の軟清·旦も次第に維少与る（(附図 14).

女性は 10 例のすべてに化督を認め，化骨は後縁より すべて前方に進展し，板後部 $1 / 3 \sim 2,3$ は全面的に化骨 するが，板前部は軟監の焦残つている(附図 15)・又こ の他男性の場合に見られるよらな下甲状結節部より板上 方へ舌状の化䆚突起を出しているすの1例（附図 16）を 諗めた・

2. 輪状軟奌. 


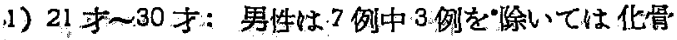

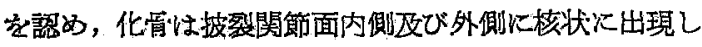
(附図 17)，又披裂関節面外側より発現して内面・外面 のや子摭張し，甲状関節面附近迄及んでいる。

女性は、3 例のすべてに化霄を認め，化管は単に披裂関 節面外側のみ代出現し，内面外面へや>执張を認めるも の，板上縁披裂関節面内側に核状沉出現し，披裂関節面 外側上り内面・外面へや」㹡張し，更に甲状関節面附近 迄進展しているものもある・

2）31 才 40才：男性恃6例のすべてに訨骨を認め， 披裂関節面内側に化霄核あり，外側はや」拨張している が，更に甲状筧節面附近に及び，その上これ等がすべて 連絡しているものが方る(附图 18)。

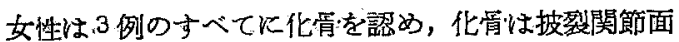
内側核状に出現し，一方披裂閔節面外側より内面・外 面へ及んだすの，更に甲状関節面附近迄及んでいる。

3） 41 オ〜50 才：男性は 8 例のすべてに化筲をを認め，

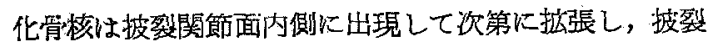
関節面外側は勿論甲状関節面附近に及忙んとしてている。 又更に甲状联節面附近迄進展し，以上が融合して板部及 ぶ弓部上縁に友えでいる(附図 19)。

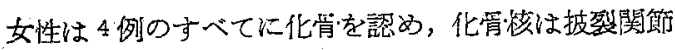
面内側に認め，披裂関節面外側上り内面・外面一及び， 更に甲状筹節面附近迄及んでいる。

4）51 才以上：男性は9例のすべてに化骨を認め， 化骨注披裂関節面府・外側の峏者汇及び，乙かも互いに 融合し，又住融合せずに，更に甲状联節面附近汽進展 乙，板部には進展せず，弓部の一側に及んでいる・文板 部進展しているが，正中線で左右が末だ融合せずに弓

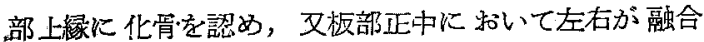
し，弓部に化惄核乃至は化骨かが進展しているものが多い が，弓部に化筒刀出現を認めないるのるある(附図 20).

女性は10例のすべてに化骨を認め，化骨性板上縁左 右の披裂管節面に及び，披裂简節面外側に出現したるの がや子㹡張し，文披裂関節面内側に核状飞認め，披裂関 節面外側上り内面・外面へ及び，更に拡張して甲状閏節 面附近迄及び，又披裂関節面内・外側伍い融合し， 更に甲状翣節面附近迄進展し，又心板部に及んでいるが 正中線で左右が末だ融合しないるの（附図 21），あるい は板部正中に和いて左右が既に融合しているもの（附図 22）がある・な和弓部には全然化管を認めない。

\section{3. 披裂軟督:}

1) $21 \neq \sim 30$ 才：男性性7 例中 1 例，女性は3 例中 l例に叔いて，筋突起部に化筒核の出現を見たのみであ る・

2）31 お〜40 寸：男泩は6例のすべてに，女性は3 例中，2例に化骨を認めた・而して化骨は筋突起部より漸 次上梨して中央部に及九でいる(附図 23).

3） 41 才〜50才：男性は8例のずでてに，女性は4 例中 3 例飞化霄を認め，化霄法三角高の後側迄進展して Wる(附図 24).

4） 51 才以上：男性は9.例の全例保，女性は 10 例中 9 例仁化具を認め，化骨恃男性で三角窝の上界迄達す るものがあり(附図 25)，女性では三角窟の後側迄のむ のが多い(附図 26).

\section{1. 化骨進行状態}

\section{III・・䋓括並びに考按}

1) 甲状軟盈

i）男性：下角基部及び下角基部後縁部汇発見した化 等核は下緑及び後縁汇，又同時に下角にも進展し，前角 部及び上甲状切底部の化骨部之上縁次発現した化管椟は 互いに融合し，更に下緑儿沿らて下甲状結節部に進する ものは，上方又は上前方に進んで所謂舌状刀化骨突起を

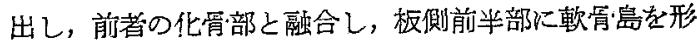
成し，これが濑次維少寸ると同時に，一方後縁汇沿うて 上杽したものは上角より上縁を前進して前者の化管部と 融合し，板側後半部に軟島臂をを形成する・軟皆島は㳄第 儿縮少し，最後には完全に化骨する・

ii）女性：下角基部の後縁汇発胃した化骨核は後縁を 上年し，同時に下緑，板側中央部及び上緑汇沿うて前進 し，板側後部は $1 / 3 \sim 2 / 3$ は完全に 化霄するものと，一 方下角基部の後縁化発見した化骨核は後縁を上算し，同 時に下縁を前進しながら下状線䬦部附近より上前方 へ，丁度男の場合に見られるような化筲突起に類似した 化罠進行状態を示するのとがある・

化霄准行状態沉就いて從来は Huschke，Chievitz， Scheier, Fränkel，中山，保利，三上，奥山，佐山，湯 浅，稗田等の諸家の報告があり，多少見解の相違はある が，大体のところは一致しているようで，筆者の成績も 又これ等と汪ら゙近似している。

しかし以上の化简進行状態には著しい男女間の差異を 認め，こ机等に関して Fränkel は初期に扣いては男女 䦩の差異を認めないと言い，Chievitz，Scheier，保利， 三上，奥山，䄸田等は性別差を明らか認めている・即 
ち Chievitz, Scheier は舌状の化骨突起は男性に 特有 なもので, 中でる Scheier は化骨突起と前序部化栗核 は女性には全く認めないと述べ，Fränkel は女性に化 骨突起を1 例，前角部化骨核を多数認めている・本邦に おいて保利によると化骨突起は女性に稀であるが，皆無 ではなく（数例)，化骨核は女性に $15 \%$ に打いて証明さ れ，三上に上ると，化骨突起は女性に括いては 1 例放 めず，化監核は 50 代になつても 発生しない例が多く， 発生してる男性より概して掘いと言つて扣り，又稗田は

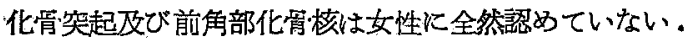

筆者の成績では男女間には明らかに差異を認め，男性 の場合は下縁汇沿うて，女性の場合は後縁に沿うて進 展するが，所謂舌状の化骨突起は殆んど男性にのみ認め られ，しか子男性では前角部及び、甲状切痕部等にも化 筲核を生じて進展するが，女性では前角部及び上甲状切

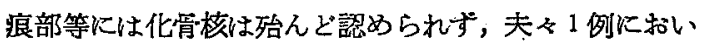
て男性同様の化骨突起及び上甲状切痕部に化骨核を認め たに過ざない。

2) 翰状軟骨

男女共に披裂関節面内側又は外側に化骨核を発現し， 外側のものは所謂亏側部及び板側下部に進及，甲状関節 面附近迄及び同時に披裂開節面内側のものと融合し，板 两側の化骨は中央部に和いて連絡する・男性では弓部上

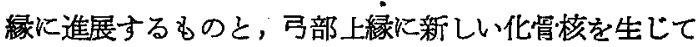
互いにこれ等が融合する場合とがあり，女性では弓部の 化霄沬全然認められなかつた。

輪状軟骨の化骨進行状態に就いて，従来は Fränkel， 中山，保利，三上，奥山，佐山，湯浅，稗田等の報告か あり，䇥者の成績もこれ等の成續と一致し，男女間の羑 異子又今迄の報告と同棈に殆んど性美を認めないが，女 性では弓部と板部の移行部には化骨を認めたが，弓部に は全然化骨を認めなかつた点がや」諸家の報告之異なつ ておりこれはいずれ弓部と板部の移行部より化骨が漸 次進展するものと思われ，注目に值する新所見である。

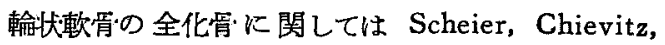
Fränkel 等はこれを認めているが，本邦においては湯 浅（生体に㧅いて）が 453 例中 3 例（男性 1，女性 2) を 経験したのみで，保利，三上，奥山，稗田等はこれを認 わておらず，籍者の成績にてる後者等と同じく全化骨をを 認めなからた・又輸状軟骨に物いては，気営に接する下

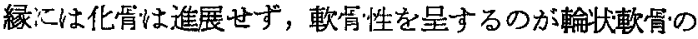
特徴とするところであるが，筆者の成績では1例(男性)

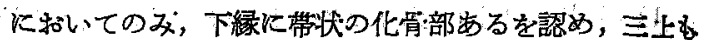
1 例 (性不明) 火乱いて同㥞の例を認めている。

3）披裂軟骨·

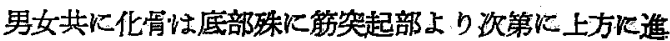
展し，男性では三角简の上界迄達するものがあるが，女 性では三角简の後側迄のものが多い。

披裂軟骨の化骨進行状態に就いて，従来はChievitz， Scheier, Fränkel，保利，三上，奥山，佐山，湯洩，稗 田等の報告があり，これ等るすべて底部に発現した化骨 核が漸㳄上方に進展すると言う筆者の成瀆と殆えど一致 するもので，男女間の差異も又これ等の報告と同椂都明 な性別的差異を認めない，唯男性では三角高の上舅迄進 展乙，女性の場合より化骨程度がや〉強い感があるが， 顕著ではない. 又全化骨に関しては，Scheier, Fränkel 等は認めているが，本邦においては未だかような報告は ないようであり，筆者の場合も文全化骨の例は認めなか つた.

2. 化骨出現率及び化骨出現部位のレ線学的，肉眼的 観察による比較

1) 化骨出現率

a) 上線学的観察

表 1 亿示すように，㜊頭軟管に和ける化骨現象の出現 率は一般に高率で，ᄂ䠌学的には 50 例の喉頭諸軟䯚中 の化骨を見たものは 48 例 $(96.0 \% \pm 2.77 \%)$ で，全然化 骨現象の痕跡も認めなかつたのは僅が2例（6.7\%土 $2.77 \%)$ に過ぎない.

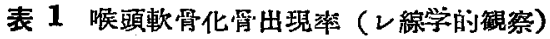

\begin{tabular}{|c|c|c|c|c|c|c|}
\hline Not生 & \multicolumn{2}{|r|}{ 송 } & \multicolumn{2}{|r|}{ 早 1} & \multicolumn{2}{|c|}{$5+9$} \\
\hline 理回 & 30 & $\%$ & 20 & $\%$ & 50 & $\%$ \\
\hline 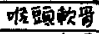 & 28 & $93,3 \pm 456$ & 20 & $100,0 \pm 0$ & 48 & $96,0 \pm 2 m 7$ \\
\hline 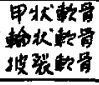 & $\begin{array}{l}28 \\
27 \\
24\end{array}$ & $\begin{array}{l}93.3 \pm 4.56 \\
40,0 * 5.45 \\
80.0 \div 5,17\end{array}$ & $\begin{array}{l}20 \\
20 \\
15\end{array}$ & $\begin{array}{l}100,0 \pm 0 \\
100.0 \pm 0 \\
75,0 \pm 9.69\end{array}$ & & $\begin{array}{l}960 \pm 777 \\
940 \pm 3.36 \\
78.0 \pm 586\end{array}$ \\
\hline
\end{tabular}

更にこれを喉頭各軟骨に就いて見ると，甲状軟骨の化 骨·出現分最も多く $96.0 \% \pm 2.77 \%$ （男性 $93.3 \% \pm 4.56 \%$ ， 女性 $100.0 \%$ ），次は輪状軟骨·の $94.0 \% \pm 3.36 \%$ （男性 $90.0 \% \pm 5.48 \%$ ，女性 $100.0 \%$ )，披裂軟穼の化骨出現山 最も少ないが $78.0 \% \pm 5.86 \%$ (男性 $80.0 \% \pm 5.17 \%$ ，女 性 $75.0 \%$ 土9.69\%） と半数以上が化骨現象を示し，女性

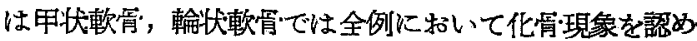
ている.

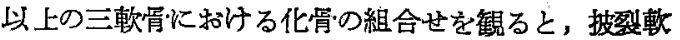

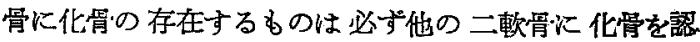

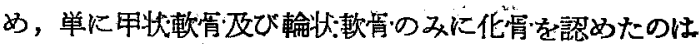


男性に和いて1例に過ぎなからた。

b) レ線学的観察之肉眼的観察の比較

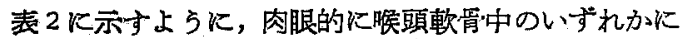
化骨を諗めたのは 48例 (96.0\%土2.77\%) で，更にこれ を喉頭各軟嚐就いて見ると，甲状軟骨が $96.0 \% \pm 2.77$ $\%$ (男性 $93.3 \% \pm 4.56 \%$ ，女性 $100.0 \%$ ） と最も多く， 次いで輪状軟骨の $92.0 \% \pm 2.83 \%$ (男性 90.0\%士5.48\%， 女性 $95.0 \% \pm 4.88 \%$ )，披裂軟骨 $58.0 \% \pm 6.98 \%$ (男性 $73.3 \% \pm 8.08 \%$ ，女性 $35.0 \% \pm 10.68 \%$ ） と最す少ない.

表 2 喉頭軟骨化骨出現率（肉腿的観察）

\begin{tabular}{|c|c|c|c|c|c|c|}
\hline \multirow{2}{*}{ 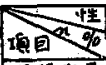 } & \multicolumn{2}{|r|}{$\boldsymbol{5}$} & \multicolumn{2}{|r|}{ 오 } & \multicolumn{2}{|c|}{$s+9$} \\
\hline & 30 & $\%$ & 20 & $\%$ & 50 & $\%$ \\
\hline 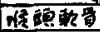 & 28 & $43.3 \pm 456$ & 20 & $100,0 \pm 0$ & 48 & $940 \pm 277$ \\
\hline 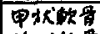 & 28 & $93.3 \pm 456$ & 20 & $1000 \pm 0$ & 48 & $96.0 \pm 2.77$ \\
\hline 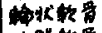 & 27 & $90.0 \pm 5.48$ & 19 & $95.0 \pm 4.88$ & $4 b$ & $92.0 \pm 3.53$ \\
\hline 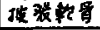 & 22 & 73. $3 \pm 8.05$ & 7 & $35.0 \leqslant 10.68$ & 29 & $580 \pm 0.98$ \\
\hline
\end{tabular}

即ち㬋頭軟骨の化骨出王睍率をレ線学的，因眼的に比較 すると，堠頭軟骨中いずれかに化骨を認めたるのは闭者 同率で全く差異を認めず，甲状軟骨，輪状軟骨（男性） に扣いても同様全く善異を認めない。

但しレ線学的に化骨現象を認めながら肉眼的にこれを

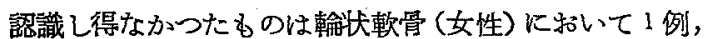
披裂軟骨に和いては男性 2 例，女性 8 例を数え，肉眼的 察のみに現われる出現率は男性 $73.3 \% \pm 8.08 \%$ ，女性 $35.0 \% \pm 10.68 \%$ と女性に杂いてその美が強い. 又圤上 の三軟骨に持ける化骨の組合せをみると，レ線学的には この中 1 例において披裂軟骨に化骨を想めながら輪状軟 骨には諗めなかつた・

2) 化骨出現部位

i. 甲状軟管

化骨の出現部位を後縁，下角，下甲状結節，上盾，上 縁，上甲状切痕部，前角の各部に分けて観察した。

a) V楾学的察

表 3 甲状軟尔 (レ線学的䂓察)

\begin{tabular}{|c|c|c|c|c|c|c|}
\hline \multirow{2}{*}{\multicolumn{2}{|c|}{ pin }} & 否 & \multicolumn{2}{|r|}{9} & \multicolumn{2}{|c|}{$5+9$} \\
\hline & & $\%$ & 20 & $\%$ & 50 & $\mathscr{E}$ \\
\hline$y=\frac{1}{x_{2}}$ & 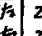 & $96.7+3.26$ & 20 & & 49 & $980 \pm 192$ \\
\hline & 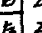 & $96.7+326$ & $\begin{array}{l}20 \\
19\end{array}$ & $\begin{array}{l}100,0 \pm 0 \\
95,0 \pm 478\end{array}$ & $\begin{array}{l}47 \\
45\end{array}$ & $\begin{array}{l}98.0 \pm 19 \delta \\
90.0 \pm 424\end{array}$ \\
\hline 下市 & 6 & $2^{3} 3 \pm 451$ & 19 & $950 \pm 4.8$ & 44 & $88.0 \pm 459$ \\
\hline$F$ Fol $x=5$ & $\%$ & $43.3 \pm 4,56$ & 17 & $55.0 \pm 799$ & 45 & $90.0 \pm 4.24$ \\
\hline Thanever & $E$ & $43.3 \pm 456$ & 7 & $x 50 \pm 299$ & 45 & $93.0 \pm 4.24$ \\
\hline 上而 & 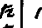 & $53.3=9.10$ & it & $75.0 \pm 9.69$ & 41 & $820 \times 543$ \\
\hline & 5 & $53.3 \pm 9.10$ & 14 & $70.0 \pm 10.25$ & 40 & $80.0 \pm 4.66$ \\
\hline & $\hbar$ & $36.7 \pm 7 \times 20$ & I & $5.0 \pm 478$ & 12 & $240 \pm 6.04$ \\
\hline & 古 & $30.0 \pm 2.34$ & 1 & $10 \pm 4 \pi 5$ & 10 & $200 \pm 5.66$ \\
\hline & F & $5 x 3 \pm 9.10$ & ' & $5.0 \pm 488$ & 17 & $340 \pm 670$ \\
\hline & & $50.0=9.13$ & 1 & $\begin{array}{l}50 \pm 4 \pi 8 \\
5,0=488\end{array}$ & $\begin{array}{l}16 \\
21\end{array}$ & $\begin{array}{l}320 \pm 6.60 \\
420 \pm 418\end{array}$ \\
\hline & & $667 \pm 8.60$ & 2 & & & \\
\hline
\end{tabular}

表 3 に示すように，後縁，下甲状結節及び下角に最も 多く，上角これに次き，更に前角部，上甲状切痕部の䐓 で上緑に出現するるのが最む少ない。

側別：男女共左右相互間には殆んど善翼を認めない。 性別：表 4, 図1に示すよらに, 男性にては後緑,下゙ 角，上角に抏いて女性よりゃ〉少なく，男性では後縁， 下甲状結節，下角，前角，上居，上甲状切㿉部，上緣の 順であるが，女性では後緑，下角，下甲状結節，上角の 順に多く，特に前角，上甲状切痕部，上縁においては 各た1例宛認められたのみである。

表 4 甲状軟骨 (レ線学的锶祭)

\begin{tabular}{|c|c|c|c|}
\hline & 5 & 후 & $\Delta+9$ \\
\hline & $\%$ & $\%$ & $\%$ \\
\hline 猪脿 & $907 \pm 2.31$ & $1000 * 0$ & $980 \pm 1160$ \\
\hline 下 & $25.0 \pm 4.62$ & $95.0 \pm 3,45$ & $89.0 \pm 3 / 3$ \\
\hline 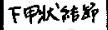 & $9,3,3 \pm 3,23$ & $75.0 \pm 5.65$ & $90.0 \pm 300$ \\
\hline 上. & $53.3 * 6.44$ & $72.5 \pm 7.06$ & $810 \pm 3,92$ \\
\hline 上縁 & $33.3 \pm 6.08$ & $5.0 \pm 3.45$ & $22.0 \pm 4.15$ \\
\hline 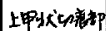 & $51.8 \pm 0.45$ & $5,0 \pm 3.45$ & $33.0 \pm 470$ \\
\hline 的 1 & $66.7 \pm 6.08$ & $5.0 \pm 345$ & 42004494 \\
\hline
\end{tabular}

图 1

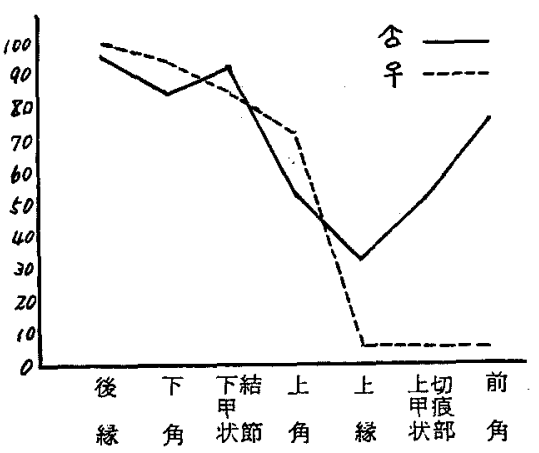

年令 別:

(21 才〜30才)；化骨状涚は図 2 に示す上らに，男女 图 2

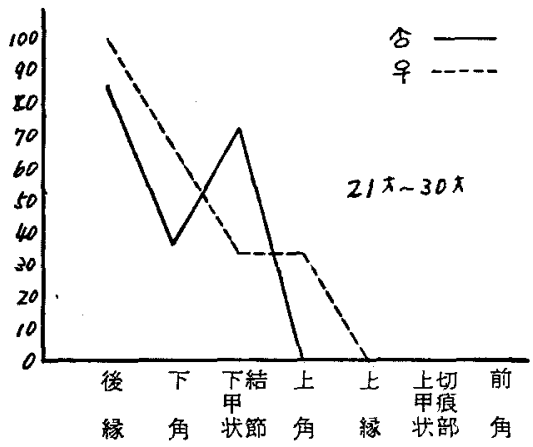



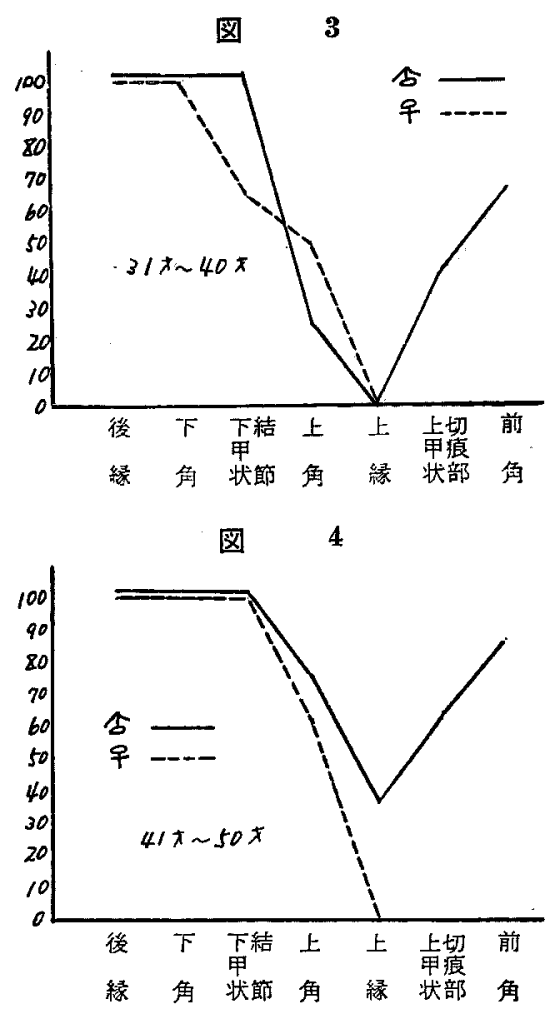

図 5

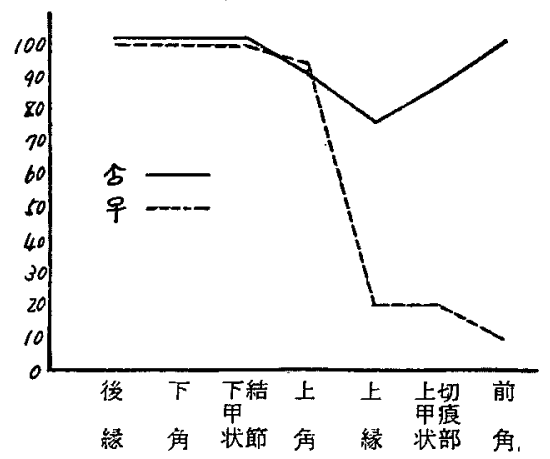

共後緣に多く，男性では下甲状結節，下角の順である が，女性では下角，下角状結節の順で，而も後縁，下角 に扎いて女性は男性より化骨の出現多く，既に女性では 上角に化骨の出現を見る・即ちこの年代では女性の方が 化骨出現がや>男上り堙つている。

(31 才〜40才)；図3に示寸上5に，男女期後緣，下 角には $100 \%$ に化骨を䛱め，又男性では下甲状結節にる 100\%に諗めるが，女性では未だすべての部位には認め ず，化骨の出現のない部位は男性では上緣のみである
が，女性では前角，上甲状甽痕部，上縁の3ヶ所に及灾 でいる。

(14才〜50才)：図4に示すようにこの年代になる と，男性はすべての部位に化督を認めるが，女性ではな 招前角，上甲状切痕部，上線等に和ける出現はない。

(51 才以上)：この年令階級になると，男女共に化骨 は各部位に認められるようになるが，出現頻度の低い上 縁，上甲状切痕部，前角部等に括いては男性に頻度高 く，女性に頻度低いのが目立つてくる・

以上より21才〜30才に和いてのみ，女性は男性より や\高率の傾向があり，他はすべて男性が高率を保って いる・即ち甲状軟胥·の化胥出現は女性が男性よりるや」 早期である.

b) ᄂ線学的権察之肉眼的㩁察の比較

表 3，5，図6に示すように，レ線学的，因眼的にす観 察誤差は少なく，両者間には大差はない，而して後縁， 下甲状結節及び下角に高率で，上角，上甲状切痕部，前 角，上縁等に低率である・見掛上は全般を通じて参眼的 観察の方がや子㸓つている.

表 5 甲状軟督 (肉眼的観察)

\begin{tabular}{|c|c|c|c|c|c|c|c|}
\hline \multirow{2}{*}{\multicolumn{2}{|c|}{ 部位 $x \frac{4 \%}{\%}$}} & \multicolumn{2}{|r|}{ 송 } & \multicolumn{2}{|r|}{9} & \multicolumn{2}{|c|}{$5+8$} \\
\hline & & 30 & $\%$ & 20 & $\%$ & 50 & $\%$ \\
\hline \multirow{2}{*}{ 猜新 } & $\sqrt{1 / 2}$ & 24 & $80.0 \pm 730$ & 19 & $95,0 \pm 6.5 x$ & 43 & $860 \pm 491$ \\
\hline & t & 23 & $76.7 \pm 772$ & 19 & $950 \pm 4.88$ & 42 & $240=519$ \\
\hline \multirow{2}{*}{ 下角 } & $\sqrt{2}$ & 24 & $80.0 \pm 730$ & 19 & $95.0 \pm 488$ & 43 & $26,0 \pm 491$ \\
\hline & 5 & 24 & $80.0=7.30$ & 19 & $95.0 \pm 4.88$ & 43 & $26,0 \pm 4.91$ \\
\hline \multirow{2}{*}{ 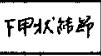 } & $1 / 2$ & 28 & $933=456$ & 16 & $80,0 \pm 894$ & 44 & $880 \pm 459$ \\
\hline & 右 & 28 & $93.3 \pm 456$ & 17 & $25,0 \pm 799$ & 45 & $90.0 \pm 424$ \\
\hline \multirow{2}{*}{ 上而 } & $\sqrt{2}$ & 15 & $50.0 \pm 9.13$ & 11 & $55.0 \pm 11.111$ & $2 b$ & $520 \pm 706$ \\
\hline & 占 & 16 & $53.3=9.10$ &,$r$ & $55,0 \pm 11.11$ & 27 & $540 \pm 705$ \\
\hline \multirow{2}{*}{ 上 $y^{2}$} & $\sqrt{2}$ & 9 & $30.0 \leq x 34$ & 1 & $50 \pm 458$ & 10 & $20.0 \pm 5.66$ \\
\hline & to & 9 & $30.0 \times 834$ & 1 & $5.0 \pm 4 \pi x$ & 10 & $20.0=5.66$ \\
\hline \multirow{3}{*}{ 上甲将的表部 } & $F_{2}$ & 13 & $43.3 \times 9.04$ & 0 & & 13 & $260 \pm 0.21$ \\
\hline & & 13 & $(4.3]=9.04$ & 0 & & 13 & $260 \pm 621$ \\
\hline & & 18 & $60.0 \div 2.84$ & 0 & & 18 & $36.0 \pm 6.99$ \\
\hline
\end{tabular}

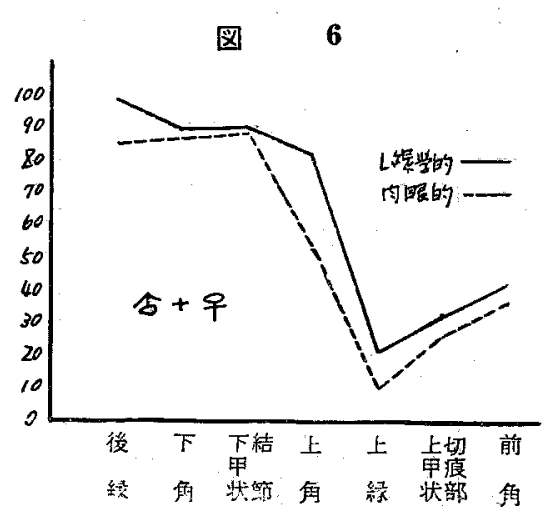

側別：男女共左右相互間には殆えど差異を認めない 
のは闭鹳察共全く一致する。

表 6 甲状軟䅐 (肉眼的微察)

\begin{tabular}{|c|c|c|c|}
\hline & 5 & क & $5+4$ \\
\hline & $\%$ & $\%$ & $\%$ \\
\hline & $72,3+532$ & $95,0 \pm 245$ & $85,0 \pm 2,58$ \\
\hline & $80.0 \pm 5 / 7$ & $95,0<3.45$ & $26,0 \pm 3.46$ \\
\hline 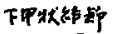 & $93.3+223$ & $22.5 \times 601$ & $76.0 \pm 2 / 3$ \\
\hline 土哩。 & $51.7 \mathrm{kak5}$ & $55.0 \div 787$ & $53.0 \times 4.99$ \\
\hline \pm & $30.0 \pm 592$ & $510+345$ & $10.0 \pm 3.00$ \\
\hline 上甲狂加痕部 & $4.23=640$ & & $26,0 \pm 43 \pi$ \\
\hline 藏 & $60.0 \pm 433$ & & $36,0 \div 480$ \\
\hline
\end{tabular}

図 7

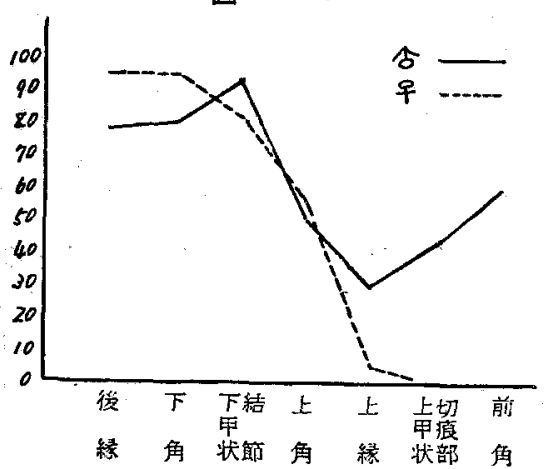

性別：表 4，6，図 1，7 に示すように，男女間のレ線 学的，肉眼的化胥出現傾向は多少の差はあるが殆んど一

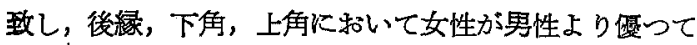
いるのも两観察相一致し，女性では上甲状切痕部，前角 において肉眼的に全然㒛める事ができなかつた。

年 令 別:

男件；図8〜11に示才ように，21才〜30才の後縁に おいてレ線学的に $85.7 \%$ 出現するのに反し，肉眼的に は $7.1 \%$ と著しい差異を諗め，又 31 才〜 40 才の上甲状

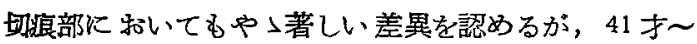
50 才，51 才以上に颃いては殆んど差異を認めない。

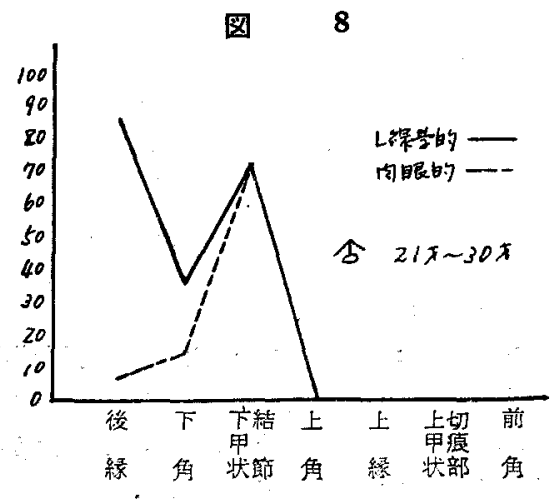

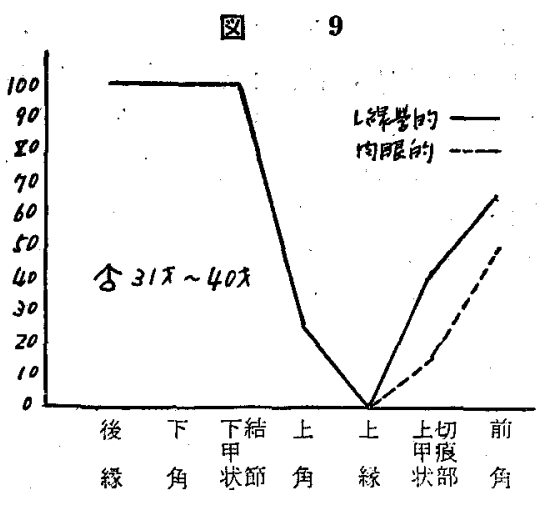
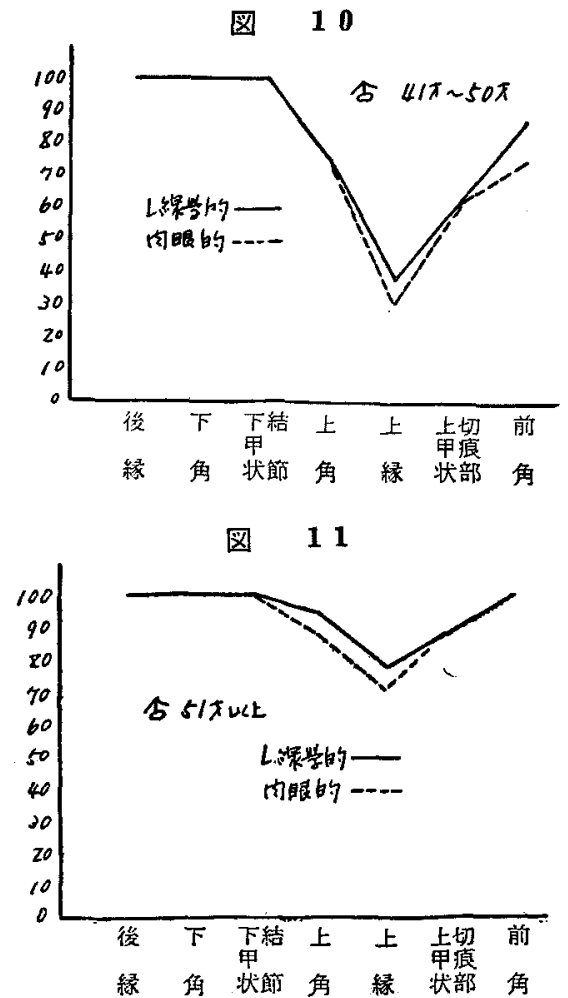

以上の事は前述の甲状軟胥の化骨進行状態でる解るよ らに，男性では最初化骨核は下角基部及び下角基部後緑 部に発現し，下縁及び後縁に同時に下角にも進展し，下 縁に沿らて前進するるのと，一方後縁に沿うて上䄯する あのとがあり，21 才〜30才の年代では下縁に沿らで前 進する時期が，後緑を上昇する時其に路でて早期である 事を物語つている。

㕛次の31 才〜40才の年代では後縁には100\%に出現 しレ線学的と肉眼的には全く一致し，即ちこの年代には 
主に後縁を上昇して化骨は進展するすのである・

一方下縁を前進し，下甲状結節を越えて進行したもの は，前角，上甲状切痕部に発現した化骨核と融合して進 展するため，肉眼的にはこの年代に前角，上甲状切痕部

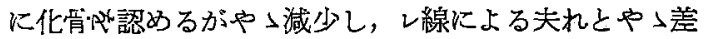
異を示している・即ら前角，上甲状切痕部は主に次の年 代（41 才〜50才）に化雷は進展するるのである・

图 12

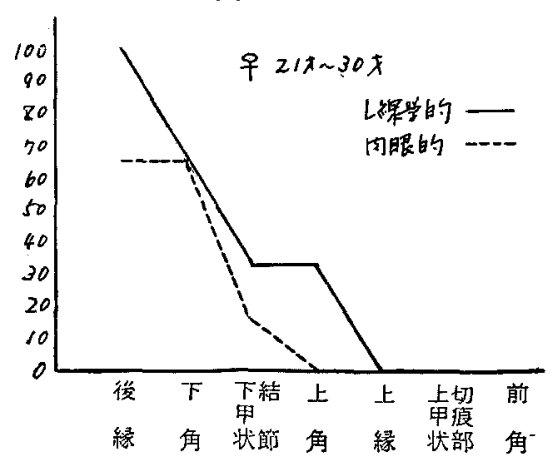

圈 13

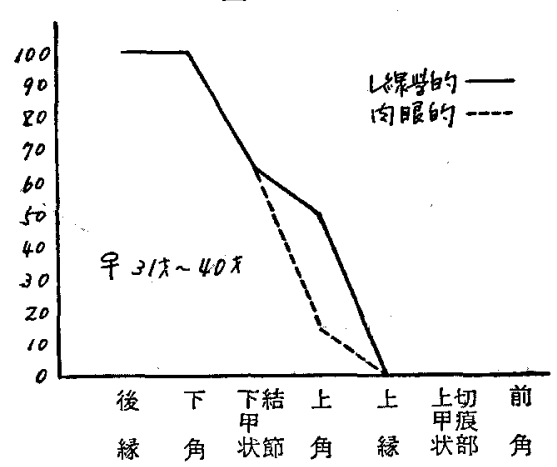

女性；図12，13に示すように，21才〜30才に打 る後縁ではレ線学的に100\%，肉眼的には66.7\%に化骨" を認め，文下甲状結節では両者の差が後緑におけるよう な差を認めないこれは前述の女性の甲状軟骨進行状態 より解るように，化骨は下縁に沿らて前進するより先つ 後縁を上昇し，や小遅れて下緑を前進するものであり， 後縁のものは上角に及び漸次板側部を中央へ前進し，所 謂女性特有の進行状態を以て 化骨すするので，41 才上 上ではレ線学的観察と肉腿的観察とは全く相一致する。

ii. 輪状軟䎡.

化骨の出現部位を披裂関節面外側，披裂関節面内側， 甲状関節面附近，板部，弓部に分けて観察した・

\section{a) V線学的観察}

輪状軟骨にては化骨は表7に示すように，披裂関節面 の外側に出現するものが最も多く，披裂関節面内側及び 甲状閣節面附近がこれに次き，板部において次第に減少 し弓部におけるものが最も少数である・

奏 7 輪状軟霄 ( $($ 線学的锖察)

\begin{tabular}{|c|c|c|c|c|c|c|c|}
\hline \multirow{2}{*}{\multicolumn{2}{|c|}{ 部位舟 $\%$}} & \multicolumn{2}{|r|}{ 否 } & \multicolumn{2}{|r|}{9} & \multicolumn{2}{|r|}{$5+q$} \\
\hline & & 30 & $\%$ & 20 & 76 & 50 & 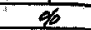 \\
\hline 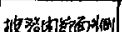 & $t$ & 27 & $90.0 \pm 54 \pi$ & 20 & $100,0 \pm 0$ & 47 & $040 \div 2.36$ \\
\hline & 5 & 27 & $90.0 \pm 5.48$ & zo & $100,0 \neq 0$ & 47 & $940=236$ \\
\hline 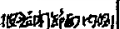 & $\sqrt{2}$ & 24 & $200 \pm 730$ & 19 & $95.0 \pm 4228$ & 43 & $830+491$ \\
\hline & 河 & 23 & $767 \times 772$ & 19 & $95,0 \pm 4.82$ & 42 & $840 \times 5.19$ \\
\hline 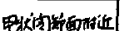 & $\mid \sqrt[3]{\pi}$ & 19 & $61.3 \pm 820$ & 11 & $5(10 \times 1+14)$ & 30 & 60.04673 \\
\hline & ta & 20 & $66.7 \pm 2.60$ & 12 & $60,0<1045$ & 32 & $640 \times 6.79$ \\
\hline 板辂 & $\sqrt{\mathbf{2}}$ & 11 & $32.3 \pm 260$ & 5 & $25,0=869$ & 16 & $320 \times 6,60$ \\
\hline & & 11 & $32.3 \pm x 60$ & 5 & $25,0=869$ & 16 & $320=460$ \\
\hline & $\begin{array}{l}12 \\
6 \\
b\end{array}$ & 12 & $\begin{array}{l}40.0 \pm 7.94 \\
333 \pm 2.60\end{array}$ & 0 & & & $\begin{array}{l}240 \times 604 \\
22.0 \pm 5.26\end{array}$ \\
\hline
\end{tabular}

側別：男女共左右相互間には殆んど差異を認めない。 性利：表8，図14亿示すよ5に，男性性裂関節面 外側及び内側に打いて女性より荌つており，甲状閣節面 附近，弓部，板部に扎いて男性が優り，特に弓部に和い ては女性では 1 例も認められなからた。

表 8 輸状軟留 (レ線学的観䋈)

\begin{tabular}{|c|c|c|c|}
\hline 4 & 艿 & 9 & S5+ \\
\hline 部位 & $\%$ & $\%$ & $\%$ \\
\hline 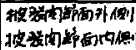 & $\begin{array}{l}90.0 \div 387 \\
78.3 \pm 532\end{array}$ & $\begin{array}{l}100.0 \pm 0 \\
95.0 \pm 3.45\end{array}$ & \\
\hline 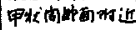 & $65.0 \pm 6.16$ & $57.5 \pm 752$ & $620 \pm 416$ \\
\hline 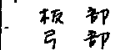 & $\begin{array}{l}33.3 \pm 4.08 \\
323 \pm 6.28\end{array}$ & $250 \times 685$ & $\begin{array}{l}32.0 \pm 467 \\
333 \pm 470\end{array}$ \\
\hline
\end{tabular}

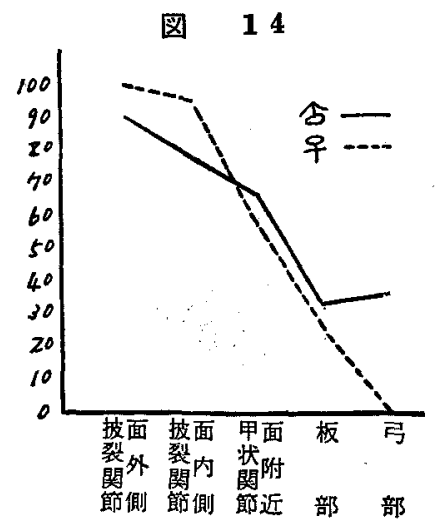

年命 別:

（21 才〜30才）；図15に゙示すように，男女共披裂関 節面外側，内側，甲状関節面附近の順序に出現するが， いずれる女性は男性より化骨の出現多く，既に女性では 披裂関節面外側に $100 \%$ に諗められる。 


\section{図}

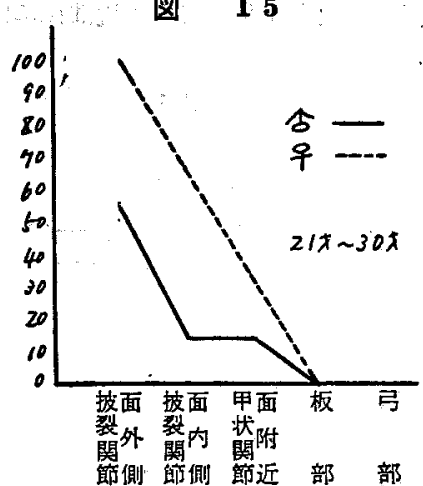

(31 才 40才)；図16に示寸ように，男性では披裂 関節面外側に $100 \%$ ，内側にも殆んど出現し，弓部尤び 板部には出現を見ない.女性では披裂関節面外・内側に は $100 \%$ に出現, 男性の化骨出現部位と比較し殆んど一 し票ている。
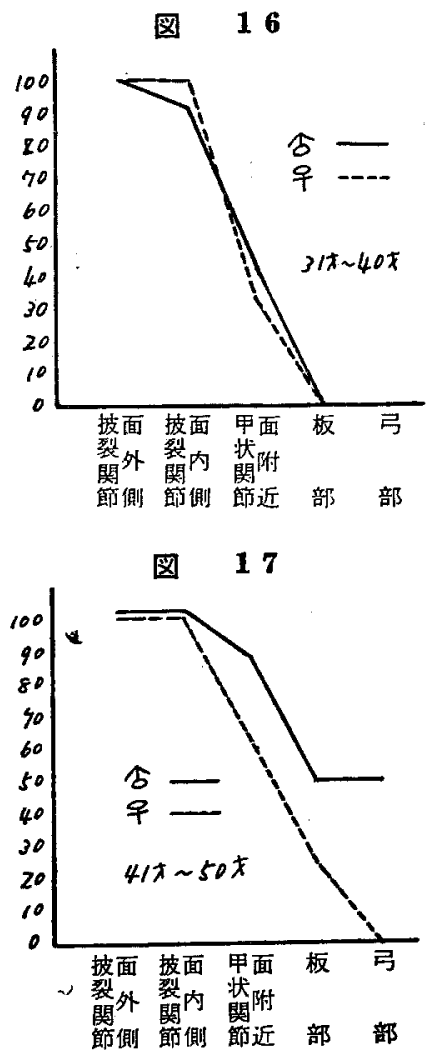

(41 才〜50才); 図 17 亿示すように，男女共披裂関 節面外・内側に $100 \%$ に認め, この年代には男性ではす
图 $\quad 18$

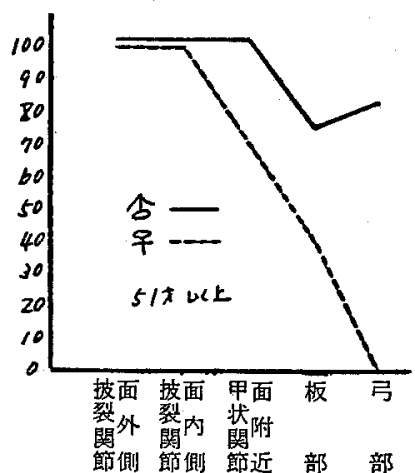

べての化骨部位に出現し， 弓部及び板部にも50\%認め。 られるが，女性では板部にのみ出現し弓部には未だ出現 しない.

(51 才以上)：図18に示すように，前年代より化骨の. 出現は男女共多くなつて括り，勿論男性が女性上り優っ ているが，女性では弓部には I 例も認めなかつた。

上上より 21 才 30才に执いてのみ女性は男性より優 り，31 お 40 才では殆んど一致し，41 才以上では男性 は女性より優つている.

即ち輪状軟骨の化骨出現の時期は女性に扎いて男性よ りも早斯であり，男女共前述の化骨進行状態と全く同様 の出現部位を示し，化骨出現部位より見た化骨進行状態 は年代により程度の差はあるが，甲状軟骨に話けるよう な著しい差異を認めない。

b) ᄂ線学的観察之肉眼的観察の比輅

表7，9，図19に示すように，化骨はレ線学的，肉眼 的にも披裂関節面外・内側に出現するものが多く，前者 では披裂関節面外側, 内側，申状関節面附近，弓部，板 部の順であるが，後者では披裂関節面内側，次は僅かに 㸓つて披裂関節面外側，甲状関節面附近，板部，弓部の 順で，レ線学的観察における化骨出現部位の方がや小優 っている.

表 9 愉状軟骨（约腿们微察）

\begin{tabular}{|c|c|c|c|c|c|c|c|}
\hline \multirow{2}{*}{\multicolumn{2}{|c|}{ 部位 ${ }^{n} \%$}} & \multicolumn{2}{|r|}{ 古 } & \multicolumn{2}{|r|}{9} & \multicolumn{2}{|c|}{ 占+干 } \\
\hline & & 30 & $\%$ & 20 & $\%$ & 50 & $\%$ \\
\hline 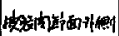 & {$\left[\begin{array}{c}t_{2} \\
5 \\
5\end{array}\right]$} & 26 & $26,7+6,20$ & 16 & $80.0+294$ & 42 & $240 \pm 519$ \\
\hline & 16 & 25 & $23.3 \pm 6.21$ & 16 & 20.058 .44 & $k 1$ & $820 \pm 5.4 \mathrm{~J}$ \\
\hline & $\sqrt{2}$ & 24 & $20.0 \pm 736$ & 19 & $9510 \leq 48 \pi$ & 43 & 2400441 \\
\hline & t & 23 & $747 \div 772$ & 19 & $95,0 \pm 488$ & 42 & $240 \pm 5119$ \\
\hline 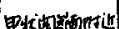 & $\sqrt{2}$ & 19 & $63.3 \pm 280$ & 4 & $20,0 \pm 294$ & 23 & $400=2.55$ \\
\hline & $\hbar$ & 20 & $66,7 \pm 8.60$ & 4 & $20.0=2.94$ & 24 & $480 \pm 706$ \\
\hline 板 & $\sqrt{2}$ & $" 1$ & $53.3 \times x .60$ & 4 & $200 \div 894$ & 15 & $300 \pm 648$ \\
\hline & 5 & 11 & $93.3 \pm 260$ & 4 & $20.0 \times 294$ & 15 & $30.0 \neq 4.48$ \\
\hline 弓 部 & $\left|\begin{array}{l}\mathbf{2} \\
5\end{array}\right|$ & $\begin{array}{l}12 \\
11\end{array}$ & $\begin{array}{l}400 \pm 8.94 \\
313 \times 8.62\end{array}$ & $\begin{array}{l}0 \\
0\end{array}$ & & $\begin{array}{l}12 \\
11\end{array}$ & $\begin{array}{l}240 \pm 6.04 \\
22.0 \pm 0.26\end{array}$ \\
\hline
\end{tabular}




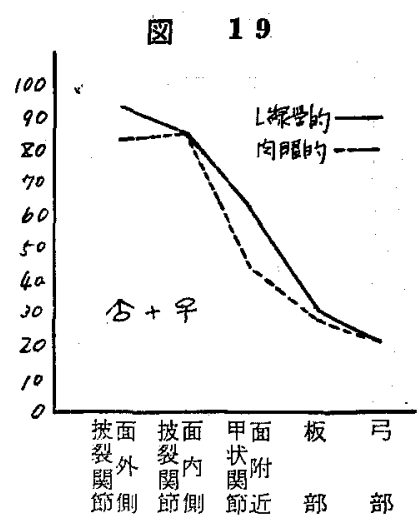

側別：両者共男女左右相互間には殆んど 差異を認め 756

性別；表 8，10k示すよちに，男女間のレ線学的， 肉眼的化骨出現傾向は殆んど一致し，肉眼的観察では披 裂関節面内側に扣いて女性が優つている以外は披裂関節 面内側に捛いて女性が優つている以外性裂篹節面外側

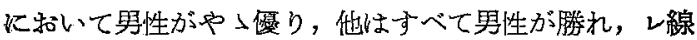
学的観察同様户部に和いて女性では 1 例子諰められなか つた.

表 10 輸状軟胥（肉浱的钼察）

\begin{tabular}{|c|c|c|c|}
\hline & 5 & $\%$ & $5+4$ \\
\hline 部位 & $\%$ & 96 & 96 \\
\hline 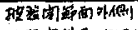 & $85,0 \neq 4$ & $80.0 \pm 4.33$ & \\
\hline 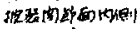 & $783=$ & $950 \times 3.45$ & $250 \pm+59$ \\
\hline 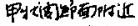 & $65.0 \pm$ & $20,0 \pm 633$ & $470 \div 499$ \\
\hline 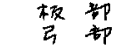 & $\begin{array}{l}33.3+608 \\
3 \times 3=0.28\end{array}$ & $200+633$ & $\begin{array}{l}30.0 \pm 458 \\
23.0=421\end{array}$ \\
\hline
\end{tabular}

図 20

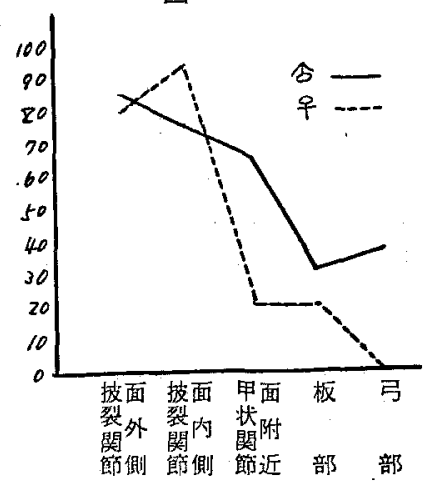

年 令 刮 :

男性；図 21 k示すよ にに，21才〜30才の披裂関節 面外側に和いてレ線学的に $57.1 \%$ 現れ，因眼的には 35.7\%とや」舟つているが，その他の部位では両者全 く一致し，31 才〜40才，41才〜50才，51 才以上でも
画者は進展範囲の大小はあつても出現部位には全く差異 を諗めない。

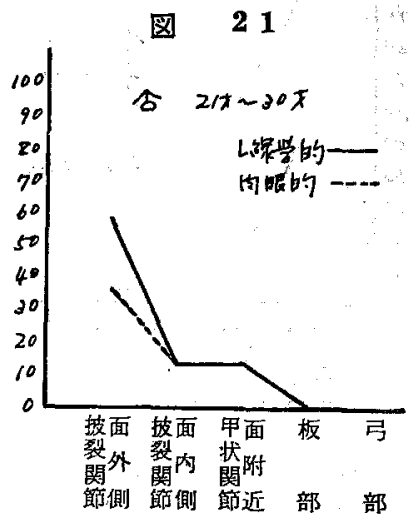

女性；22２5に示すよらに，21才〜30才では披裂関 節内側はレ線学的，肉眼的に全く一致し，乙か子前者て は披裂関節外側，内側，甲状関節面附近の順に 3 r所に 出現するが，後者では披裂関節面外側亡内側訫認められ るのみで，外側に和ける出現は前者の夫れより1/2に減 少している・31才〜40才では肉腿的に披裂閣節面外側 において未だ为り，甲状閔節面附近には1例正認めな w。

41 才〜50才になると，肉眼的に甲状関節面附近，板 部に認めるようになり，披縁節面外側及び甲状関即面 附近に括いては未だ劣り，51 才以上では甲状閔節面附 近に和りる化骨出現が肉眼的に㘯つているが，他性全く 一致するか殆えど差異を認めない。

図 22

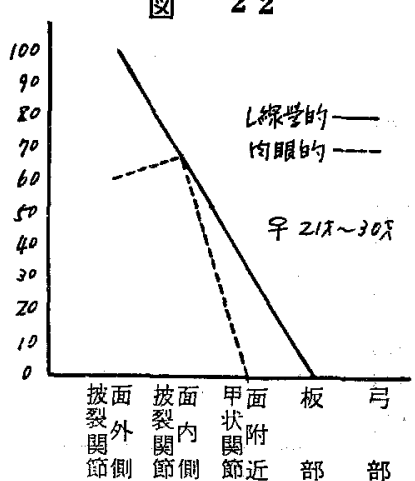

即ら男性では 21 才〜30才の 披裂関節面外側において 因眼的観察がや」物つている以外は，上線学的及び肉腿 的観察性者者全く一致し；女性ではレ線学的には披裂関 節面外側に最初から $100 \%$ に出現し最子多く認められる 

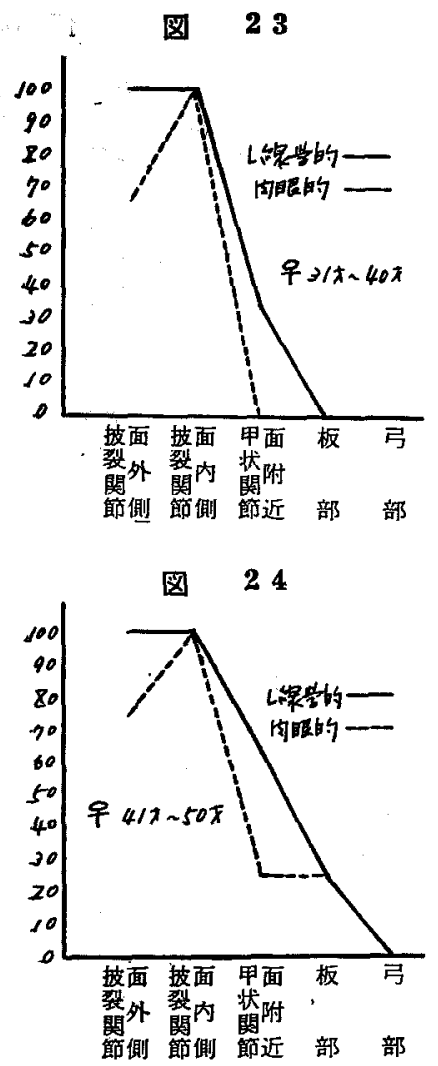

图 25

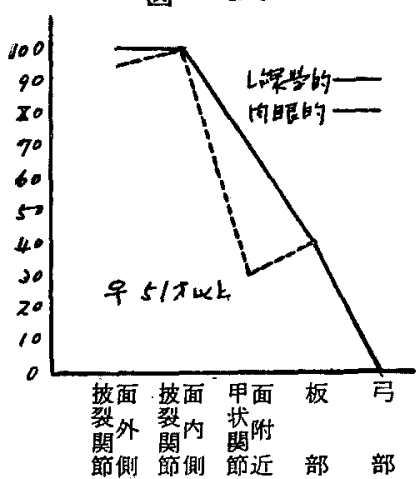

が，因眼的には披裂閏節面内側に最子多く認められ，乙 かむ各年代を通じてレ線学的と全く一致し，板部は 41 才〜50才より出現しレ線学的にも肉眼的にも全く一致 するが，他の部位ではレ線による敬合が見脚上勝れてい る.

このよらに輪状軟骨に招いても甲状軟骨と同様にレ線 学的観察の方が肉眼的観察よりや今優つて括り, 肉眼的

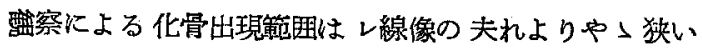
が軟骨を透かして見るとレ線学牨観察による化骨出現筑 因と殆んど一致しており，これは男泩に抌いてその度が 强い(図 17, 18 参照)。

iii. 披裂軟骨

化骨の出現部位を底部及び中央部に分けて筧察した。

a) レ線学的観察

䒧11に示すように，化骨は底部に出現するものが最 も多く，中央部これに次ぎ，尖端部には遂に認めなかつ た。

表 11 披裂軟霄 (

\begin{tabular}{|c|c|c|c|c|c|c|c|}
\hline \multirow{2}{*}{\multicolumn{2}{|c|}{ 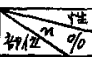 }} & \multicolumn{2}{|r|}{5} & \multicolumn{2}{|r|}{ 우 } & \multicolumn{2}{|c|}{$6+9$} \\
\hline & & 30 & $\%$ & 20 & $\%$ & 50 & $\%$ \\
\hline 唐钟 & $\begin{array}{l}\frac{1}{2} \\
\frac{1}{6}\end{array}$ & 23 & & 15 & $75.0 \pm 9.69$ & 38 & $76.0 \pm 6.08$ \\
\hline 中央却 & $\mid \frac{1}{2}$ & $\begin{array}{l}22 \\
16 \\
16\end{array}$ & $\begin{array}{l}7.3 \pm 808 \\
5.3 \pm 9.10 \\
533+9.10\end{array}$ & $\begin{array}{r}15 \\
6\end{array}$ & $\begin{array}{l}75,0 \pm 269 \\
300 \pm 1425\end{array}$ & $\begin{array}{l}37 \\
22 \\
73\end{array}$ & $\begin{array}{l}740 \pm 921 \\
440.702\end{array}$ \\
\hline
\end{tabular}

側別：男女共左右相互間には殆んど差異を認めない。 性別：表 12, 図 26 に示すよ 5 に，男女共底部に翟め たものが $75.0 \%$ と全く一致し，中央部において男性 $53.3 \%$ ，女性 $32.5 \%$ 之男性の方が多い。

表 12 披裂軟简 (レ線学䶺钼察)

\begin{tabular}{|c|c|c|c|}
\hline$\underbrace{\mid \Psi}$ & 5 & 우 & 否+早 \\
\hline 部位象 & $\%$ & $\%$ & 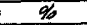 \\
\hline 离事 & $\begin{array}{l}75,0 \pm 5,60 \\
53,3=6,44\end{array}$ & $\begin{array}{l}35.0 \div 6.76 \\
32.5+740\end{array}$ & $\begin{array}{l}75.0+4.34 \\
45.0 \pm 4.8\end{array}$ \\
\hline
\end{tabular}

図 26

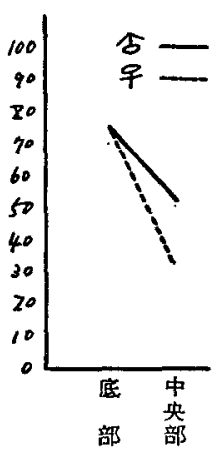

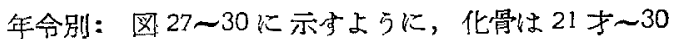
才では男女共底部にのみ出現し，女性の方の出現が多 い. 31 才〜40才では中央部にも出現し，底部ではや」 男性の旗つている，41 お〜50才では底部，中央部 共にや」男性が嘎り，51 才上上では男性は 100\%に底 部，中央部に認められるが，女性は中央部には $40.0 \%$ と1/2 以下である。 


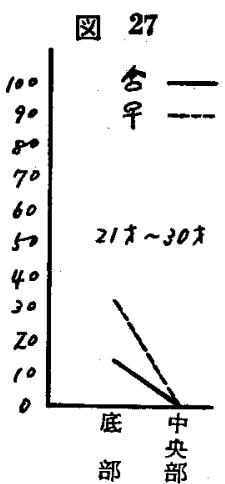

国 29

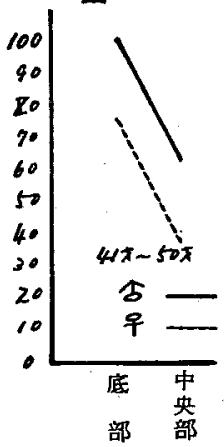

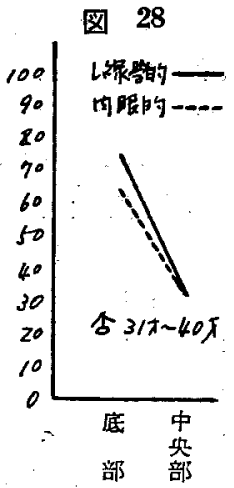

圈 30

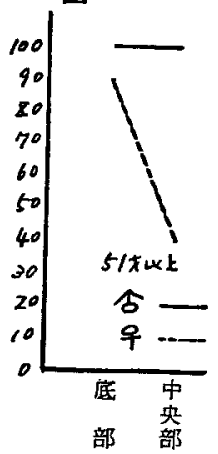

即ら化骨進行状態で述べたように，化骨の出現は女性 に和いてゃ〉早く，その後男性の方の進行が早くしかも 広範囲に進展する。

b) レ線学的観察と肉腿的観察の比較

表11，13，図31に示可与5に，上線学的，肉眼的に も底部に出現するものが多く，中央部では肉眼的には左 側 4 例，右側 5 例に認められたのみである.

表 13 披裂軟霄 (闪哏的知祭)

\begin{tabular}{|c|c|c|c|c|c|c|c|}
\hline \multirow{2}{*}{\multicolumn{2}{|c|}{ 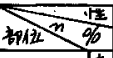 }} & \multicolumn{2}{|r|}{5} & \multicolumn{2}{|r|}{ 우 } & \multicolumn{2}{|c|}{$5+9$} \\
\hline & & 30 & $\%$ & 20 & $\%$ & 50 & \% \\
\hline 散 & $\mid \begin{array}{l}\hbar_{2} \\
\hbar_{1}\end{array}$ & $\begin{array}{l}20 \\
20\end{array}$ & & $\frac{9}{8}$ & & $\begin{array}{l}29 \\
28\end{array}$ & \\
\hline 中央蚛 & $\begin{array}{l}\boldsymbol{F} \\
\hbar \hbar\end{array}$ & $\begin{array}{l}12 \\
12\end{array}$ & $\begin{array}{l}400 \pm 894 \\
400 \pm x 94\end{array}$ & 4 & & 16 & $\begin{array}{l}320 \pm 460 \\
32.0 \pm 460\end{array}$ \\
\hline
\end{tabular}

表 14 披裂軟骨（肉腿的観察）

\begin{tabular}{|c|c|c|c|}
\hline$\sqrt{ }+4$ & 客 & 8 & s+a \\
\hline+1 & $\%$ & $\%$ & \% \\
\hline 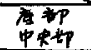 & $\begin{array}{l}647 \pm 608 \\
4 a 0 \pm 433\end{array}$ & $\begin{array}{l}425 \pm \pi 22 \\
20.0 \pm 433\end{array}$ & $\begin{array}{l}570 \pm 4495 \\
320 \pm 467\end{array}$ \\
\hline
\end{tabular}

側別：両者男女共左右相互間には殆んど差異を認め ない

性別：表 12，14，図 26，32 に示与上5K，上楾学的に は底部に括いて男女一致し，中央部に括いては男性が㑭

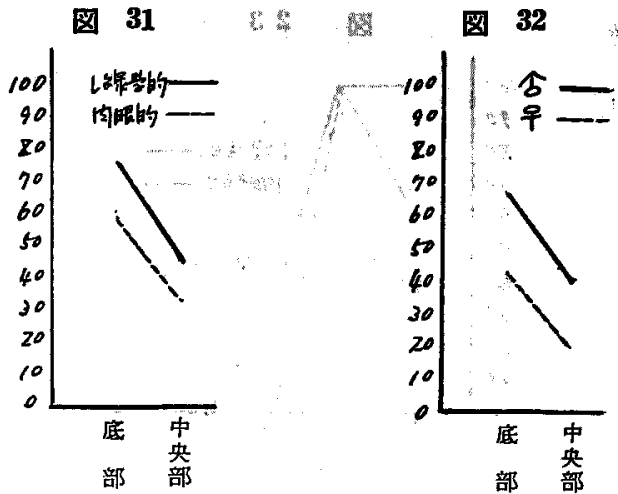

つているが，肉眼的には底部，中央部共に男性が傮つて いる。

年 令 別:

男性；図 33〜35に示すように，21 才〜30才では肉 眼的には全然諗められず，31 才〜40才，41 才〜50才て は一部一致するか又は僅差を示し，51 才以上では底部 においては両者共 $100 \%$ に出現し，中央部において肉眼 的が㸓つている。
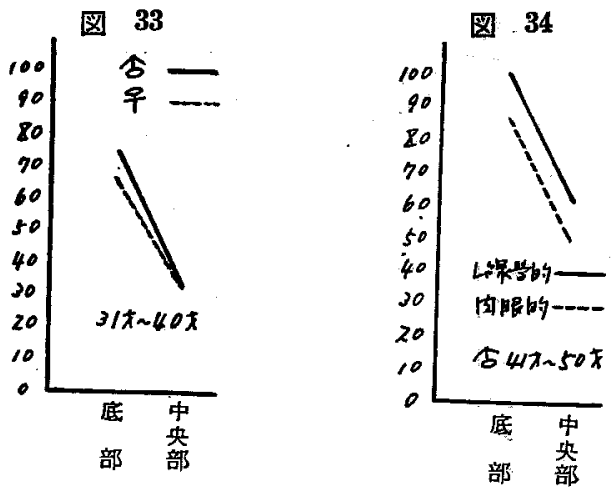

図 35

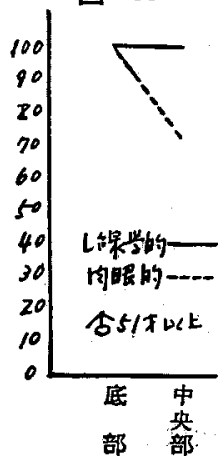

图 36

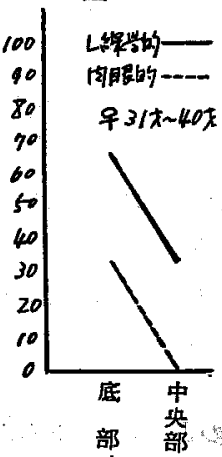


増 山論 文 附図 (第 2報) (I)

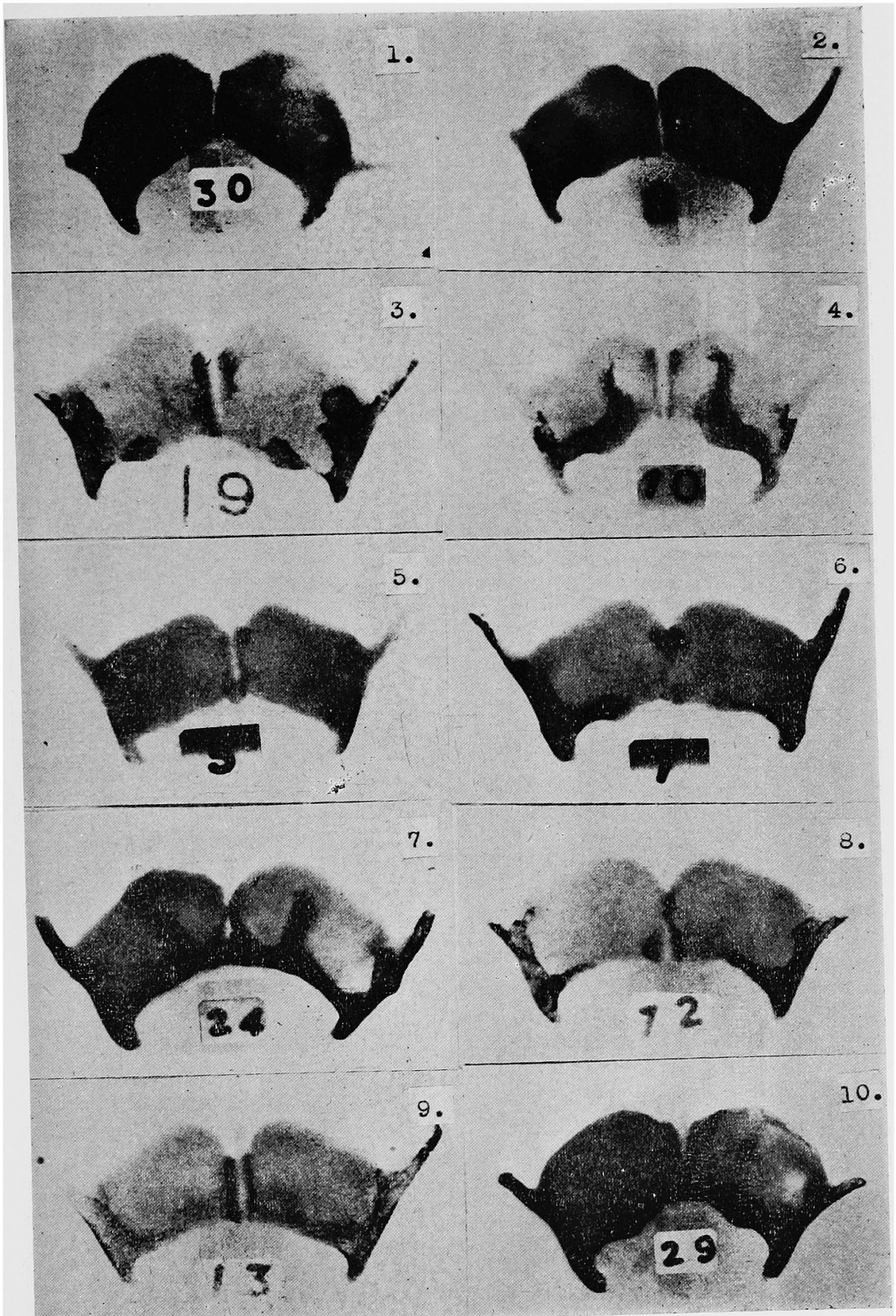


増 山 論 文 附 図 (第 2 報) (\|)

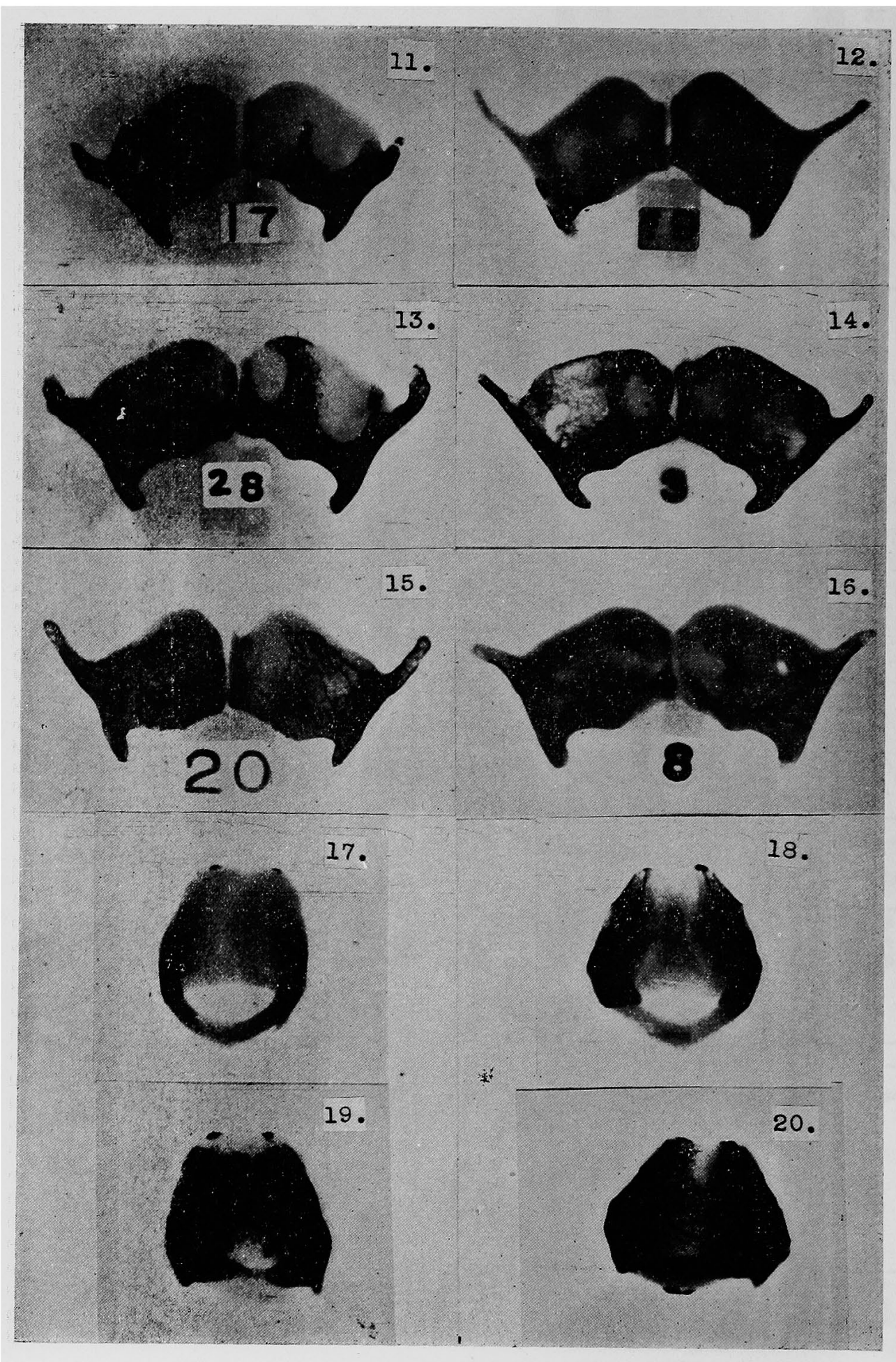


增 山論 文 附図（第 2 報）（价）

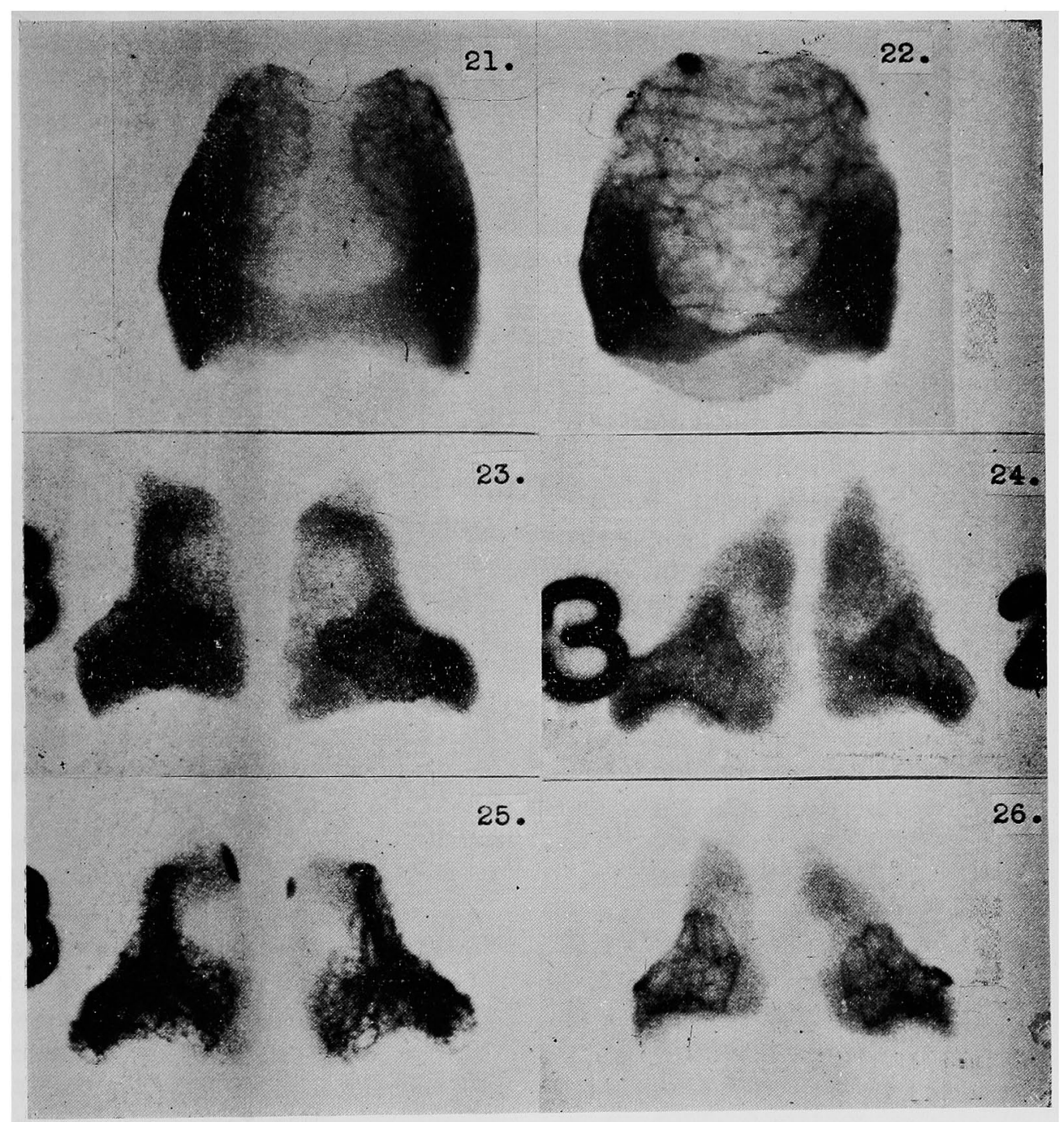




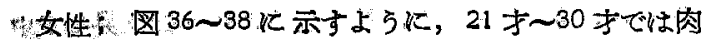
眼的には全然認められず，全年代を通じてレ線学的の方 が勝れている。
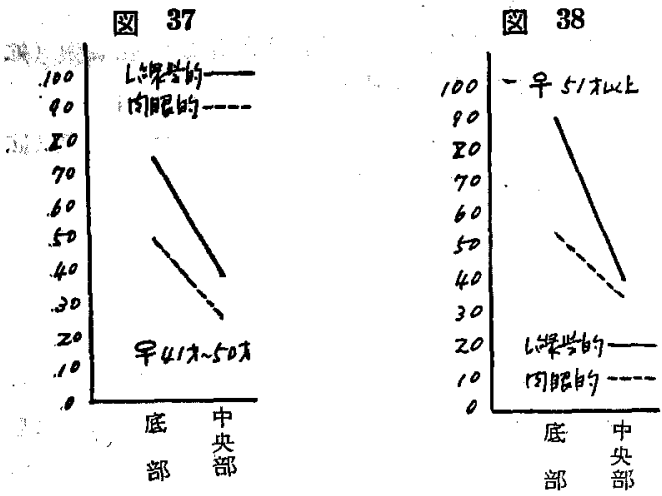

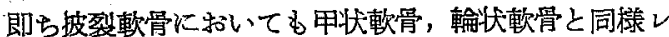
線学的観察の方が肉眼的観察上り優つて和り，乙か子肉 眼的観察では判然と軟骨表面に現われず，大部分が軟骨 内部に着色部を諗め，男性ではこの着色部が殆んどレ線 像と一致するが，女性では着色部の範囲は狭小であり， その周囲を針认て検查すると殆んどレ線像と一致する。 即ち披裂軟骨に和ける化骨部着色は他の 2 軟骨に比軟し 不鮮明で，殊に女性において然りである・

\section{IV. 結 論}

九州出身の的人㜊頭男 30 例, 女 20 例, 計 50 例の㩔 頭軟骨沉就いてレ線学的並びに肉眼的観察を行つて，次 の結果を得た。

1. 各軟骨に抬ける化骨の進行状態は凡そ一定の順序 と形式を示し，年令の増加と共に漸次進展する。

2. 各軟骨に猢ける化骨の性別差異は，甲状軟骨では 著明であり，輪状軟骨，披裂軟骨では著明でない

3. 甲状軟骨に和いて化骨核の最初に出現する部位は， 男性では下角基部及び下角基部後緑部，女性では下角基 部の高さで後縁の近く，輪状軟骨に和いては男女共披裂 関節面外側又は内側に，披裂軟骨に括いてて男女共底部 殊江筋突起部である・

4. 化骨現象の レ線学的観察と肉服的観察では前者が や優っている。

即ち甲状軟骨においては男女共肉眼的に化骨部着色は 判然としているが，レ線学的比比輍しや〉化骨出現範团 济狭く，輪状軟骨に和いても男女共肉眼的にや小小さい が，男性では透かして見学る籍囲を加えると両者は殆え ぞ一致している・披裂軟骨に括いては肉腿的に判然と軟
骨表面に現われず，他の2 軟骨に比し不鮮非で，大部分 が軟骨内部に群色部を認め，これは男性では殆んどレ線 像と一致するが，女性ではその篹囲が狭小である。

$$
\text { 文献 }
$$

第 4 報に凯裁する。

\section{(附図説明)}

図 1 6. 斘状軟霄（21才〜30才）

1）合：下笛基部及ど下笛基部後縟部の化尔核 (拡大 $2 / 3 x$ )

2）古：L 悡の化骨像（拡大 $2 / 3 \times$ )

3) $\delta$ : 下角の全化等像（桩大 $6 / 7 x$ )

4) 8 : 舌状の化骨乫起（拡大 $2 / 3 \times$ )

5）９：下角基部後緣に出現した化骨核（昿大 $3 / 5 \times$ ）

6）次：上解に進屡した化骨像（搪大 $3 / 5 x ）$

図 7 9. 甲状軟省 $(31$ 才 40 才)

7）す：下角より下緣及び後線に進み，更に゙前角部，

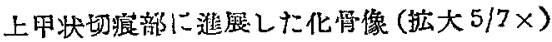

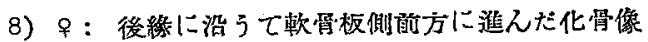
(搪大 $2 / 3 x$ )

9）우 一部下縁に沿うて進展した化骨核（拡大 $3 / 5 \times)$

図 10〜12. 甲状軟骨（41 オ 50才）

10）万：上線，上甲状切演部，前角部の相蛬合した化 骨像 (拡大 $2 / 3 x$ )

11)る：下緣より上方に征長した化骨羿起と，同時に 後緣より上算して上角に区るたた化骨像（拡大 $5 / 7 \times)$

12）ㅇ：板側央部一向つた化骨像（搪大 $5 / 7 \times$ ）

図 13〜16. 甲状軟省（51 才以上）

13）。：舌状の化骨突起が上淞近了迄及び，更に上甲 状切痕部に拡㖘し，同時に後糘より上角に及 己だ化霄像（搪大 $3 / 4 \times$ ）

14） 8 ：板側前・後部の軟骨島（拡大 $5 / 8 x$ )

15）市：板後部 $2 / 3$ の化雷像（実物大）

16）早：男性の皆合に見られるような舌状の化咸㔖起 （実物大）

図 17～22. 輸状軟督

17）。： 21 オ 30才，披裂関㓩面內側及び外側に出 現した化骨核（実物大）

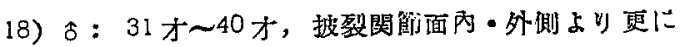
甲状関艒面附近迄相連結した化骨像(実物大)

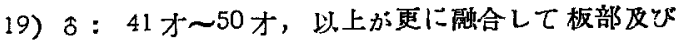
弓部上緣に攻んだ化骨像（実旸大） 


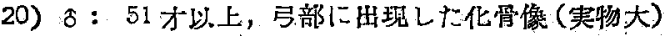

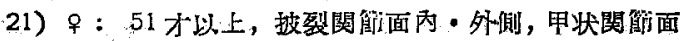
附近上り更に板部に及んているが，未だ正来 線で左右の融合を見ない化霄像（搪大 1.75 $x)$

22) 古：51才以上，板部正中心おいて在右相融合し た化骨像（搪大 $1.75 \times$ )

図 23〜26. 披裂軟, 量

第3 報 喉 頭 筋に就いて 大 $2.5 \times$ ) 大 $2.2 x$ )

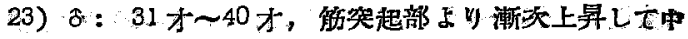
央部に及えた化骨像（拡大 $2.4 \times$ ）

24）す： 41 才〜50才，三角営の後側汽進展した他骨 像 (搪大 $2.5 \times$ )

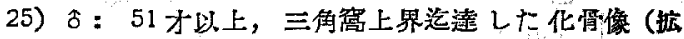

26）ㅇำ 51 オ以上，三角窩後側迄及んだ 化骨像（掂

の，交㕚したものがあり，表 1 に示すように離開したる のは $66.0 \% \pm 6.70 \%$ と過半数を占め，次いで接触したも のが $28.0 \% \pm 6.35 \%$ ，交叉したものが最る少なく $6.0 \%$ $\pm 3.36 \%$ で，男女共殆んそ゚その出現頻度に大差を認めな W.

2）直部・斜部の区分

輪状甲状筋の直部之斜部の分裂の状態を诨察子ると， 表 1 に示すように車側共に明瞕なるのは $58.0 \% \pm 6.98 \%$ で，男女共過半数を卢め，次いで不明膫なるのが $32.0 \%$ 土6.60\%でや>男性に多く，分裂が久如したものが男女 共 1 例宛，又 1 側の及明瞭なるのが男性では左側に 1 例，女性では左右に 1 例宛㒛められた。

2. 披 裂筋

九州日本人に括沙る披裂筋の分化の程度をWaldeyer の分類に従つて次の 3 度に分つて観察すると，表 2 の如 くである・

表 2 披裂筋 9 分化

\begin{tabular}{|c|c|c|c|c|c|c|c|}
\hline \multirow{2}{*}{\multicolumn{2}{|c|}{ ixin $x$}} & \multicolumn{2}{|r|}{ 古 } & \multicolumn{2}{|r|}{ 果 } & \multicolumn{2}{|c|}{ 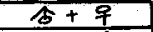 } \\
\hline & & 30 & $\%$ & 20 & $\%$ & 50 & $\therefore 86$ \\
\hline 米度 & / & ' & $\begin{array}{l}3.10 \pm 3.26 \\
3.3 \pm 326\end{array}$ & 0 & & 1 & $\begin{array}{l}20 \pm 1.98 \\
20 \pm 1.98\end{array}$ \\
\hline *2/ & $\begin{array}{l}\sqrt{2} \\
t a\end{array}$ & $\begin{array}{l}12 \\
15\end{array}$ & $\begin{array}{l}40.0 \pm 8.94 \\
50.0 \pm 9.13\end{array}$ & $\begin{array}{l}9 \\
7\end{array}$ & $\begin{array}{l}4510 \div 11.14 \\
35,0=4.78\end{array}$ & $\begin{array}{l}21 \\
22\end{array}$ & $\begin{array}{l}42,0=698 \\
440=702\end{array}$ \\
\hline 来了友 & $\begin{array}{l}\sqrt{2} \\
\frac{6}{6}\end{array}$ & $\begin{array}{l}17 \\
14\end{array}$ & $\begin{array}{l}567 \pm 903 \\
467 \pm 9.11\end{array}$ & 11 & $\begin{array}{l}5510 \pm 498 \\
65.0 \times 478\end{array}$ & & $\begin{array}{l}560 \pm 702 \\
540 \pm 705\end{array}$ \\
\hline
\end{tabular}

i）第 1 度；単に横部よりなるもの

ii）第 2 度；横部と斜部よりなるるの

iii）第 3 度；横部・斜部は勿論，更に披裂㬋頭蓋 筋を有するもの

袁 2 に示すよらに，横部と斜部に分れた第 2 度及び更 に披裂喉頭蓋筇を伴なつた第 3 度とが多く，両者で全例 の大部分を占める・この中です左側に数いては男娂第 3 度が多く（男性 $56.7 \pm 9.03 \%$ ，女性 55.0\%土4.98\%)， 右側に扔いては男性は第 2 度㠰見掛上多い傾向があり， 
㛗性は第3度が多い。而して単に横部のみよりなる第 1 度は男性で左右 1 例宛見られたのみである。

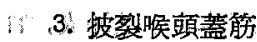

披裂筋斜部の連続として又は独立して披裂軟骨尖端よ り、披裂喉頭蓋七ダを前上方に走つて喉頭蓋軟骨に達する 披裂喉頭蓋筋の存在率を観祭すると，表 3 に示すように 32 例 $64.0 \% \pm 6.79 \%$ 飞执い、て認められ，性別的には男性 よりむ女性にや上多い傾向があり，更に側別的には両側 に存在するものが最も多く $(46.0 \%)$, 左側のみに存在す るものが男女共に $10 \%$ 程度に見られ，右側のみ存在 するものは女性に 4 例認められたのみである。

表 3 披裂䒨頭蓋觔の存在

\begin{tabular}{|c|c|c|c|c|c|}
\hline$x \frac{41}{x+2}$ & & 18 & & 9 & 金+ 辛 \\
\hline & 30 & $\%$ & 20 & $\%$ & $50 \%$ \\
\hline 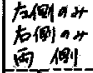 & $\begin{array}{r}2 \\
2 \\
17\end{array}$ & $\begin{array}{r}67 \pm 456 \\
67 \pm 456 \\
567 \pm 2.05\end{array}$ & $\begin{array}{l}0 \\
2 \\
9\end{array}$ & $\begin{array}{l}10,0 \pm 671 \\
4500,112\end{array}$ & $\begin{array}{rr}2 & 40 \div 2,77 \\
4 & 80 \pm 384 \\
26 & 52.0 \pm 707 \\
\end{array}$ \\
\hline 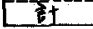 & 21 & $700 \div 87$ & ii & $55,0 \pm 71,12$ & $320640=6.79$ \\
\hline
\end{tabular}

4. 甲状堠頭蓋筋

九州日本人にては本解の存在ば隿 4 に示すよ 5 に, 18 例 (36.0\%) に招いて諗められ，性別的に大差はない。 側別的には両側に存在するものが $22.0 \%$ て最も多く， 左側のみに存在するものが両性共に $10 \%$ の同率を示し， 右側のみに存在するむのは最む少ない(4.0\%).

表 4 甲状喉頭盖筋の存在

\begin{tabular}{|c|c|c|c|c|c|c|}
\hline . & \multicolumn{2}{|r|}{$\delta$} & \multicolumn{2}{|r|}{ q9 } & \multicolumn{2}{|c|}{$5+7$} \\
\hline & 30 & $\mathscr{\%}$ & 20 & 9 & 50 & $\%$ \\
\hline 两 倒 & $\overline{8}$ & $267 \pm 808$ & 3 & $15,0 \pm 7.99$ & 11 & $220 \pm 5.51$ \\
\hline 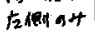 & 3 & $10.0 \pm 5.48$ & $z$ & $10.0 \pm 641$ & 5 & 10024,24 \\
\hline 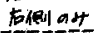 & 1 & $3.3 \pm 3.26$ & 1 & $50 \leq 4 \leq 28$ & $z$ & $40 \div 279$ \\
\hline के & $1 \overline{2}$ & $400 \pm 8.94$ & 6 & $30.0 \pm 10.25$ & 18 & $86.0+679$ \\
\hline
\end{tabular}

\section{5. 斜甲状披裂筋}

本笳は表5に示与よ5に，13例 (26.0\%) に和いて諗 められ，性别的には両性間に大差なく，更に側別的には 両側に存在するすのと1側のみに存在するすのに和いて は，男性では後者が多いのに反し，女性では両者夫ょ 2 例宛諗められて差異はない。

表 5 斜甲状披裂凘の存在

\begin{tabular}{|c|c|c|c|c|c|}
\hline & \multicolumn{2}{|r|}{$\hat{5}$} & \multicolumn{2}{|r|}{9} & $5+9$ \\
\hline-2 & 30 & $\%$ & 2.0 & $\%$ & $50 \%$ \\
\hline 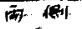 & 2 & $67 \times 456$ & $z$ & $100 \pm 671$ & $20 \pm 383$ \\
\hline Fat lar & 4 & $13.3 \pm 6.96$ & & $50: 4: 28$ & $100=424$ \\
\hline 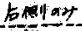 & 3 & $10.0 \pm 5,4 \pi$ & & 505482 & $-\frac{Z 0}{20} \pm 35$ \\
\hline 计 & 9 & $20.0 \pm 8.37$ & 4 & $20,0 \pm 3.94$ & $26,0 \pm 6,20$ \\
\hline
\end{tabular}

\section{6. 申状披裂筇}

甲状披裂筋の分化は多種多㴍で，これを明確に分類す る事は仲ふ困難である・故に筆者は表層部即ら外甲状披

裂筋の箊線維を調査し，更に斜甲状披裂筇の有無により 図１に示方上らに 4 型に分類した。

图 1 甲披裂得の形種
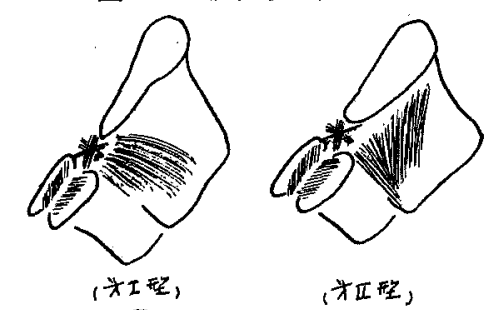

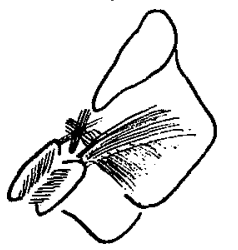

米西瑟

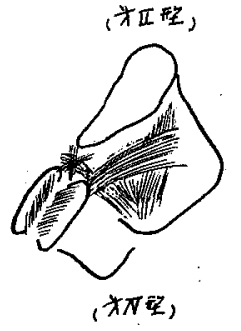

1）第 I 型；甲状披裂筇の筋線維が甲状軟骨前角部及 びその附近より後方に，水平文はや小下方に後走して披 裂㳄骨筇突起更び披裂軟骨外緑に附着し，又は披裂符横 部に筋性に移行し所謂横走型を示すもの.

2）第 II 型; 第 I 型と同様に起始した筋線維は，最下 部の線維が披裂軟咸穊突起に附着する外，大部分の線維 は後上方に放散し，所謂街走型をなするの・

3）第正型；第 I 型の籍線維の上に甲状軟搰板上縁の 近くより後下方に走り，披裂軟骨筋突起に附着卞る所謂

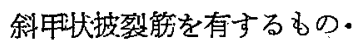

表 6 甲状披裂蝣々型

\begin{tabular}{|c|c|c|c|c|c|c|}
\hline \multirow{2}{*}{\multicolumn{2}{|c|}{ 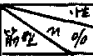 }} & \multicolumn{2}{|r|}{5} & \multicolumn{2}{|r|}{9} & 占+千車 \\
\hline & & 30 & $\%$ & 20 & $\%$ & $50 \%$ \\
\hline \multirow{2}{*}{$* 2=2$} & $\mid \begin{array}{l}\frac{1}{2} \\
b\end{array}$ & $\begin{array}{l}16 \\
17\end{array}$ & & & & $\begin{array}{ll}28 & 56.0 \pm 702 \\
30 & 600 \pm 0.93\end{array}$ \\
\hline & $B$ & 33 & $55,0 \pm 043$ & $z 5$ & $625 \pm 7.66$ & $58580 \pm 494$ \\
\hline \multirow[t]{2}{*}{ 为正星 } & $\begin{array}{l}\sqrt{2} \\
5 \\
6\end{array}$ & & & & $\begin{array}{l}250 \pm 9.69 \\
200 \pm 294\end{array}$ & $\begin{array}{ll}13 & 26,0 \pm 021 \\
2 & 240 \pm 604\end{array}$ \\
\hline & 2 & 16 & $26.7 \pm 571$ & & $225+6.60$ & $25 \quad 25.0 \pm 4.34$ \\
\hline \multirow[t]{2}{*}{ 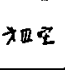 } & $\begin{array}{l}\sqrt{2} \\
b\end{array}$ & 3 & & & $\begin{array}{l}15.0 \pm 799 \\
150 \pm 299\end{array}$ & $\begin{array}{l}6 \\
7 \\
7\end{array}$ \\
\hline & {$[4$} & 7 & $11.7 \pm 415$ & 6 & $15,0 \pm 5,65$ & $100+3,36$ \\
\hline \multirow{2}{*}{$* \pi z_{2}$} & $\begin{array}{l}t_{2} \\
t_{2}\end{array}$ & & $\begin{array}{l}10.0 \leqslant 5 \\
3.3 \pm 3 .\end{array}$ & $a$ & & $\begin{array}{l}6.0+216 \\
20.2108\end{array}$ \\
\hline & it & 4 & $67 \pm 3.23$ & 0 & & $40 \cdot 196$ \\
\hline
\end{tabular}

4）第 $V$ 型； 第 II 型の筋線維の 上に第 II 型同㨾甲状披 裂祽を有するもの・

即ら表6に示すように，第I型が過半数を占めて最も 多く(58.0\%)，以下第 II 型，第 III型，第 $\mathbb{N}$ 型の順で男 女殆えど差異を認めない. 又外甲状披裂筋の走行より見 た埸合の横走型では男女共に横走型が多い. 


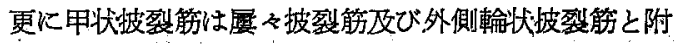
着し，又稀に後輪状披裂等と附着するもので，その中で も披裂筋との附着は表 7に示すように，96.0\%に㧅て 見られ，男女共両側に認められたものが男性 $83.3 \% \pm$ $6.81 \%$ ，女性 $85.0 \% \pm 7.99 \%$ と高率を示している。

表 7 甲状披裂的と披裂筋との関你

\begin{tabular}{|c|c|c|c|c|c|c|c|}
\hline \multirow{2}{*}{\multicolumn{2}{|c|}{$\frac{\pi}{\%}$}} & \multicolumn{2}{|r|}{5} & \multicolumn{2}{|r|}{9} & \multicolumn{2}{|c|}{$5+9$} \\
\hline & & 30 & $\%$ & 0 & $\%$ & 50 & $\%$ \\
\hline \multirow{4}{*}{$\begin{array}{l}\text { 行 } \\
\text { 勇 } \\
3 \\
\\
\end{array}$} & $\sqrt{2}$ & & & & & 5 & \\
\hline & t & & & 0 & & 1 & \\
\hline & 百 & 25 & $z 2.3 \pm$ & 17 & $850 \pm 799$ & 42 & $840 \pm 5.19$ \\
\hline & t & $2 \overline{9}$ & $90.7 \pm 3$ & 19 & $9550+48 x$ & 48 & $940+27 b$ \\
\hline \multicolumn{2}{|c|}{ 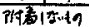 } & $\frac{1}{1}$ & $3.3 \pm 3.26$ & 1 & $5.0=4.88$ & 2 & $40+276$ \\
\hline
\end{tabular}

比 較:

男女間に著しい差兾を諗めない場合はずでて男女合計 した成續を以て比較し，特に支那人に沶いては佐山， Waldeyer の成績を集計したものを使用した・

1. 輪状甲状筋

1) 左右の関保

両側輪状甲状筋が接触したもの，離開したもの，交叉 したもの土中，表８に示すように九州日本人，支那人， 欧洲人共に離開したものが夫ょ過半数を゙占め，次いで接 触したもの，交止したものは最も少ないな特九州日本 人に括いて離開したものは欧洲人より少なく支那人に比 して多い.文接触したもの及び交攴したすのは Grabert の Herero-Hottentot 人の $80 \%$ に較へ三者共約半数に 過ぎず九州日本人に拁いては支那人に比して少なく欧洲 人より多い.

表 8 輪 状甲状筋比輘

\begin{tabular}{|c|c|c|c|c|c|c|c|c|}
\hline \multirow{3}{*}{\multicolumn{2}{|c|}{ 形焦 }} & \multirow{2}{*}{\multicolumn{2}{|c|}{$\frac{n+416 \text { 本 }}{\text { 增 }}$}} & \multirow{2}{*}{\multicolumn{2}{|c|}{ 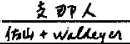 }} & \multirow{2}{*}{\multicolumn{2}{|c|}{$\frac{\text { EP stll } \alpha}{\text { Walleges }}$}} & \multirow{2}{*}{$\frac{\theta+\alpha}{R+13}$} \\
\hline & & & & & & & & \\
\hline & & 50 & $\%$ & 60 & $\%$ & 55 & $1 \%$ & 77 i 8 \\
\hline \multirow{2}{*}{ 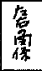 } & 梅妕 & 14 & $22.0 \times 6.35$ & 23 & $32.3 \pm 4.28$ & 11 & $20.0 \pm 5.39$ & \\
\hline & 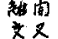 & $\begin{array}{r}33 \\
3\end{array}$ & $\begin{array}{r}66,0 \pm 470 \\
60 \pm 3.36\end{array}$ & 31 & $51.7 \div 645$ & $\begin{array}{r}42 \\
z\end{array}$ & $\begin{array}{r}76.4 \pm 573\} \\
3.6 \pm 351\end{array}$ & \\
\hline \multirow{4}{*}{ 㕝 } & & 2 & 40.277 & 1 & $17 t 167$ & $z$ & $3, b: 2.51$ & \\
\hline & 明㖟 & 1 & $2.0 \pm 1.92$ & $z$ & $3.3 \pm 2.31$ & 3 & $5.5 * 3.07$ & $299 \pm 522$ \\
\hline & $\frac{1}{7}$ & $\frac{16}{16}$ & $320 \neq 660$ & 0 & 0 & 12 & $z 1.2 \pm 5.57$ & $7 a / \pm \$ 22$ \\
\hline & $\begin{aligned} 4 R \\
40\end{aligned}$ & $z$ & $40 \div 2.77$ & $z$ & $3.2 \pm 2.27$ & 15 & 27300.01 & 0 \\
\hline
\end{tabular}

2) 直部・斜部の区分

表 8 に示すよ5に，両側共に直部と斜部の区分明瞭な ものかi，九州日本人，支那人，欧洲人共㵊も多く，中 です支那人に括いては直部及び斜部に分化したるのが殆 えぞであるのに対し，九州日本人では $58.0 \%$ と過半数， 欧洲人では $41.8 \%$ と半数に過ぎず，日本人（尾関）では 更に少ない.

な和欧洲人に就いては Rühlman は直部と斜部は殆 えど区別なしと述べ，Möller は直・斜部の区分明瞭な
ものは僅少であるとしているが，Führinger は27.0\% に認めると記載している如く相当の差異が桼められる。 直・斜部の区分不明腺なるのは九州日本人之欧洲人，日 本人 (尾関) に見られ，日本人（尾関）では $70.1 \%$ と最

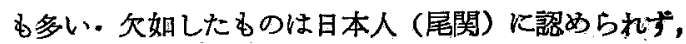
九州日本人代支那人に2 例宛見られたのみであるが， 欧洲人に拉いて $27.3 \%$ で最多い. 即ち支那人に扎い ては両側共に直部不び斜部に分化したものを常としてい る.

\section{2. 披 裂 管}

分化の程度を前述の分類により比較すると，表9に示 すよらに，九州日本人では第 3 度最も多く，第 2 度これ に次ぎ，第1'度は左右 1 例宛見られたのみで，これに対 し支那人では第 1 度，第 3 度は殆んぞ同数で，第 2 度は や\少ないが大体に括いて三者類似し，欧洲人では九州 日本人と同様に第 3 度, 第 2 度の順で第 1 度は最す少な い換言すれば，分化の程度が進んで斜部を有するすの は，九州日本人では 98.0\%であるのに対し；支制人で は65.8\%，欧洲人では $79.1 \%$ 九州日本人に和いては 他二人種に較心高率を示している。

表 9 披裂觔の分化比較

\begin{tabular}{|c|c|c|c|c|c|c|c|}
\hline \multirow{3}{*}{\multicolumn{2}{|c|}{$\frac{1}{x}$}} & \multicolumn{2}{|c|}{ 几世中日人 } & \multirow{2}{*}{\multicolumn{2}{|c|}{ 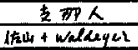 }} & \multirow{2}{*}{\multicolumn{2}{|c|}{ 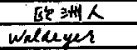 }} \\
\hline & & \multicolumn{2}{|c|}{$t$} & & & & \\
\hline & & 50 & $\%$ & 60 & $\%$ & 55 & 46 \\
\hline 粉度 & $\begin{array}{l}\sqrt{2} \\
t \\
t\end{array}$ & & $\begin{array}{l}20 \pm 1.92 \\
2.0 \pm 191\end{array}$ & & & & \\
\hline & EF & $z$ & $2.0 \pm 1.40$ & 41 & $342 \pm 434$ & 23 & $20.9+237$ \\
\hline 江度 & $\begin{array}{l}F_{1} \\
t\end{array}$ & & $\begin{array}{r}420 \pm 698 \\
440 \pm 702\end{array}$ & & & & \\
\hline & $E$ & 43 & $430 \pm 495$ & 36 & $30,0+4.18$ & 37 & $3,3,6<451$ \\
\hline 来了度 & $\begin{array}{l}\sqrt{2} \\
t_{2}\end{array}$ & $\begin{array}{l}28 \\
27 \\
\end{array}$ & $\begin{array}{l}540=202 \\
540 \pm 205\end{array}$ & & & & \\
\hline & 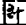 & 75 & $55,0 \pm 498$ & 43 & $36.8 \pm 4.38$ & 50 & $4515=474$ \\
\hline
\end{tabular}

\section{3. 披裂喉頭蓋筋}

九州日本人，支删人に和ける披裂堠頭蓋筋の存在率は 表 10 K示すよらに，ほら゙同率で，欧洲人に較べや小高 率を示している・更に側別では各人種共両側に存在する むのが多いが，支那人に抹いては九州日本人，欧䛍人に 比しや低率を示している.

表 10 披裂喉頭蓋筋比䡆

\begin{tabular}{|c|c|c|c|c|c|c|}
\hline \multirow{3}{*}{$x \frac{100}{\%}$} & \multirow{2}{*}{\multicolumn{2}{|c|}{ 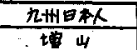 }} & \multirow{2}{*}{\multicolumn{2}{|c|}{$\frac{12 \alpha}{1 / 2 d 4}$}} & \multirow{2}{*}{\multicolumn{2}{|c|}{$\frac{\text { Géth }}{\text { Milla }}$}} \\
\hline & & & & & & \\
\hline & 50 & $\%$ & 50 & \% & 40 & $\%$ \\
\hline 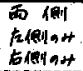 & $\begin{array}{r}23 \\
5 \\
4\end{array}$ & $\begin{array}{l}40.017 .05 \\
10.0 \pm 424 \\
80 \pm 7 x^{3}\end{array}$ & $\begin{array}{r}14 \\
10\end{array}$ & $\begin{array}{l}220 \pm 0.35 \\
120 \pm 503 \\
200 \pm 566\end{array}$ & $\begin{array}{c}13 \\
3 \\
3\end{array}$ & $\begin{array}{r}32.5 \pm 241 \\
7.5 \pm 416 \\
25 \pm 416\end{array}$ \\
\hline 敦 & 32 & $640+678$ & 33 & $640 \pm 470$ & 19 & $475=789$ \\
\hline
\end{tabular}

4. 甲状披裂筋

前述の分類により各人種を比較すると，表11 に示す 
よ5た，九州日本人では第 I， I， 四，N型の順に多 く，これに対し支那人及び欧洲人では第W， III， II， I 型の順に全く反対の傾向を示している・これは第I型及 び第』型即ち斜甲状披裂筋を有しないるのは九州日本人 に控いては $83.0 \%$ ，第四型及び第 $\mathbb{N}$ 型即ら斜甲状披裂筋 を有するものは $17.0 \%$ であり，これに反し支那人，欧 洲人に拉いては $70.8 \% ， 84.5 \%$ と斜甲状披裂筋の分化し たものが多い。

表 11 甲状披裂筋々型比轌

\begin{tabular}{|c|c|c|c|c|c|c|c|}
\hline \multirow{3}{*}{\multicolumn{2}{|c|}{ 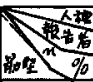 }} & \multirow{2}{*}{\multicolumn{2}{|c|}{ 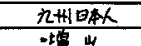 }} & \multicolumn{2}{|c|}{ 支拜K } & \multicolumn{2}{|c|}{ E是洲人 } \\
\hline & & & & $6 f_{14}$ & walleyen & & enyed \\
\hline & & 50 & $\%$ & 60 & $\%$ & 55 & $4 \%$ \\
\hline \multirow{2}{*}{ 头工型 } & $\begin{array}{l}\sqrt{2} \\
6\end{array}$ & & $\begin{array}{l}560 \pm 702 \\
600 \pm 693\end{array}$ & $\begin{array}{l}8 \\
9\end{array}$ & $\begin{array}{l}13.3 \pm 4.38 \\
15.0 \pm 462\end{array}$ & & $\begin{array}{l}0.5 \pm 3.07 \\
4.1 \pm 3.66\end{array}$ \\
\hline & Bt & $5 x$ & $520 \pm 4.4$ & 17 & $142 \pm 3.19$ & $\bar{z}$ & $7 j \pm 24 x$ \\
\hline \multirow{2}{*}{ 为叫型 } & $\mid \begin{array}{l}\sqrt{2} \\
t\end{array}$ & & $\begin{array}{l}260 \pm 0.21 \\
240 \pm 0.04\end{array}$ & $?$ & $\begin{array}{l}11.7 \pm 4.15 \\
18.3 \pm 4499\end{array}$ & & $\begin{array}{l}0.1 \pm 3.66 \\
3.7 \pm 2.54\end{array}$ \\
\hline & 针 & 25 & $25.0 \pm 434$ & 18 & $15,0 \pm 2.26$ & 9 & $22 \pm 262$ \\
\hline \multirow{2}{*}{ 来西醒 } & $\begin{array}{l}5 \\
6\end{array}$ & & $\begin{array}{l}120 \pm 459 \\
140 \pm 499\end{array}$ & & $\begin{array}{r}367 \pm 422 \\
23.3 \pm 5.46\end{array}$ & $\begin{array}{r}7 \\
15\end{array}$ & $\begin{array}{l}3 a 1 \pm 6.11 \\
272 \pm 6.00\end{array}$ \\
\hline & 10 & 13 & $130 \pm 336$ & 36 & $30.0 \pm 418$ & 32 & $291 \pm 434$ \\
\hline \multirow{2}{*}{$\forall N F_{2}$} & $\begin{array}{l}\sqrt{2} \\
t\end{array}$ & & $\begin{array}{l}40 \pm 236 \\
200193\end{array}$ & & $\begin{array}{l}283 \pm 628 \\
433 \pm 640\end{array}$ & 30 & $\begin{array}{l}544 \pm 672 \\
56.4 \pm 669\end{array}$ \\
\hline & B & 4 & $40 \pm 1.96$ & 49 & $40.8 \pm 4.48$ & $6 i$ & $55.4=4.74$ \\
\hline
\end{tabular}

更に又，外甲状披裂筋の走行のみより見た場合，第 I， II 型は横走型，第 $\mathbb{I} ， \mathbb{I}$ 型は縦走型であつて，九州 日本人では横走型が縦走型上りも多く，これに対し支那 人，欧洲人では横走型が縦走型よりる少ない.

表 12 甲状披裂筋と披裂筋との関保比搭

\begin{tabular}{|c|c|c|c|c|c|c|c|}
\hline \multirow{3}{*}{\multicolumn{2}{|c|}{$\frac{x+\frac{9}{6}}{\%}$}} & \multicolumn{2}{|r|}{ n州本人 } & \multicolumn{2}{|c|}{ 支 } & \multicolumn{2}{|c|}{ 欧洲人 } \\
\hline & & \multicolumn{2}{|r|}{ 境山 } & \multicolumn{2}{|c|}{ dFat + walleys } & \multicolumn{2}{|c|}{ waldequs } \\
\hline & & 50 & $\%$ & 60 & $\%$ & 55 & $\%$ \\
\hline \multirow{4}{*}{ 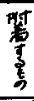 } & $/ 2$ & 5 & $10.0 \pm 424$ & 8 & $13.3 \pm 4.38$ & 13 & $23.6 \pm 5.73$ \\
\hline & 后 & 1 & $2.0 \pm 1.98$ & 16 & $267 \div 5.71$ & 9 & $144 * 499$ \\
\hline & 而 & 42 & $x 40 \pm 5.19$ & $2 z$ & $3 b 7 \pm 422$ & 20 & $344 \leq 649$ \\
\hline & 4 & 48 & $96.0+2.77$ & 46 & $76.7+5.46$ & 42 & $76.4 \pm 5.73$ \\
\hline \multicolumn{2}{|c|}{ nft } & 2 & $40 \div 277$ & 14 & $23.3 \times 546$ & 13 & $236+5.73$ \\
\hline
\end{tabular}

次に甲状披裂筋と披裂筋との附着は表 12 に示すよ5 に，九州日本人 $96.0 \%$ ，支那人 $76.7 \%$ ，欧洲人 $76.4 \%$ と九州日本人が最も高率を示している。

\section{5. 後輪状披裂筋}

後輪状披裂觔は比較的一定したものであるが，佐山は
起始部及び附着部に若干の破格を見る事があると記載し ている・即ち角輪状筋では佐山は支佛人男子に沶いて $20.0 \%$ ，Waldeyer は欧洲人男子に繥いて $9.1 \%$ を認め， 角披裂筋で恃佐山は $6.0 \%$ ，Waldeyer は欧洲人女子 1 例においてこれを認めたのみであると言い，筆者は全例 にいずれの破格も発見できず，後輪状披裂筋の破格は支 那人に著しく頻度が高いようである。

\section{III. 粉括並びに結論}

九州出身の成人㬋頭男 30 例, 女 20 例, 計 50 例の堠 頭筋に就いて調查し，男女比較は勿論，欧洲人，支那人 及び一部に礼いて他地方出身の日本人と比較した。

1）九州日本人に和いて 輸状甲状筋の形態は左右離開 したものが夫ょ過半数を占め，交叉したるのは少ない が，これは他の人種にても同様である・但し離開型の頻 度は九州日本人に怙いては欧洲人上り少なく，支那人に 较べて多い，直部と斜部の区別は日本人（尾関）を除き， 九州日本人，支那人，欧洲人共に雨側共明嘹なものが多 く，中でも支那人に执いて高率を示している・

2）披裂筋は横部之斜部に区分したものが殆んど 全例 に見られ，横部のみよりなるるのは2.0\% で，支那人， 欧洲人に比較し高率を示している。

3) 披裂堠頭蓋筋の存在率は，九州日本人 $(64.0 \%)$ 及 び支那人 $(66.0 \%)$ では殆んど同率で，欧洲人 $(47.5 \%)$ に較べや」高率を示している.

4）甲状喉頭蓋筋は $36.0 \% \pm 6.79 \%$ に扎いて，更に斜 甲状披裂筋は $26.0 \% \pm 6.20 \%$ において認められる。

5）甲状披裂筋は九州日本人では横走型が多い（男女 共事半数)のに反し，支那人，欧洲人では縱走型が多く 存在し，甲状披裂筋と披裂筋との附着は九州日本人が最 も高率 $(96.0 \%)$ を示している.

$$
\text { 文献 }
$$

第 4 稂に記载する。

$$
\text { 第 } 4 \text { 報 喉 頭 腔に就いて }
$$

\section{舶言}

従来㬋頭腔の形態学的観察は人類学的に頗る興味ある 問題であるために，これが観察種々の方洗によつて試 みられている・即ち Zeller (1871) は石育泥を，Weinberg (1875) はバラフインを注入し, Aeby (1880), Passavant (1884) は Rosè の合金を使用し, Müller
（1884）は黄蠟とパシフインの混合物を用い，Hansemann (1898) は黄蛝，松脂及びバラフインの混合物を使 用し，又 Bartels (1905) はWood の合金を用いたが， これ等はいずれも真の涘頭腔を示するのではなからた。 その後佐山（1931）はセルロイド溶液の遠心力応用鋳型 を案出し，喉頭腔つ実際に近い鋳型を得たが，セルロイ 


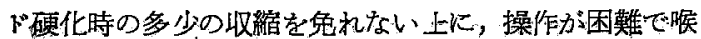
頭を精查するには適当でない。

こ\に和いて筆者は極めて正確な印象亡強力な弾性を

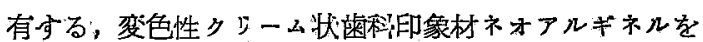
用いて真の臇頭腔を作成し，直接計湘し得る部分に和い ては計器により計測し，その他は単に有無，形状等を精 しく調查すると共に，既存の他人種に就いての成續と比 較対䀡した。

\section{I. 研究材料並びに研究方法}

材料湔報告に执いて記載した九州成人男 30 例，女 20 例, 計 50 例である。

方法は先ず㗋頭を輸状軟骨板部正中において縦断し，

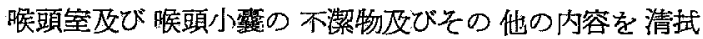
し，水分を除去した後，ホオアルギネルを喉頭腔内注 入した直後，輪状軟骨正中の切開縁を整復証着させ，全 皖頭を旧位に復し硬化した後，前記の輪状軟骨板部切開 縁より倨頭を開き，細心の注意を以て取り出し，直ちに 計測した・な法調查した項目は次の如くである・

1. 計 测 部 位

1）喉頭口：矢状径と横径に分けた。

i）矢状径；披裂間切痕之喉頭葐上緑正中点間の 直線距離.

ii）僙径；両側披裂㬋頭蓋七ダ間の最大距離.

2）声門下腔：輪状軟骨下縁儿和ける口径（矢状 埾と横径)を計测した・

3) 声門裂：所謂中間位 Zwischenstellung に 扣行万兩側声帯ヒダ間中央部の離開距離 (横堡).

4）前庭裂：左右室七ダ間中央部に括ける離開 距離 (横径).

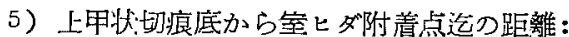

6) 上甲状切痕底から声帯七が附着点迄の距離：

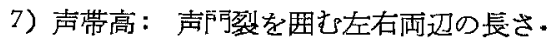

8)㬋頭室々閒：高さ，幅，潹さに分けた。

i) 長さ；至入口の前後径.

ii）幅；窒七ダと声带ヒダ間の最大距離.

iii）哚さ；室七ダ遊離緑中央部より喉頭室側壁运の 距離:

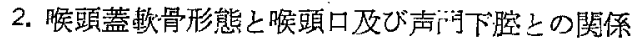

3. 前庭裂と声朒裂の比較

4. 谯 頭 窒

1）室问左右比較：左右同大つもの，右側大つもの， 左側大つむのに分けた。

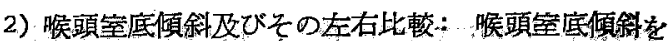
次の3 型に分けた。

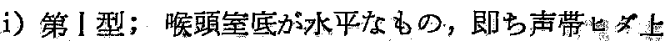
面と同一平面上にあるるの・

ii）第 II 型；声带より外上方に上昇したるの.

iii）第四型；声帯より下外方に傾斜したるの.

5.喉頭小覇

1) 左右比較:

2）人口径と窒朋長との比較:

3) 入口の位置:

\section{II. 成績と比較}

1. 喉頭踛計測值

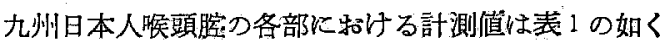
である・即ら声师裂を馀き他のすべての項目に扣いて， 計測値は女性より男性に和いて優るか又は優る傾向があ り，又男女共左右の計測値間には殆んど妻異を認めな w.

表 1 喉頭啌䛅·則值 (单位 $\mathrm{mm}$ )

\begin{tabular}{|c|c|c|c|c|c|c|c|c|c|c|c|}
\hline & & & & 古 & & & & 4 & & & s-9 \\
\hline 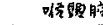 & 球獞 & & $m$ & $M \pm m$ & $\sigma$ & $v$ & $n$ & $M=m$ & $\sigma$ & $v$ & 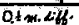 \\
\hline 婙 & & & $\begin{array}{l}30 \\
30\end{array}$ & $\begin{array}{l}23.9 \pm 0.71 \\
7.8 \pm 0.71\end{array}$ & 391 & $\begin{array}{l}1302 \\
2 / 76\end{array}$ & $\begin{array}{l}20 \\
20\end{array}$ & $\begin{array}{l}20.5 \pm \text { a.t } \\
13.8 \pm 487\end{array}$ & $\begin{array}{l}5 / 3 \\
259\end{array}$ & $\begin{array}{l}2412 \\
2469\end{array}$ & $\begin{array}{l}44+83 \\
40 \pm 0.7\end{array}$ \\
\hline 声切下膛 & & & $\begin{array}{l}30 \\
30\end{array}$ & $\begin{array}{l}146 \pm 0,99 \\
165 \pm 0,42\end{array}$ & $\begin{array}{l}242 \\
228\end{array}$ & $\begin{array}{l}1.453 \\
147\end{array}$ & $\begin{array}{l}20 \\
20\end{array}$ & $\begin{array}{l}11.9=0.77 \\
30 \neq 0.36\end{array}$ & 107 & 1403 & $\begin{array}{l}2.7=x-54 \\
35=0,55\end{array}$ \\
\hline 内 & & & 30 & $30 \pm 222$ & 120 & 39.27 & 20 & 24.20 .26 & Q,II & 4896 & $0.6 \times 0.34$ \\
\hline $2 \quad$ 庭 & 装 & & so & $\$ 2 \pm 0.46$ & $2,5^{4}$ & 45.24 & 20 & $25 \div 0.41$ & 1.85 & 52.77 & $67=a b 2$ \\
\hline 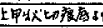 & 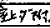 & 䇾 & 30 & $6,1 \pm 0,78$ & $2: 10$ & 3440 & 20 & $39 \pm 0.20$ & 291 & 231 & $22 \pm 0.43$ \\
\hline 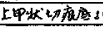 & 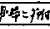 & et & 30 & $z 1 \pm 0.27$ & zos & 25.31 & 20 & sit \pm 0.23 & 102 & 1879 & $27 \times 0.44$ \\
\hline 声常 & & $\sqrt{2}$ & 30 & $18 I \pm 0.5 t$ & $3 . / Z$ & that & 20 & $1 \leqslant 4=0,53$ & 239 & s,55 & $44 \leq a>9$ \\
\hline & & $F_{2}$ & 30 & $\begin{array}{l}189=0.87 \\
1,1 \pm 0.43\end{array}$ & 2,35 & 1573 & 20 & $\begin{array}{l}15.2 \pm 0.45 \\
10.9=0.45\end{array}$ & 201 & $\begin{array}{l}2 \times 37 \\
(2), 2\end{array}$ & $\begin{array}{l}47 \pm 0.33 \\
* 2 \pm 0,62\end{array}$ \\
\hline & & 后 & 90 & $1 s 3=a .44$ & 240 & ts.te & 20 & $\mu, 1 \neq 0.46$ & 7 & 1868 & $42 * 964$ \\
\hline 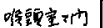 & 中 & Fiz & 30 & $32 \pm 233$ & $4 \times 1$ & 5669 & 20 & $a b \pm a \geq 0$ & azs & $5 t \leq 1\}$ & $16 \pm 0.3 x$ \\
\hline & & te & 30 & $34=0.36$ & 199 & SEA 3 & 20 & $2.1 \pm a 28$ & 1.26 & S\{.86 & $x_{3} \geq a k b$ \\
\hline & 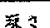 & $\sqrt{2}$ & 30 & $42 \pm a \geq 2$ & 123 & 2826 & 20 & $3.4 \pm 0.16$ & 0.72 & 2421 & $0,820.28$ \\
\hline & & 声 & 90 & $50 \pm 224$ & 1.29 & $25 \pi 4$ & 20 & $39=a_{21}$ & 0.94 & $z$ & Hif $=0.32$ \\
\hline & & $f_{2}$ & 30 & $68 \pm 040$. & 249 & 2225 & 20 & $50 \pm 0.34$ & $1+2$ & 20.40 & 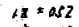 \\
\hline 促䤄小重 & & 招 & 30 & $22 \pm 0.38$ & 206 & 2277 & zo & $f 1=946$ & 205 & $22 i 2$ & $19=0.59$ \\
\hline & 染: & 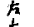 & 30 & $c 3=0.56$ & 306 & $f \pi 72$ & 20 & $B A \pm 0.13$ & 3.47 & 5261 & $2.5 \div 0.65$ \\
\hline & & $E$ & 30 & $50 \pm 0.44$ & $z<2$ & 45,40 & 20 & $34 \pm 0,38$ &, 72 & 1244 & $A x \operatorname{asc} x$ \\
\hline
\end{tabular}

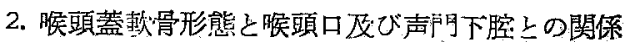
喉頭口及び声門下腔つ諸圣は，男女共夫くの喉頭の発

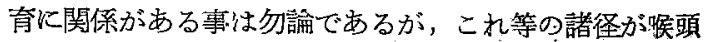
蓋軟骨の形態（第！報図 1 参照）といかなる関係がある かに就いて調查した。

即ち表 2 に示すよらに男性では e 型，女性では c 型 学除く他の各型中，㬋頭口に特いては両性共見掛上 $\mathbf{a}$ 型 に属するものが最も広く，b型これに次ぎ， d 型が最も 小さい，又声师下腔に特いては男女共矢状径ではd d るいは e 型が広く、これに較べ a, b 型はや〉狭く， 横径では男性は c 型，女性は a 型が広く，その他の各 型は男女共夫々殆んど美異を認めない.

3. 前庭裂と声門裂の比較 


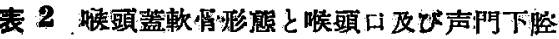
(策. 位 $\mathrm{mm}$ )

\begin{tabular}{|c|c|c|c|c|c|c|}
\hline \multirow{3}{*}{$t$} & \multirow{3}{*}{ 形 } & \multirow{3}{*}{$n$} & \multicolumn{2}{|c|}{ 唯融口 } & \multicolumn{2}{|c|}{ 事开㧤 } \\
\hline & & & 天状狂 & 社 & 文行任 & 程 \\
\hline & & & $M \pm m$ & $M \pm m$ & $M \pm m$ & $M \pm m$ \\
\hline \multirow{4}{*}{$\delta$} & $a$ & 20 & $30.4 \pm 0.92$ & $12.6 \pm 0.22$ & $144 * 0.54$ & $16.3: \pm 047$ \\
\hline & a & 5 & $292 \pm 0.91$ & $120 \pm 123$ & $144 \pm 0.36$ & $16.4 \pm 1.2 x$ \\
\hline & $C$ & 2 & $220 \pm 254$ & $120+254$ & $150 \pm 000$ & $190 \div 180$ \\
\hline & $\begin{array}{l}e \\
e\end{array}$ & 2 & $220 \pm 071$ & $15.5 \neq 4.35$ & $10.5 \div 0.35$ & $145 \pm 0.35$ \\
\hline \multirow{4}{*}{8} & a & 10 & $24.8 * 161$ & $147 \pm 068$ & $119 \pm 046$ & $13.5 \times 0.5$ \\
\hline & e & 7 & $21.1 \pm 175$ & $14.1 \pm 0.79$ & $11.4 \pm 0.75$ & $12.7 \div 0.4 \pi$ \\
\hline & $c$ & 1 & 26.0 & 5,0 & 13,0 & 12,0 \\
\hline & $\begin{array}{l}d \\
e\end{array}$ & $\begin{array}{l}2 \\
0\end{array}$ & $190 \pm 0.00$ & $125 \pm 177$ & $13.0 \pm 0.71$ & $13.0 \pm 1.50$ \\
\hline
\end{tabular}

前庭裂と声門裂とを比较すると，男性では2例，女性 では3例老除けば，すべて前者後者より大であるが， 個人的相違があり両者の比汢必ずしも一定でない。

表 3 前逞裂 対声 門裂

\begin{tabular}{|c|c|c|c|c|c|c|}
\hline \multirow{2}{*}{ 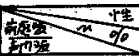 } & \multicolumn{2}{|r|}{ 秀 } & \multicolumn{2}{|r|}{9} & \multicolumn{2}{|c|}{$5+7$} \\
\hline & 30 & $\%$ & 20 & $\%$ & 50 & $\%$ \\
\hline $09<\mathrm{T}$ & $z$ & $6.7 \pm 456$ & 3 & $15,0 \pm 750$ & 5 & $10.0 \pm 4.24$ \\
\hline 1.0 & 4 & $133=420$ & $z$ & $10.0 * 0.71$ & 6 & 12004419 \\
\hline $11 \sim 15$ & 6 & $200=2.54$ & $z$ & 40.051295 & 14 & $22.0=241$ \\
\hline $1.6-20$ & 11 & $267 \pm 8.20$ & 7 & $35,0 \div 1068$ & 18 & $3400=699$ \\
\hline $21 \sim 25$ & 4 & $13,3 \pm 20$ & . & & 4 & $x \in:\{x\}$ \\
\hline $2.6 \sim 3.0$ & I & $33 \pm 3.26$ & 0 & & & $20 \pm / 18$ \\
\hline $311 \sim 25$ & $z$ & $\Delta .7=4.54$ & 0 & & $z$ & $40=377$ \\
\hline
\end{tabular}

即ら表 $3 に$ 示すように，前庭裂は声門裂の $1.6 〜 2.0$ 倍 が最も多く 18 例 (36.0\%)，次いで $1.1 〜 1.5$ 倍の 14 例 (28.0\%) の順で，2.1 倍以上は男性では7例諗められる が，女性では全く䜅められない、。

即ち㬋頭裂では男性は女性に較べ比軹的上部が大であ る.

4. 䐅頭室について

1) 倒服左右比較

九州人に和ける喉頭室門は表 4 に示すように男，性 では長さ，幅；梁さに括いてすべて右側が大なるものが 多く，次いて左右同大のもの，左側の大なるものは最も 少ない女性では長さ，幅，深さにおいて左右同大のも の，右側の大なるものが注ぶ同率で，左則つ大なるすの が最も少ないのは男性同様である。

表 4 喉頭室安閏左右比較

\begin{tabular}{|c|c|c|c|c|c|c|c|}
\hline \multirow{2}{*}{\multicolumn{2}{|c|}{ 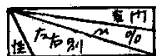 }} & \multicolumn{2}{|r|}{ E } & \multicolumn{2}{|r|}{ T } & \multicolumn{2}{|r|}{ 深 5} \\
\hline & & $n$ & $\%$ & & $\%$ & $m$ & $\%$ \\
\hline \multirow{3}{*}{$\hat{\delta}$} & 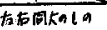 & 10 & $31.3 \pm 260$ & 9 & $900 \pm 837$ & $\bar{x}$ & $26.7 \pm \mathrm{g} 0 \mathrm{C}$ \\
\hline & alo & 14 & $46.7 \pm 4.11$ & 15 & & 17 & $56.7+604$ \\
\hline & Folentat? & $b$ & $200 \leq 730$ & $b$ & $20.0 \times 330$ & 5 & $167 \pm 6.21$ \\
\hline \multirow{3}{*}{9} & aln & 9 & $45.0 \pm 11.14$ & 8 & $40.0 \pm 10.95$ & 9 & $45.0 \pm 1214$ \\
\hline & bAent大ala & 8 & 40.0 Eiast & 9 & $45,0 \geq 1,14$ & 10 & $60,0,1118$ \\
\hline & F2, 但IKath & 3 & $150 \pm 750$ & 3 & $15,0+250$ & 1 & $5.0 \pm 4.8 x$ \\
\hline
\end{tabular}

2）喉頭室底傾斜及びその左右比較

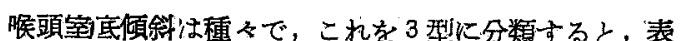
5 に示すようになる。

表 5 喉頭空底 傾 斜

\begin{tabular}{|c|c|c|c|c|c|c|c|}
\hline \multirow{2}{*}{\multicolumn{2}{|c|}{ 醒 }} & \multicolumn{2}{|r|}{ 枮 } & \multicolumn{2}{|r|}{9} & \multicolumn{2}{|c|}{$5+9$} \\
\hline & & 30 & $\%$ & 20 & $\%$ & 50 & $\%$ \\
\hline \multirow[t]{2}{*}{ *IfZ } & $\begin{array}{l}7 \sqrt{2} \\
f_{6}\end{array}$ & $\begin{array}{l}18 \\
14\end{array}$ & & $\begin{array}{l}15 \\
14\end{array}$ & $\begin{array}{l}75,0 \pm 969 \\
700 \pm 1225\end{array}$ & 23 & $\begin{array}{l}640 \pm 470 \\
560=702\end{array}$ \\
\hline & 牙 & 32 & $523 \pm 644$ & 29 & $225 \div 7$ & 61 & $610+428$ \\
\hline \multirow[t]{2}{*}{ 才和 } & $\begin{array}{l}\mathbf{2} \\
5\end{array}$ & 11 & & 5 & & $\begin{array}{l}16 \\
21\end{array}$ & \\
\hline & 牙 & 26 & $413 \times 640$ & 11 & $225 \pm 706$ & 37 & $370 \div 423$ \\
\hline \multirow[t]{2}{*}{$x \pi z$} & $\sqrt{\sqrt{2}}$ & & $\begin{array}{l}33 \pm 226 \\
23 \pm 326\end{array}$ & $\begin{array}{l}0 \\
0\end{array}$ & & & $\begin{array}{l}20 \pm 148 \\
20 \pm 198\end{array}$ \\
\hline & & 2 & $33 \pm 2.31$ & 0 & & & $20 \div 140$ \\
\hline
\end{tabular}

即ち男女共第 I 型の堠頭室宣が水平で声帯とダ上面上 同一平面上にあるものが過半数を占め，第】型がこれに 次き，声带より下外方に傾斜した第四型は男性に左右 各を1例宛見られたのみある。

更に喉頭室宣傾斜型の左右を比較すると，表6に示す よ5K，男女共左右同型のものが断然多く，左右不同型 のものは男性6例 (20.0\%)，女性 3例 (15.0\%) に認如 られたのみである。

表 6 喉頭空底倾斜龙右比諿

\begin{tabular}{|c|c|c|c|c|c|c|c|c|}
\hline \multirow{2}{*}{ 然 } & \multicolumn{2}{|c|}{ 倒 剿 } & \multicolumn{2}{|r|}{ 疋 } & \multicolumn{2}{|r|}{ 우 } & \multicolumn{2}{|r|}{ 古+氒 } \\
\hline & $\sqrt{2}$ & to & 30 & $\%$ & 20 & $\%$ & 50 & 4 \\
\hline \multirow{4}{*}{$\begin{array}{l}\text { 埾 } \\
\text { 点 } \\
\text { 点 }\end{array}$} & 武工 & 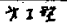 & 13 & $4.13 \pm 9.04$ & 13 & $6500 \pm 10$ & 26 & $520 \div 206$ \\
\hline & $\lambda \mathbb{2}$ & $\pi \pm$ 正 & 10 & $32.3 \pm \pm 60$ & 4 & $20.0 t$ & 14 & $22.0 \pm 6.35$ \\
\hline & $\pi 0$ & *正整 & 1 & $3.3 \pm 3.26$ & 0 & & , & $20 \pm 198$ \\
\hline & 5 & & 24 & $80,0 \pm 730$ & 7 & $86,0+7.97$ & $4 \pi$ & $820 \pm 543$ \\
\hline \multirow{2}{*}{$\begin{array}{l}\text { 甭 } \\
\text { ? }\end{array}$} & 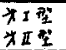 & 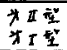 & & $\begin{array}{r}167 \pm 2.15 \\
23 \pm 3.26\end{array}$ & & $\begin{array}{r}10.0+6.71 \\
60+488\end{array}$ & $\begin{array}{l}7 \\
2\end{array}$ & $\begin{array}{r}140 \pm 491 \\
40 \pm 277\end{array}$ \\
\hline & & & 6 & $20,0+730$ & 3 & $15,0 \pm 799$ & 9 & $\left(\frac{180}{5}+5\right)$ \\
\hline
\end{tabular}

5. 喉頭小囊について

1)左右比較

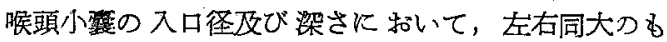
の，右側の大なるもの，左側の大なるものに分類する と，袁7に示すように，大口径及び梁さ共に男女を通じ て特別の差異を認めないが，只梁さにおいて女性は大側 に大なるものがや」少ない(10\%)のが目立つている・

表 7 喉頭小蹨左右比㙂

\begin{tabular}{|c|c|c|c|c|c|}
\hline \multirow{2}{*}{\multicolumn{2}{|c|}{$A_{t_{2} t_{0} n^{2}} \frac{10}{00}$}} & \multicolumn{2}{|r|}{$\lambda D X x^{2}$} & \multicolumn{2}{|r|}{ 理 } \\
\hline & & $n$ & $\%$ & $M$ & $\%$ \\
\hline \multirow{3}{*}{$\hat{0}$} & 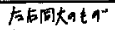 & 9 & $30.0 \pm 5.37$ & $x$ & $246 \pm 207$ \\
\hline & 古借大n 19 & 12 & $40.0 \pm 294$ & 9 & $30.0 \times 3.37$ \\
\hline & 左倒大at9 & 9 & $30,0 \div 8.37$ & 13 & $43.3 \div 9.04$ \\
\hline \multirow{3}{*}{ q9 } & 左古同大a的 & 5 & $25.0 \pm 469$ & $x$ & $40.0 \leq 10.95$ \\
\hline & fidaxata & 7 & $35.0=10.68$ & 10 & $500 \mathrm{R} / 11 / 8$ \\
\hline & 左例大at五 & 8 & 40.0 trags & $z$ & $10.0+6.71$ \\
\hline
\end{tabular}

2）入口径と室闻長との比較

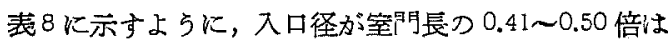
当るものが，男性では $35.0 \% \pm 6.19 \%$ ，女性では $30.0 \%$ 
$\pm 7.25 \%$ で，男女共 $0.31 \sim 0,60$ 倍の所謂入口径が荎門長 の $1 / 2$ 前後に相当するすのが過半数を占めており，しか あ左右側別的には殆んど出現率に差異を認めない。

表 8 矮頭小暴入径と室門長との比軷

\begin{tabular}{|c|c|c|c|c|c|c|c|}
\hline \multirow{2}{*}{\multicolumn{2}{|c|}{ 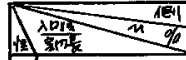 }} & \multicolumn{2}{|c|}{ 后 㰾 } & \multicolumn{2}{|c|}{ 古 例 } & \multicolumn{2}{|r|}{ 部 } \\
\hline & & $n$ & $\%$ & $n$ & $\%$ & $n$ & $\%$ \\
\hline \multirow{7}{*}{ o } & 付 $0 \sim 0.20$ & 1 & $3,3 \pm 3,26$ & 1 & $3.3 \pm 3.26$ & $z$ & $3.3 \pm 2.31$ \\
\hline & 0.2100 .30 & $4^{*}$ & $13.3 \pm 9.04$ & 3 & $100+5,4 x$ & 7 & $11.7 \pm 41 / 5$ \\
\hline & $0.31 \sim 0.40$ & 5 & $147 \pm 2.15$ & 4 & $133+9.04$ & 9 & $15,0=460$ \\
\hline & $0.41 \sim 0.50$ & 11 & $347 \pm 8.20$ & 10 & $323=\overline{8} 60$ & 21 & $35.0 \pm 6.16$ \\
\hline & $0.51-0.60$ & 3 & $t 5.48$ & 6 & $200=2.30$ & 9 & $150 \pm 4.60$ \\
\hline & $0.61-0.70$ & 4 & $13.3 \pm 4.04$ & 4 & $133 \pm 904$ & 8 & $123+438$ \\
\hline & $071 \sim 0.80$ & 2 & $0.7 \pm 456$ & $z$ & $47 \pm 456$ & 4 & $67 \pm 323$ \\
\hline & 1 $0=0.20$ & 0 & & ' & $5.0=4.88$ & 1 & $2.5 \pm 2.47$ \\
\hline & $0.21 \sim 0,30$ & 2. & $10.0 \pm 0.71$ & 1 & $50 \cdot 428$ & 3 & $75 \pm 416$ \\
\hline & $a_{3} / \sim 0.40$ & 5 & 25.05469 & 5 & $25.0=469$ & 10 & $250 \div k^{25}$ \\
\hline & $0.41 \sim 0.50$ & 8 & $40.0 \pm 1095$ & 4 & $200 \div 8.94$ & 12 & $300 \pm 725$ \\
\hline & $0.51-0.60$ & 2 & $10.0 \pm 6.71$ & 5 & $25: 0 \pm 901$ & 7 & $125 \div 401$ \\
\hline & $1-0.70$ & $z$ & $10.0 \pm 671$ & 3 & $15.0 \pm 299$ & 5 & $12.5 \pm 5.23$ \\
\hline & & 1 & $5,0 \pm 4,88$ & 1 & $50+488$ & $z$ & $5,0 * 3.45$ \\
\hline
\end{tabular}

3) 入口の位置

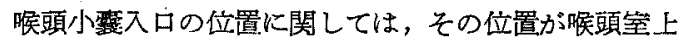
壁の前部にあるもの，中央にあるもの，文入口が広く喉 頭上壁の大部分を占める所謂広口型のものもあり，これ 等は分類すると, 表9に示すように，中部にあるすのが 過半数 $(62.0 \%)$ を占め, 次いで広口型の $32.0 \%$, 前部 及び後部に存在するすのは僅かで，男女共㬋頭室上壁の 中部にあるものが多く，中でも女性は77.5\%とその殆 んどを占めている・

表 9 喉頭小独入口の位圆

\begin{tabular}{|c|c|c|c|c|c|c|}
\hline $77^{4}$ & \multicolumn{2}{|r|}{5} & \multicolumn{2}{|r|}{ F } & \multicolumn{2}{|c|}{ s+9 } \\
\hline$(120)$ & $n$ & $\%$ & $n$ & 6 & $n$ & $\mathscr{6}$ \\
\hline 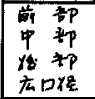 & $\begin{array}{r}4 \\
31 \\
24\end{array}$ & $\begin{array}{r}0.7+3.23 \\
51.7+6.45 \\
67 \pm 167 \\
400 \pm 403\end{array}$ & $\begin{array}{l}1 \\
31 \\
0 \\
8\end{array}$ & $\begin{array}{r}2.5 \pm 247 \\
775 \pm 660 \\
200 \pm 633\end{array}$ & $\begin{array}{r}5 \\
62 \\
1 \\
32\end{array}$ & $\begin{array}{r}50 \pm 218 \\
620 \neq 486 \\
10: 2115 \\
320: 467\end{array}$ \\
\hline
\end{tabular}

比輘：以上は筆者の九州日本人に括ける成續である が，これを先人の成績と比較すると，次の如くである。

1. 堠頭口 (表 10)

1) 矢状径: 男性は平均 $29.9 \mathrm{~mm}$ で日本人 (松島)と 殆んど大差なく，女性は平均 $23.5 \mathrm{~mm}$ で日本人(松島) よりや」小さい。

表 10 喉頭口仅び声阴下腔比較（单位mm）

\begin{tabular}{|c|c|c|c|c|c|c|c|c|c|c|c|}
\hline \multirow{2}{*}{$\frac{15}{2}$} & \multirow{2}{*}{ 人䄈 } & \multirow{2}{*}{ bots } & \multirow{2}{*}{ 諸㛬 } & \multicolumn{4}{|c|}{ 5 } & \multicolumn{4}{|c|}{ q } \\
\hline & & & & $n$ & $M \pm m$ & max. & min. & $n$ & $M \neq m$ & mes. & $\min$ \\
\hline \multirow{3}{*}{$\begin{array}{l}\text { 信 } \\
\text { D. } \\
\text { D }\end{array}$} & 九州旧本人 & 增山 & 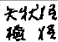 & 30 & & $\begin{array}{l}350 \\
250\end{array}$ & $\begin{array}{r}23,0 \\
20\end{array}$ & $\begin{array}{l}20 \\
20\end{array}$ & & 340 & 11.0 \\
\hline & & & 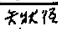 & 87 & $>1.7 \pm 0.71$ & 440 & 210 & 33 & $29.0 * 0.72$ & 320 & 20,0 \\
\hline & & 745 & & 57 & $17.0 \div 0.40$ & 2510 & 10.0 & 33 & $140=0.30$ & $1 \times 0$ & 10.0 \\
\hline \multirow{3}{*}{$\begin{array}{l}\text { 点 } \\
\text { 挭 } \\
\end{array}$} & 九州本人 & th & 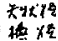 & $\begin{array}{l}30 \\
30\end{array}$ & $\begin{array}{l}146 \leq 0.29 \\
145+242\end{array}$ & $\begin{array}{l}18.0 \\
210\end{array}$ & $\begin{array}{l}10.0 \\
120\end{array}$ & $\begin{array}{l}20 \\
20\end{array}$ & $119 \pm 0.34$ & $\begin{array}{l}14.0 \\
120\end{array}$ & $\begin{array}{l}80 \\
110\end{array}$ \\
\hline & & 12 部 & $512 \pi$ & 57 & $14.3 * 0.19$ & 170 & 110 & 23 & $(19+a) 2$ & 160 & 20 \\
\hline & $\theta A \lambda$ & | th का & 泡 & 57 & $1.8+0.50$ & 120 & 100 & 3.3 & $11.3=0.28$ & 15.0 & x.0 \\
\hline
\end{tabular}

2）横径：男性は平均 $17.8 \mathrm{~mm}$ で日本人（烃島）上殆 几ど類似し，女性は平均 $13.8 \mathrm{~mm}$ でこれも男性同㴍日 本人（松島）と殆んど一致している.

更に性別的には松島の日本人及び筆者の九州日本人共 に男性が女性より優つている。

2. 声門下腔 (表 10)

1）矢状径：男性は平均 $14.6 \mathrm{~mm}$ で，日本人 (松島) と殆んぞ一致し，女性は平均 $11.9 \mathrm{~mm}$ で日本人（松島） と全く一致している。

2）横径：男性は平均 $16.5 \mathrm{~mm}$ で，日本人(松島)よ りゃ」大である・

即ら声門下腔における矢状径と横径は，九州日本人で は後者がや大で，形態は前後に圧迫された棈円形を呈 しているのに反し，日本人（松島）では前者が男性では や」大，女性では殆んど差を諗めないが，僅かに大で， 九州日本人に较べて声門下腔の形態はや」左右に匠迫さ れた棈円形を呈している・但し松島の場合は病理解剖屍 体より得たるのである。

更に性別では筆者の九州日本人，松島の日本人共に男 性が女性より勝れている。

3. 喉頭蓋軟骨形態と喉頭口及び声門下腔との関係 前述の㬋頭蓋軟骨形態により分類し，喉頭口及び声門， 下腔の大きさを観察すると，㬋頭口では表11に示すよ 弓に，男性では九州日本人，日本人（松島）共に矢状径 横径に括いて a, b, c, d (e 型を両者共除けば) の各型

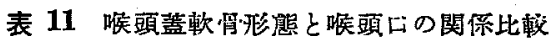
(単位 $\mathrm{mm}$ )

\begin{tabular}{|c|c|c|c|c|c|c|c|}
\hline \multirow{3}{*}{\multicolumn{2}{|c|}{+2}} & \multicolumn{3}{|c|}{ 几州日本人（鉍山） } & \multicolumn{3}{|c|}{ 日本人 (秘禹) } \\
\hline & & \multirow{2}{*}{$n$} & $x \times x \times \frac{z}{2}$ & $f x^{2}$ & \multirow{2}{*}{$m$} & 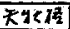 & 称1/2 \\
\hline & & & $M \pm m$ & $M \pm m$ & & $M$ & $M$ \\
\hline \multirow{5}{*}{$\hat{\gamma}$} & a & 20 & $30.4 \pm 092$ & $18.6 \pm 0.72$ & 32 & 326 & 173 \\
\hline & \& & 5 & $29.2 \pm 0.91$ & $18.0 \pm 1.23$ & 10 & 319 & 171 \\
\hline & c & $z$ & $28.0 \pm 254$ & $170 \pm 3.54$ & $\mathbb{8}$ & 316 & 16.6 \\
\hline & $d$ & 2 & $270 \div 0.71$ & $155+0.35$ & 5 & 26,6 & 14.0 \\
\hline & $\ell$ & 1 & 320 & 70 & 2 & 320 & 19.0 \\
\hline \multirow{4}{*}{. } & $a$ & 10 & $248 \pm 1.61$ & $147 \pm 0.68$ & 24 & 29.2 & 145 \\
\hline & $\ell$ & 7 & $21.1 \pm 675$ & $141 \pm 0.79$ & $z$ & 275 . & 130 \\
\hline & c & 1 & 260 & 5,0 & 7 & 26.9 & 12.6 \\
\hline & $\begin{array}{l}\alpha \\
e\end{array}$ & $\begin{array}{l}z \\
0\end{array}$ & $19.0 \pm 0.00$ & $125 \div 1.77$ & $\begin{array}{l}0 \\
0\end{array}$ & & . \\
\hline
\end{tabular}

の順序に大きく，女性では矢状径，横径共に九州目 本人に赫いて $\mathrm{a}, \mathrm{b}, \mathrm{d}$ (c 型型を除く) の順に，日 本人 (松島) では a, $\mathrm{k}, \mathrm{c}$ 型の䐣に夫々大きく，両 者共殆んど一致している。

又声門下腔に括いては表 12 に示すように日本人 （松島）の男性では㜊頭口と同様知状经，横径共に 
その広さは凡之 $a, b, c, d$ 型の順序を示し，九州日本 人男性と同じく女性の矢状经及び日本人（烃島）女性で

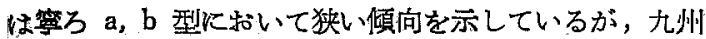
日本人の横径は判然たる順序を示さない。

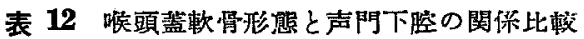
(算位 $\mathrm{mm}$ )

\begin{tabular}{|c|c|c|c|c|c|c|c|}
\hline \multirow{3}{*}{\multicolumn{2}{|c|}{ 性 7}} & \multicolumn{2}{|r|}{ 九十曰A人 } & (增山) & \multicolumn{3}{|c|}{ 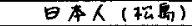 } \\
\hline & & \multirow{2}{*}{$n$} & 先妆得 & 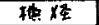 & \multirow{2}{*}{$n$} & 知技䭪 & 榙烧 \\
\hline & & & $M \pm m$ & $M \pm m$ & & $M$ & $M$ \\
\hline \multirow{5}{*}{8} & $a$ & 20 & $14.4 \pm 0.54$ & $16.3 \pm 0.47$. & 32 & 14.6 & 14.2 \\
\hline & 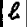 & 5 & $144 \pm a 36$ & $10.4 \mathrm{t} / 2 \pi$ & 10 & 14.3 & 139 \\
\hline & $c$ & $\mathbf{z}$ & $15.0 \pm 0.00$ & 19001.80 & 8 & 13.6 & 13.0 \\
\hline & $d$ & $z$ & $10.5 \pm 0.35$ & $10.5 \pm 0.35$ & 5 & is $x$ & 12.8 \\
\hline & $e$ & 1 & 170 & 120 & $z$ & 140 & 14.0 \\
\hline \multirow{4}{*}{\multicolumn{2}{|c|}{ 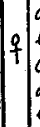 }} & 10 & $11.9 \pm 0.46$ & $13.5 \pm 0.51$ & 24 & 114 & 10.8 \\
\hline & & 7 & $11.4 \pm 0.75$ & $2.7 \pm 0.48$ & $\boldsymbol{z}$ & 10.5 & 9.0 \\
\hline & & 1 & 130 & 120 & 7 & 120 & 123 \\
\hline & $\begin{array}{l}a \\
e\end{array}$ & $\begin{array}{l}z \\
0\end{array}$ & $13.0 \pm 0.71$ & $1 \times 0 \pm 150$ & $\begin{array}{l}0 \\
0\end{array}$ & & \\
\hline
\end{tabular}

4. 声門裂及び前庭裂

表 13 亿示すように，声門裂では平均 $3.0 \mathrm{~mm}$, 前庭裂 では平均 $5.2 \mathrm{~mm}$ といずれも支那人より小さく，声門裂 においては，欧洲人は計測部位不明，又は披裂軟骨内縁 間距離及び声帯突起間距離と計測部位を異にするため比 較対照する事ができないが，いずれにせよ九州日本人は 他の人種に比し劣つているようである・

表 13 声門裂及び前庭裂比輘（単位 $\mathrm{mm}$ )

\begin{tabular}{|c|c|c|c|c|c|c|c|c|c|c|}
\hline \multirow{2}{*}{\multicolumn{2}{|c|}{ 人種 }} & \multirow{2}{*}{ 朝制有 } & & \multirow[b]{2}{*}{$x$} & \multicolumn{3}{|c|}{ 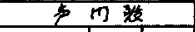 } & \multicolumn{3}{|c|}{ 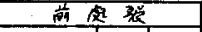 } \\
\hline & & & & & $M \pm m$ & mex. & $\min$. & $M \pm m$ & max. & min. \\
\hline \multicolumn{2}{|c|}{ 几Hl体K } & 譪山 & b & 30 & \multirow{2}{*}{$\begin{array}{l}3.8 \pm 0.22 \\
4.8 \pm 0.68\end{array}$} & 510 & 10 & $52 \pm 0,46$ & 11.0 & 1.0 \\
\hline \multicolumn{2}{|c|}{ 支那人 } & $1 / 24$ & +9 & 50 & & 10.0 & 20 & $8.7+0.52$ & 16.0 & 40 \\
\hline \multirow[t]{2}{*}{$\begin{array}{l}\text { 政 } \\
\text { 州 } \\
\text { 人 }\end{array}$} & \multirow{2}{*}{\multicolumn{2}{|c|}{$\begin{array}{l}\text { Sinchia } \\
\text { Frinkel } \\
\text { Merkel } \\
\text { Huschtes } \\
\text { Bungel } \\
\text { Semim } \\
\text { Feim }\end{array}$}} & $\begin{array}{l}1 \\
5 \\
5 \\
\Delta \\
\Delta\end{array}$ & & \multicolumn{3}{|c|}{$\begin{array}{l}50 \sim 6.0 \\
5.0 \sim 60\end{array}$} & \multicolumn{3}{|c|}{ 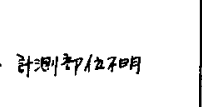 } \\
\hline & & & $\begin{array}{l}5 \\
5 \\
6 \\
6\end{array}$ & $!$ & $\begin{array}{l}43 \\
5.0 \\
3.4\end{array}$ & $\begin{array}{l}6.5 \\
6.0 \\
40\end{array}$ & $\begin{array}{c}0.5 \\
3.5 \\
0\end{array}$ & 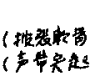 & & 距辣了 \\
\hline
\end{tabular}

表 14 声門裂対前庭裂の比比較

\begin{tabular}{|c|c|c|c|c|}
\hline $\mathrm{F}_{\mathrm{N}} \mathrm{k}$ 理 & & $H \theta \bar{A} \alpha\left(t^{2}\right)$ & & $P R\left(u\left(f_{2} \psi_{1}\right)\right.$ \\
\hline & & 古 & & 9 \\
\hline & 30 & $\%$ & 50 & $\not 6$ \\
\hline $0.9 \nu<T$ & $z$ & $6.7 \pm 4.44$ & 0 & \\
\hline 1.0 & 4 & $13.3 \pm 6.20$ & 0 & \\
\hline $1.1-1.5$ & 6 & $200 \pm x+90$ & 10 & $20.0 \pm 5.66$ \\
\hline $1.6 \sim 2.0$ & 11 & $367 \pm 2.20$ & 34 & $680+460$ \\
\hline $2.1-2.5$ & 4 & $13.3 \pm 6.20$ & 5 & $10.0 \div 424$ \\
\hline $2.6 \sim 3.0$ & & $3.3 \pm 3.26$ & 0 & \\
\hline $3.1 \sim 3.5$ & $z$ & $6.7 \pm 454$ & 1 & $20+198$ \\
\hline
\end{tabular}

更に声門裂々前庭裂の 比を比較して見ると，表 14 亿 示すように，1.6〜2.0 倍に相当するものが $36.7 \%$ と最も 多く，次いで 1.1〜1.5 倍の $20.0 \%$ となつて括り，支那 人に抹いても同様に $1.6 \sim 2.0$ 倍が $68.0 \%$ と過半数を 占 め, 次いで $1.1 〜 1.5$ 倍の $20.0 \%$ を示し，支删人に拈い
ては前庭裂が声門裂より小さいるのは 1 例わなく，九州 日本人に括いては同長 4 例，小さいもの 2 例に諗められ た・

\section{5. 声 带 長}

表 15 に示すように，男性は平均 $19.8 \mathrm{~mm}$ で，欧洲人 が最も大で支那人これ次ぎ，日本人（尾関，松島）及 び九州日本人が小さく，この中でる九州日本人が最す小 さい女性は平均 $15.3 \mathrm{~mm}$ で，尾関及び Schaffer， Symongton の欧洲人が最も大で，日本人（松島）より や小小く，日本人（尾㓵）とは殆んぞ類似している．

更に性別的にみると，すべての人種共男性が女性より も優って招り，九州日本人と一致している。

表 15 声帶長比較 (単位 $\mathrm{mm}$ )

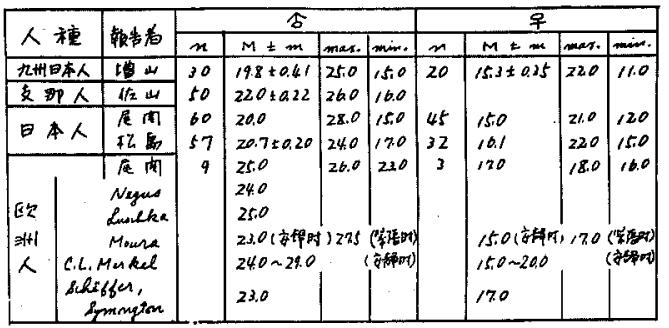

6.上甲状切痕底から室ヒが附着迫及び声帯附着点 迄の距離

表16 亿示寸ように，上甲状切痕底から室七ダ附着点 迄の距離は男性平均 $6.1 \mathrm{~mm}$ で，他人種と殆んど美異を 認めず，女性は平均 $3.9 \mathrm{~mm}$ で，欧洲人（尾関）が最す 大で，他は殆んぞ類似している・

表 16 上甲状切痕底より室七ダ附着点迄及び

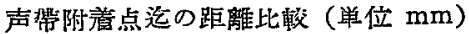

\begin{tabular}{|c|c|c|c|c|c|c|c|c|c|c|}
\hline \multirow[b]{2}{*}{ stol } & \multirow{2}{*}{ 人握 } & \multirow{2}{*}{ 赫告有 } & \multicolumn{4}{|c|}{ s } & \multicolumn{4}{|c|}{ 平 } \\
\hline & & & $m$ & $M \pm m$ & ment. & $\min$. & $m$ & $M \pm m$ & mex. & $\min$. \\
\hline \multirow{4}{*}{ 磅 } & $\begin{array}{l}n+10 \neq \alpha \\
\theta \neq \alpha\end{array}$ & $\begin{array}{l}t+4 \\
\text { Fin }\end{array}$ & 30 & $\begin{array}{l}6.1 \pm 0.38 \\
6.0\end{array}$ & 11.0 & 3.0 & 20 & $\begin{array}{l}3.9 \pm 0.20 \\
2.5\end{array}$ & 5,0 & 2.0 \\
\hline & & 6 古 & 60 & 6.0 & 10.0 & 3.0 & 45 & 35 & 10.0 & 20 \\
\hline & ש2 $3+4 \alpha$ & $\Leftrightarrow 0$ & 29 & 6.0 & & & 29 & 40 & & \\
\hline &. & & 9 & 60 & 100 & 5.0 & 3 & 5.5 & 40 & 5.0 \\
\hline \multirow{3}{*}{ 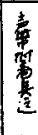 } & 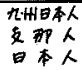 & 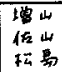 & $\begin{array}{l}30 \\
50\end{array}$ & $\begin{array}{l}8.1 \pm 0.37 \\
8.7 \pm 0.21 \\
10.0\end{array}$ & $\begin{array}{l}120 \\
12.0\end{array}$ & $\begin{array}{l}50 \\
20\end{array}$ & 20 & $\begin{array}{l}54 \pm 0.23 \\
70\end{array}$ & 7.0 & 3.0 \\
\hline & $\cdot$ & A & 60 & 100 & 14.0 & 60 & 45 & 20 & 9.0 & 5.0 \\
\hline & Ez & 田早古 & 29 & $\begin{array}{l}8.5 \\
115\end{array}$ & & 9.0 & 24 & $\begin{array}{l}45 \\
2.5\end{array}$ & 9.0 & 80 \\
\hline
\end{tabular}

又上甲状切痕底 $8.1 \mathrm{~mm}$ で，支那人，日本人（尾関，松島），欧洲人之比 ベて最す小さい女女性は平均 $5.4 \mathrm{~mm}$ で，男性と同栐他 の人種に比し最も小さい。

7. 㟮 頭 窒

1）喉頭室\&門諸径（表 17） 


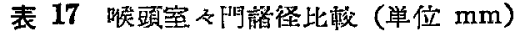

\begin{tabular}{|c|c|c|c|c|c|c|c|c|c|c|}
\hline \multirow{2}{*}{$\begin{array}{ll}16 \\
12\end{array}$} & \multirow{2}{*}{ 人㭫 } & \multirow{2}{*}{ 敖吉者 } & \multicolumn{4}{|c|}{5} & \multicolumn{4}{|c|}{ 우 } \\
\hline & & & $n$ & $M \pm m$ & mex & mam & $n$ & $M \pm m$ & max. & $\min$ \\
\hline \multirow{3}{*}{$\mid \begin{array}{l}\text { E } \\
\pm\end{array}$} & 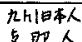 & 均山 & $\begin{array}{l}30 \\
50\end{array}$ & $152 \pm 031$ & 200 & 120 & 20 & $110 \pm 012$ & 180 & 50 \\
\hline & 白木 & 八木:尺 & & & 200 & 160 & & & 150 & 110 \\
\hline & & 尾同 & & 120 & & & & 130 & & \\
\hline \multirow[b]{2}{*}{ 中 } & 几明日人 & 士熼山 & 30 & $33 \pm 025$ & 80 & 10 & 20 & $/ 8 \pm R / 7$ & 70 & 10 \\
\hline & 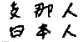 & 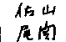 & 50 & $\begin{array}{l}4.5 \pm 013 \\
2.5\end{array}$ & 70 & 2.0 & & & & \\
\hline \multirow{3}{*}{$\left(\begin{array}{c}5 \\
5\end{array}\right.$} & 九州輣人 & 增山 & 30 & $46 \pm 016$ & 80 & 20 & 20 & $3.1 \pm 0.13$ & 40 & 2.0 \\
\hline & 支 $\pi$ & $1 \sqrt{2}$ & 50 & $43 \pm 0 / 8$ & 80 & 10 & & & & \\
\hline & 日本人 & A末x & & & 100 & 60 & & & 100 & 40 \\
\hline
\end{tabular}

1）長さ：男性は平均 $15.2 \mathrm{~mm}$ て, 日本人(尾関) が 最も大て，支那人これに次ぎ，九临日本人が最も小さ い.女性は平均 $11.0 \mathrm{~mm}$ て日本人（尾関）より小であ る.

11）幅 男性は平均 $3.3 \mathrm{~mm}$ て支那人上り小，日本人 (尾関)より大てある.

1ii）潹さ. 男性は平均 $4.6 \mathrm{~mm}$ て, 日本人(尾関) よ り小て，支那人よりや」大てある。

2）㬋頭室々門側別（表 18）

以上の長さ，幅，梁さにおいて，更にこれを左右別に 観察すると，三者共に右側の大なるるのが夫ふ多く，次 いて左右同大のもの，左側の大なるるのは最も少なく， 支那人ては長さ，幅に和いて約半数文はそれ以上左右同 大のものが占め，深さに和いては左右同大のるのと右側 の大なるものが $38.0 \%$ 同率てあるが，左右不均等の 例のらち過半数は右側が大て，これ等は九州日本人の埸 合と全く一致している.

表 18 喉頭堂\&門側別比酷

\begin{tabular}{|c|c|c|c|c|c|c|c|c|c|}
\hline \multirow{2}{*}{ 福 } & \multirow{2}{*}{ 整 } & & \multirow{2}{*}{ 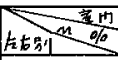 } & \multicolumn{2}{|c|}{ E } & \multicolumn{2}{|r|}{ p } & \multicolumn{2}{|r|}{ 棌 } \\
\hline & & & & $m$ & $\%$ & $x$ & $\%$ & $n$ & $\%$ \\
\hline 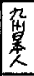 & 垉 & 5 & 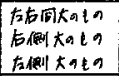 & $\begin{array}{r}10 \\
14 \\
6\end{array}$ & & $\begin{array}{c}9 \\
15 \\
6\end{array}$ & & $\begin{array}{c}7 \\
77 \\
5\end{array}$ & \\
\hline 考 & 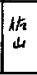 & 16 & 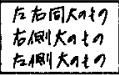 & $\begin{array}{r}30 \\
13 \\
7\end{array}$ & $\begin{array}{l}600+693 \\
260+021 \\
140+441\end{array}$ & $\begin{array}{l}26 \\
16 \\
8\end{array}$ & $\begin{array}{l}520 \pm 706 \\
320 \pm 6.60 \\
160 \times 519\end{array}$ & $\begin{array}{l}19 \\
19 \\
12\end{array}$ & $\begin{array}{l}320 \pm 626 \\
370 \pm 626 \\
240 \div 604\end{array}$ \\
\hline
\end{tabular}

3) 唉頭窒底傾斜

前述の 3 型に分類すると，表 19 に示すように，筆者 の調查した九州日本人喉頭に和いては第 I 型最も多く，

表 19 踇頭室底傾斜比杴

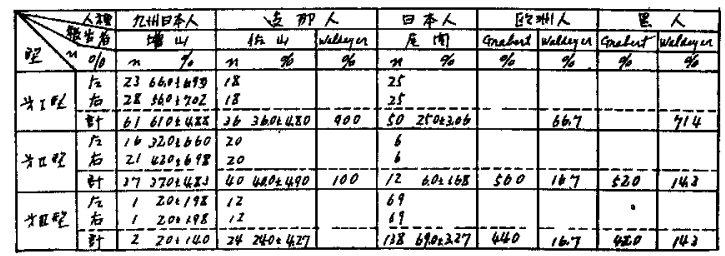

第】型これに次ぎ，第向型は最る少ないが，尾関の謂查 した日本人ては全例の 69.0\%が第四型で，第Ｉ整は $25.0 \%$ ，第 II 型は6.0\% に過ざず，更に支那人，欧洲人 及び黒人に特ける諸家の政告を見ると，その成續は一致 せず，同一人瑀文は相近似した人種に和いてるこのう に成績が異なるのは，観察基集の相違に依るるのと思わ れる・故にこれ等の成續より直らに人種的特徽を云々す るのは变当てない.

次に左右別を調查すると，表 20 に示すよらに，80,0 \%は左右同型で，卖那人の $92.0 \%$ に比しや〉务つてい るが殆えどその趣を一つにしている。

表 20 㗛頭室底傾斜側別比較

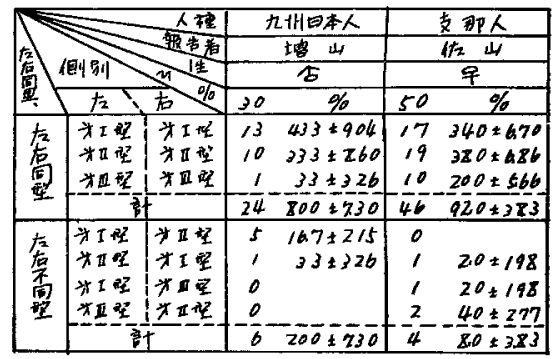

8. 㬋頭小琶视

1) 喉頭小褧諸柽 (表 21)

1）入口径：男性は平均 $7.0 \mathrm{~mm}$ て, 支那人之殆んと 類似している.

11）樑さ：男性は平均 $5 \mathrm{lmma}$ て, 支那人上り小で ある・

表 21 喉頭小彁諾径比較

\begin{tabular}{|c|c|c|c|c|c|c|c|}
\hline 被狌 & 人枉 & 得告居 & 性 & $m$ & $M \pm m$ & $\operatorname{mex}$ & $\operatorname{man}$. \\
\hline 金 & 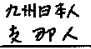 & $\begin{array}{l}\text { 坡山 } \\
\text { 你山 }\end{array}$ & 5 & $\begin{array}{l}50 \\
50\end{array}$ & $\begin{array}{l}30 \pm 027 \\
66 \pm 027\end{array}$ & $\begin{array}{r}120 \\
140 \\
\end{array}$ & $\begin{array}{l}20 \\
20\end{array}$ \\
\hline 采 & 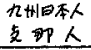 & $\begin{array}{l}\text { 嘈山 } \\
\text { 你山 }\end{array}$ & 古 & $\begin{array}{l}30 \\
50\end{array}$ & $\begin{array}{l}51 \pm 0.38 \\
68 \pm 0.20\end{array}$ & $\begin{array}{l}140 \\
23.0 \\
\end{array}$ & $\begin{array}{l}20 \\
20\end{array}$ \\
\hline
\end{tabular}

2) 側別 (表 22)

以上の入口径及び梁さに扣いて，更に左右を比較する と，梁さに和いて左側大なるあのがや〉多い外は著しい 左右別を認めない，支那人の場合と殆んど類似してい 石.

表 22 喉頭小露臂径側別比較

\begin{tabular}{|c|c|c|c|c|c|c|c|}
\hline 人 & 劸 & 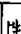 & 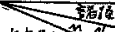 & & 入口㹩 & & 茨 \\
\hline & & 17 & 江吉别 & $n$ & $\%$ & $n$ & $\%$ \\
\hline 在 & t为 & & 右成大のセの & 9 & $300 \pm 237$ & $\bar{x}$ & $2 b, b \pm 207$ \\
\hline 基 & 4 & $\delta$ & 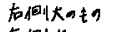 & 12 & $400 \pm 294$ & 9 & $300 \pm 737$ \\
\hline & & & F柦は大のもの & 9 & $300 \pm 837$ & 13 & $4 \times 3+904$ \\
\hline 夌 & d/a & $\pi$ & 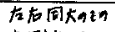 & 17 & $340 \pm 470$ & & 260 \\
\hline 然 & 4 & 6 & 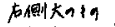 & 16 & $320 \pm 6.60$ & & 320 \\
\hline & & & 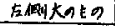 & 17 & $340+670$ & & 240 \\
\hline
\end{tabular}


3) 㬋頭小主入日径亡腒頭室\&門長の比輘 (表 23)

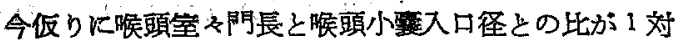
0.61 上上の るのを広口型と守れば，その出現は12 例 (20.0\%) で，その殆えどは狭口型に属し，支那人の場 合本広口型は 8 例 $(8.0 \%)$ に過きす，大半恃㹟口型で雨 者殆えど一致している。

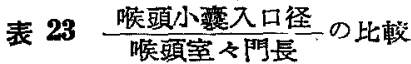

\begin{tabular}{|c|c|c|c|c|c|c|c|c|}
\hline & & & & F. A例 & & 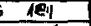 & & Et \\
\hline & & 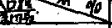 & $m$. & $\%$ & $m$ & 4 & $x$ & 46 \\
\hline & & $1>0 \sim 220$ & & $23 \pm 3.26$ & & $23 \pm 2.2 b$ & $z$, & $3.3 \pm 2.31$ \\
\hline & & $0,21-0,30$ & .4 & $123 \pm 204$ & 3 & $100 \pm 548$ & 7 & $11.7 \div 4.15$ \\
\hline カH怕た人 & $\delta$ & $0.31-240$ & 5 & $167 \pm 2,15$ & 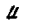 & $123 \pm 814$ & 9 & $1500 \pm 460$ \\
\hline & & $0.41-0.50$ & 11 & $367 \pm \times 10$ & 10 & $223=860$ & $2 I$ & $350 \pm 6.16$ \\
\hline & & $0.1 / 20.60$ & & $100 \pm 543$ & 6 & $20.0 \pm 230$ & 9 & $150^{\circ}+460$ \\
\hline (始山) & & $0.61-0.70$ & 4 & $13.3 \pm 804$ & 4 & $13.3 \div 2.04$ & $x$ & $133 \pm 43 x$ \\
\hline & & $0.71-0.80$ & $z$ & $67 \div 456$ & $z$ & $67 \pm 456$ & 4 & $6.7 \pm 3.23$ \\
\hline & & lit $0-420$ & & $20 \div 3.23$ & 5 & $120 \pm 424$ & 9 & $90 \pm 2 . x 6$ \\
\hline & & $a 21-0.30$ & 14 & $280 \pm 6.25$ & 9 & $120 \pm 1: 63$ & 23 & $230 \pm 421$ \\
\hline 支显人 & 今5 & $031 \sim 0.40$ & 14 & 280.435 & 16 & $320 \pm 660$ & 30 & $30.0 \pm 3.87$ \\
\hline & & $0.41 \sim 0.50$ & 11 & $226 \pm 5 x 6$ & 10 & $20.9 \pm 5.66$ & 21 & $28.0 \pm 407$ \\
\hline & & $0.51-0.60$ & 4 & $2.0 \pm 2.23$ & 5 & $100+424$ & 9 & $90 \pm 2.15$ \\
\hline$(/ / 2 \omega)$ & & $0,61 \sim a 70$ & & $20 \div 1.92$ & 4 & $20 \pm 3,23$ & 5 & $5.0 \pm 6.89$ \\
\hline & & $0.71-0.80$ & & $20 \div 1.98$ & 0 & & 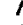 & 1.0 .3 .15 \\
\hline & & $021 \sim 090$ & 0 & & 1 & $20 \pm 198$ & 1 & $20=315$ \\
\hline & & & $f$ & $20 \times 1.98$ & $\theta$ & & & $20 \pm 1 / 15$ \\
\hline
\end{tabular}

4）入口の位置 (表 24)

広口径を゙呈するるのは日本人 (尾関)が最高位を占め， 次いで黒人，欧洲人，九州日本人の順となり，支那人は 最も頻度が少ない..气の他の狭口型に関しては黒人，欧 洲人に拉いては前部に存するものが多く，日本人(星関) に颃いては後部存在するのに反し，九州日本人，支那 人においては半数文は過半数は中部に存在し, 後部に存 在するるのは雨者共著しく少なく，ス口の位置に関して は九州日本人と支䛍人は殆んど類似している・

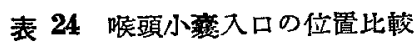

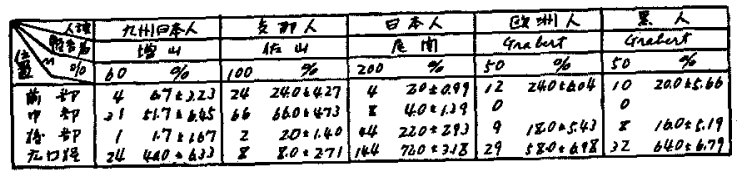

5）破格

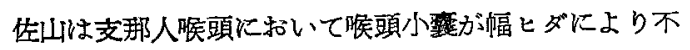
完全に二室に分劃されたすの4例及び完全に二空に分れ たもの2例，その他非常に梁長なもの1例及び痕跡のみ に止るもの1例等を認めているか゚，筆者の調查例では異 常乃至破格は 1 例む認められなかつた・

\section{III. 総括並ひに結論}

九州出身の成人喉頭男 30 例，女 20 例，計 50 例の侯 頭腔所見に就いて調查し，男女比較及び支那人，欧那 人，他地方出身の日本人の成績と比較した・
1. 䐅頭腙各部の大きさ忖すべて女性よりる男性に優 つて和り・喉頭蓋軟骨の形態亡㬋頭口及び声門下膑, 特 に㬋頭口の大きさとの関娇では，男女共 a 型が最む大 で，b 型がこれに㳄ぎ， $d$ 型が最も小である。

声門裂は前庭裂上り狭くその半分垱当るるのが最も多

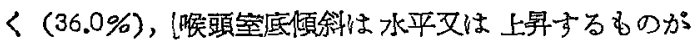
多く，下降するるのは甚だ少ない，更に喉頭小整入口の 位㯰は㬋頭室上壁の中央にあるるのが最も多い(62.0 $\%$ ).

2. 九州日本人唉頭㬵各部の大きさは，男女共一般に 欧洲人の夫れより小で，他地方出身の日本人とは殆んど 類似しているが，男性に拈いては支那人の夫机よりや〉 小である・性別的に性欧洲人，他地方出身日本人，九州 日本人共に男性が女性より侵つている・

3. 䐅頭小西入口の位固は，黒人，欧洲人にては前部 に，日本人 (尾関) では後部に存在するのに反し，九州 日本人，支那人に怙いては半数又は過半数は中部に存在 し，後部に存在するるのは両者最す少ない:

\section{文: 献}

1) Chievitz, J.H.: Untersuchung über die Verknocherung der menschtichen Kehlkopf, Arch. $f$. Anat. u. Physiol. (Anat. Abt.), 303, 1882.

2) Müller: Beit rage zur Kennthis der Kehlkopfmuskulatur, Arch. f. . Laryng. u. Rhinolog., 12；162,1902. 3) 中山末堆: 日本人の喉頭軟营 片いかに化骨するか，耳學咽喉科京都臨床，2，1908. 4) Adachi: Beiträge zur Anatomie der Japaner. Statistik der Muskelvarietäten, Zeitsch. f. Morphol. u. Anthropol., 12；261，1910. 5) 尾関才吉：本 邦人短頭の局所㐿剖学上の補遗，東京医会誌， 27 (17)，752，1911. 6）尾闑才吉：本邦人の甲状軟 霄，東京医会誌，25(21)，969，1911。7) 尾関才 吉：本邦人の輸状軟管，東京医会誌，26(15), 919,1912. 8) 尾関才吉：日本人の輪状甲状筋, 東京 医会誌, $27(7), 411,1913.9$ 9) Grabert. W.: Anthropologische Untersuchungen an Herero-und Hottentottenkehlköpfen, Zeitschr. f. Morphol. u. Anthropol., 16；65，1914. 10）八杖交吾：本邦人の

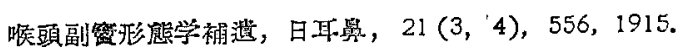

11) Kurz. E.: Untersuchungen über Grössen-und. Formhältnisse des Zungenbeines und des Kehlkopfskelettes einer 25 jährigen Chinesin, Arch, $f$. 
Anat. u. Physiol. (Anat. Abt.), 216, 1918. 12) Eckert-Möbius: Enchondrale Verknöcherungen und Knorpelgefässsystem mit besonderer Berscksichtigung des menschlichen Felsenbeins. Arch. f. OhrenNasen-Kehlkopf H., III, 155, 2924.

13) CurtElleRostock: Denker u. Kahler's Handbuch der HalsNasen-Ohren Heilk., 1; 225, 1925. 14) Waldeyer: $\mathrm{Z}_{\mathrm{vr}}$ Individual u. Rassenatomie des menschlichen Kehlkopfes, Zeitschr. f. Morphol. u. Anthropol., 24，1926.15）保利清：本邦人の喉頭軟学化骨に関す るレントゲン学的研究, 日本レントゲン学会誋，5(1)， 1，1927，16）方岡照夫：喉頭軟骨再生に関する実呀 的研究，京都府大雑誌，2(3)，931，1928，17) 传山光 章：朝鮮人に䑙ける後輸状披裂筑の破格について，渵

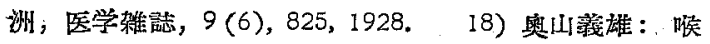

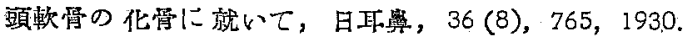
19）三上紀之：日本人喉頭顿骨化骨に関する僻部学的 研究，解剖学雜諗，3(5),647, 1930. 20) 佐山光龺：

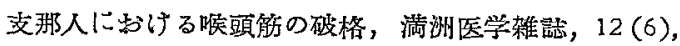
769，1930. 21）佐山光章：支那人喉頭软骨の化骨に 就いて, 渶洲医学雑誈, $14(6), 271,1930.22)$ 佐山洸 章：支那人㱩頭の研究 (1), 満洲医学雑誌, 15(6), 665，1931. 23）佐山洸音：支那人の甲状披裂䈈に就

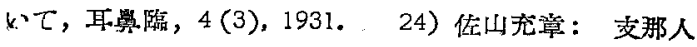
啹頭の研究 (2), 泗测医学雄誌, 16 (1),.59, 1932. 25) 佐山充章：支那人喉頭の研究 (3), 満洲医学雑誌, 16
(4)，551，1932. 26）杂屾芳郎：台湾藩人の Vallecula epiglottica, 台滦医学雑钴, 33 (3), 474, 1934.27) 北

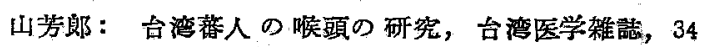
(9)，1349，1935. 28）湯浅充雄：生体にお゙ける正常知 頭軟骨の化骨に関するレ線学的研究, 日本レントダン学 会雑誌，16(1)，77，1938，29）松島千稳：氮管気管 支鏡検查上必要なる喉頭気管及び 気管支の触剖学的研 究, 医学研究, $13(8), 2135,1939.30)$ 藤田缼一:

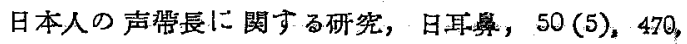
1944. 31）穆田普吉：知頭㳄骨の逐年的変化に関する

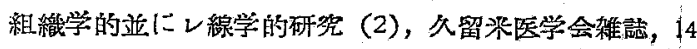
(7〜8), 305, 1951. 32) 樋口正德：喉頭蓋軟骨の北 熊学的研究，日本病理学会各誌，40 (総会最)，1951。

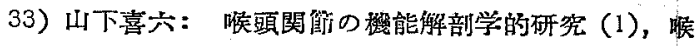
頭関煟の澫動，熊医会誌，27 (3〜 4), 83, 1953.

筆を擱くにめたり，終始愁第な御指遒と御校

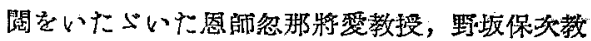
授に対して深謝する。

本完の姴旨は第 56 回九州医梯会医学会第 7 分科会，日本耳㐞咽喉科学会第58回総会，第 57 回无州医師会医学会第 9 万力科会, 第 7 回国際 気管食道科学会で発䘚した。

（原稿到着＝昭和 34.3 .1 日一急載） 